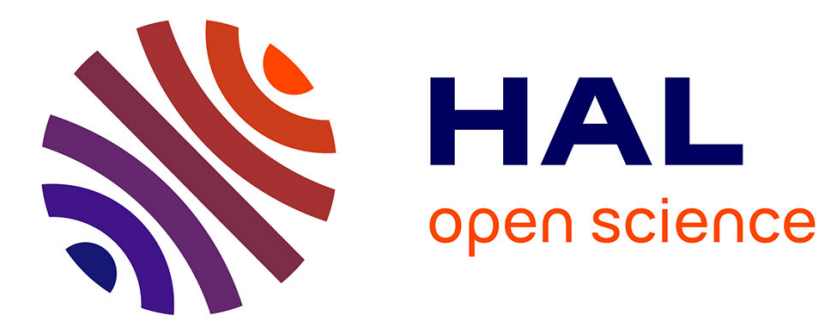

\title{
Sectoral and geographical positioning of the EU in the international division of labour
}

Angela Cheptea, Guillaume Gaulier, Dieudonné Sondjo, Soledad Zignago

\section{To cite this version:}

Angela Cheptea, Guillaume Gaulier, Dieudonné Sondjo, Soledad Zignago. Sectoral and geographical positioning of the EU in the international division of labour. [Technical Report] 2008. hal-02821174

\section{HAL Id: hal-02821174 \\ https://hal.inrae.fr/hal-02821174}

Submitted on 6 Jun 2020

HAL is a multi-disciplinary open access archive for the deposit and dissemination of scientific research documents, whether they are published or not. The documents may come from teaching and research institutions in France or abroad, or from public or private research centers.
L'archive ouverte pluridisciplinaire HAL, est destinée au dépôt et à la diffusion de documents scientifiques de niveau recherche, publiés ou non, émanant des établissements d'enseignement et de recherche français ou étrangers, des laboratoires publics ou privés. 


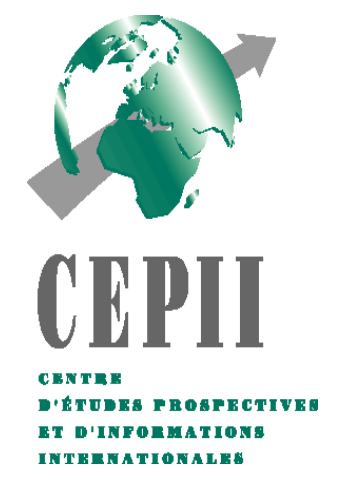

No $2008-02$ July

\section{Sectoral and Geographical Positioning of the EU in the International Division of Labour}

Angela Cheptea, Guillaume Gaulier, Dieudonné Sondjo,

Soledad Zignago 


\section{Sectoral and Geographical Positioning of the EU in the International Division of Labour}

Angela Cheptea

Guillaume Gaulier

Dieudonné Sondjo

Soledad Zignago

CEPII Report for the DG for Trade, European Commission

November 2006

Final report 2006-04-12

$\mathrm{N}^{\circ}$ Trade SPECIFIC CONTRACT No. SI2.424.313

implementing Framework Contract No TRADE/05/H3/01/1c 


\section{Contents}

\begin{tabular}{ll}
\hline 1. Introduction & 6 \\
\hline
\end{tabular}

2. Key Indicators for the Analysis of Exports Positioning of the EU and of its Main Trade Partners 8

2.1. The shift-share methodology applied to the growth of exports . . . . . . . . . . . 8

2.2. Revealed Comparative Advantages: The contribution to trade balance (CTB) indicator . . . . 11

3. The Overall Exports Positioning over the 1995-2003 Period 12

3.1. The Evolution of Market Shares _ . . . . . . . . . . . . . . . . . . . . . . . . . . 12

3.2. The Decomposition of Market Share Growth . . . . . . . . . . . . . . . . . . . . . . . . . 17

3.3. Adaptation Effects . . . . . . . . . . . . . . . . . . . . . . . . . 25

\begin{tabular}{|l|}
\hline 4. Sector Level Performance of Exports \\
\hline
\end{tabular}

5. Exports Performance on Up-market, Mid-market, and Low-market Products 30

5.1. The Classification of Products according to their Quality . . . . . . . . . . . . . . . 30

5.2. Exports Performance by Quality Range . . . . . . . . . . . . . . . . . . . . . . . 30

6. The Performance of Exported Products by the Level of Technology 34

6.1. The Definition of High-Tech Products . . . . . . . . . . . . . . . . . . . . . . 34

6.2. Exports Performance by Technology Level . . . . . . . . . . . . . . . . . . . . . . . . . . 35

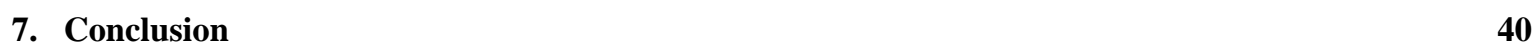

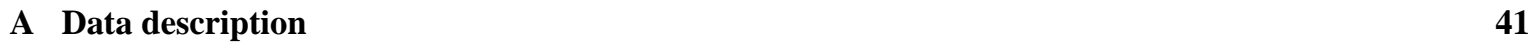

A1. The BACI database . . . . . . . . . . . . . . . . . . . . . . . . . . 41

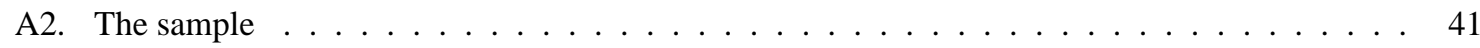

A3. Classification by Production Stages According To the BEC . . . . . . . . . . . . . . . . . . 42

\begin{tabular}{lll}
\hline B & Statistical Appendices & 43
\end{tabular} 
European Positioning in the International Division of Labour

European Positioning in the International Division of Labour

\section{SUMMARY}

Today's international trade in goods is driven mainly by the growth of exports and imports of the South. Emerging countries naturally gain global market shares in manufactured goods from old industrialised countries, including Europe. This trend has became even more pronounced during the last years. We use a detailed and exhaustive database on world trade from 1995 to 2003 to study the way in which the EU as a whole, and each of its 25 members individually faced these recent evolutions of the world market, compared to their main economic partners. For simplicity reasons, and because most European countries sell more and better on the domestic (EU) market, we disregard intra-EU trade flows.

Our analysis draws on a number economic indicators, including the evolution of market shares, adaptation effects, and the revealed comparative advantage, and on a shift-share decomposition of market share growth. First, we examine the overall evolution of countries' market shares, their geographical and sectoral specialisation, export performance, and capacity to adapt to changes in the global demand. Secondly, detailed results on the positioning and the performance of exports on different segments of the world market are produced. In both cases trade unit-values data is employed to separate the evolution of exports in monetary (value), and physical (volume) terms. This differentiation is necessary to distinguish between the impact of pure demand, and price-related factors on countries' exports performance. Unit values are used as well to segment markets according to the quality of traded products according to the principle that high-quality products (up-market) are also the more expensive ones. Nevertheless, besides intrinsic quality this taxonomy reflects additional aspects, such as trade-mark effects or the capacity of countries to sell their products at high prices.

EU's position on the global market has eroded during the last years, because of the poor performance of its largest members (except Germany), and despite the favourable sectoral breakdown of its exports. Still, its losses in market share were considerably smaller than those of its American and Japanese competitors, due mainly to the ability of European firms to sell expensive products to foreign consumers. The EU reinforced or acquired leadership in up-market products in a large number of industries, ranging from leather and clothing to machinery and automobiles. At the same time, European countries suffered important market share losses in the high-technology sector. Moreover, the revealed comparative advantage indicator shows that the EU, contrary to other developed countries, does not exhibit a specialisation in high-technology products. This result is explained by the large and deepening disadvantage of EU countries in down-market high-tech products, such as computer devices. Nevertheless, the EU has maintained and even reinforced its comparative advantage in up-market (high-price/high-quality) high-technology products. 
Cheptea, Gaulier, Sondjo and Zignago (2006), Study Report

PositionNement EUROPÉEN DANS LA DIVISION INTERNATIONALE DU TRAVAIL

\section{RÉSUMÉ}

Le commerce international des biens est mené à présent par la croissance des exportations et des importations du Sud. Les pays émergents gagnent naturellement des parts de marché sur les marchés des produits manufacturés de la part des pays industrialisés, y compris l'Europe. Cette tendance est devenue plus prononcée au cours des dernières années. Nous utilisons une base de données détaillée et exhaustive sur le commerce mondial de 1995 à 2003 pour étudier la manière dans laquelle l'UE dans son ensemble et chacun de ses 25 membres fait face à ces évolutions récentes du marché mondial, par rapport à leurs principaux partenaires économiques. Pour des raisons de simplicité, et parce que la plupart des pays de l'UE vendent plus et mieux sur le marché européen, nous excluons de l'analyse les flux commerciaux intra-UE.

Notre analyse est basée sur un nombre d'indicateurs économiques, tels que l'évolution des parts de marché, les effets d'adaptation et l'avantage comparatif révélé, et sur une décomposition shift-share de la croissance des parts de marché. Nous examinons d'abord l'évolution globale des parts de marché des pays, leur spécialisation géographique et sectorielle, performance à l'export et capacité d'adapter leur offre aux changements dans la demande mondiale. En suite, on présente des résultats détaillés sur le positionnement et la performance des pays sur des différents segments du marché mondial. Dans les deux cas, les données sur les valeurs unitaires des produits échangés sont utilisées pour séparer l'évolution des exportations exprimées en termes monétaires (en valeur) et en termes physiques (en volume). Cette distinction est nécessaire pour séparer l'impact pur de la demande et celui des facteurs liés au prix sur la capacité des pays d'exporter. On utilise les valeurs unitaires aussi pour segmenter les marchés en fonction de la qualité des biens commercés selon le principe que les produits de haute qualité (haut-de-gamme) sont également les plus chers. Néanmoins, à part la qualité, cette taxonomie reflète d'autres aspects, tels que l'effet de la marque ou la capacité des pays de vendre leurs produits à des prix élevés.

La position de l'UE sur le marché mondial s'est érodée pendant les dernières années en raison de la faible performance de ses grands membres (excepté l'Allemagne) et en dépit de la structure sectorielle favorable de ses exportations. Néanmoins, ses pertes de parts de marché ont été considérablement plus petites que celles subies par leurs concurrents américains et japonais, grâce principalement à la capacité des firmes européennes de vendre aux consommateurs étrangers des produits chers. L'UE a renforcé ou a acquis une position de leader sur les marchés des produits haut-de-gamme dans un grand nombre d'industries, allant du cuir et vêtements jusqu'aux machines et automobiles. En même temps, les pays européens ont perdu d'importants parts de marché dans le secteur de la haut technologie. L'indicateur d'avantage comparatif révélé montre même que l'UE, contrairement à d'autres pays développés, n'est pas spécialisée dans les produits intensifs en haut technologie. Ce résultat s'explique par le désavantage important et croissant de ses Etats membres dans les produits technologiques bas-de-gamme, tels que les composantes des ordinateurs. Néanmoins, l'UE a maintenu et même renforcé son avantage comparatif dans les produits technologiques haut-de-gamme. 


\title{
Sectoral and Geographical Positioning of the EU in the INTERNATIONAL DIVISION OF LABOUR
}

\author{
Angela CHEPTEA \\ Guillaume GAULIER \\ Dieudonné SONDJO \\ Soledad ZIGNAGO
}

\section{Introduction}

Today's international trade in goods is driven mainly by exports of the South. Moreover, the South is not just a supplier of the North but also a rapidly expanding market. As emerging economies, these countries are naturally winning shares of the world market for manufactured goods from the old industrialised countries, including Europe. This trend has, however, accelerated in the recent years, and has affected the domestic economy of developed countries. We use a detailed and exhaustive database on world trade over the 19952003 period to study the way in which the EU member countries faced this changing world market, compared to their main economic partners. We focus on the EU's external trade, leaving aside intra-EU trade flows, and examine a large range of segments of the world market. Our analysis draws on countries' market shares, structural demand effects, export performances, and comparative advantages.

We employ a marketshare approach to analyse the factors that determine the share of a country's exports in global imports of a given product. The evolution of this market share depends, on the one hand, on the sectoral and geographical structure of world demand and supply and, on the other hand, on the competitiveness of the country concerned. The positioning of countries from the North in the next decades could differ completely if trends continue at the rate observed since mid-1990s, or if they are reversed by the reaction of their governments in terms of economic policy 5 Thus in an expanding world market, Europe's share would normally collapse in the event of its technological slowdown and retreat from top technology markets, decline in the case of the marginalisation of EU's technological capacity, and stabilise in the event of an accelerated technological progress.

The method we use is based on a breakdown comparable to a constant market share analysis, with the difference that we prefer an econometric approach drawing on the great volume of information available in our world trade database, BACI (5000 products of the Harmonised System). From the trend in market shares, it is possible to discern the initial position held by exporters on their various markets (both sectoral and geographical), their capacity to adapt to changing conditions of world demand and, lastly, the competitiveness of exporters. Technically, the method consists first in decomposing annual growth rates into exporter, importer, and product fixed effects, which are employed afterwards for computing the structural and performance

\footnotetext{
${ }^{1}$ This is the final report 2006-04-12 $\mathrm{N}^{\circ}$ Trade SPECIFIC CONTRACT No. SI2.424.313 implementing Framework Contract No TRADE/05/H3/01/1c for the Commission of the European Union - Directorate-General for Trade. Support by the CIREM is gratefully acknowledged.

${ }^{2}$ INRA ESR - Rennes (Angela.Chepea@rennes.inra.fr).

${ }^{3}$ CEPII (guillaume.gaulier@gmail.com).

${ }^{4}$ CEPII (soledad.zignago@ cepii.fr).

${ }^{5}$ CEPII's report on the place of the European industry in the international division of labour (2004) develops six scenarios for Europe's manufacturing industry based on its technological positioning and the pace of institutional advances in the South.
} 
components of country level market share evolutions.

In a previous study (Cheptea, Gaulier and Zignago, 2005), we separate the performance effect in two adaptation effects, sectoral and geographical, and a competitiveness effects. The fact of carrying the analysis separately for each year, as well as the use of two-year average weights makes the computation of the adaptation irrelevant. Countries' adaptation to changing patterns of global demand is comprised partially in time-varying structural effects, both geographical and sectoral. Still, we compute here separately the adaptation effects. These indicators permit to evaluate the ability of countries to change their specialisation jointly with the dynamism of the global demand for different products.

Throughout the analysis we make an extensive use of trade unit-values. They provide us with information concerning two dimensions of trade flows: (i) the price/volume breakdown, and (ii) the quality breakdown. The availability of unit-values permits us to express concomitantly all trade flows in physical terms (in tons) and in value terms (in current USD). Secondly, we classify trade flows into three large quality ranges according to the principle that high quality (up-market) products are also the more expensive ones. Nevertheless, besides the intrinsic quality of traded goods, this taxonomy reflects additional aspects, such as trade-mark effects or the capacity of countries to sell their products at prices above the world average. In this context, the fact that most Chinese products are labelled low-market according to this classification may, indeed, not designate their true quality level but rather reflect the "made in China" effect. For example, the same computer component produced in China and Japan can be sold internationally at very different prices due to the large gap in wages in the two countries and, therefore, labelled differently in terms of quality level (In this case, the cheaper Chinese good will be considered as low-market, while the more expensive Japanese product will be classified as middle-market.)

Results in volume terms are more representative of countries' trade performances since they are not affected by changes in valuation due to exchange rates fluctuations (They include only the effect on trade volumes of changes in price competitiveness). Indeed, in most cases exchange rate variations are the main factor explaining the gap between the export performances expressed in value and in volume terms. For instance, when the US dollar appreciates against other major currencies, the dollar value of trade flows invoiced in those currencies (between Germany and Italy for instance) mechanically decreases. We make the distinction between values and volumes of goods traded internationally only in the case of the shift-share analysis. In the rest of the study we want to emphasize the segmentation of markets by quality (low-market, middle-market, up-market), and use trade flows expressed in value terms alone. In this case, unit-values are employed to segment the markets, rather than to assess the changes in prices.

According to recent works, industrialised countries will not be able to maintain a high level of per capita income in a highly globalised economy unless their products are sufficiently differentiated, especially in terms of quality, and possess a technological edge 6 Therefore, the current issues of international division of labour concern more the specific positioning of countries in terms of the quality and the technology of exported products than the main specialisation trends (between broadly defined industries). Furthermore, the vertical division of labour 7 and the associated outsourcing practices have different consequences to traditional specialisation. We examine these aspects in the present paper by analysing international trade in products by stages of production 8

The positioning of European countries on different markets is conditioned to a great extent by their specialisation in international trade, revealed by their comparative advantage. The revealed comparative advantage, in the light of the traditional theory of international trade, suggests that in a world where the required exchange-

\footnotetext{
${ }^{6}$ Feenstra \& Rose (2000), CEPII's report (2004).

${ }^{7}$ i.e. the fragmentation of valueadded chains: each country remains involved in a certain number of industries, but specialises in specific areas within these industries.

${ }^{8}$ The UN's Broad Economic Categories (BEC) nomenclature is employed.
} 
European Positioning in the International Division of Labour

rate adjustments have been made, each country has a structural advantage (smaller disadvantage) in certain sectors of economic activity and a disadvantage (smaller advantage) in others. It implies the examination of the difference between an observed and a theoretical trade coverage ratio, and can be computed as the contribution to the country's trade balance (CTB). Countries' structural advantages, linked to the resources or the technologies they possess, can be temporarily obscured by macroeconomic mismatches. For example, a US trade deficit in an industrial sector does not necessarily imply a disadvantage in that sector, given the country's large currentaccount deficit. We use the CTB indicator to analyse the specialisation of different countries.

\section{Key Indicators for the Analysis of Exports Positioning of the EU and of its Main Trade Partners}

\subsection{The shift-share methodology applied to the growth of exports}

A country's performance on the global market can be evaluated by the market shares it gains or losses. There are, however, several factors that contribute to the final outcome. One of the simplest and least expensive ways to investigate growth rates is the Shift-Share technique. Although employed mainly in regional studies on economic and employment growth, this method can be successfully extended to trade issues.

In the field of international trade, the traditional Shift-Share analysis aims to measure the consequences of geographical and sectoral specialisation on the growth of exports. A country's exports increase if it specializes in products with a growing world demand. To quantify the 'true' export performance of a country, one has to drop out the two specialisation effects. Technically, the change in a country $i$ 's exports during a time period $t$ is decomposed as the sum of the change in exports, associated to the global growth of world trade, the change induced by the growth of exports of individual products, the change arising from the growth of imports of specific markets, and a residual term specific to the exporting country:

$$
X_{i . .}^{t}-X_{i . .}^{t-1}=r X_{i . .}^{t-1}+\sum_{k}\left(r_{k}-r\right) X_{i . k}^{t-1}+\sum_{k} \sum_{j}\left(r_{j k}-r_{k}\right) X_{i j k}^{t-1}+\sum_{k} \sum_{j}\left(X_{i j k}^{t}-X\left(1+r_{j k}\right)\right)
$$

where $j$ denotes the partner, $k$ the product or sector, $r$ the global growth rate of exports for all countries in the sample except $i, r_{k}$ the global growth rate of product $k$ exports, and $r_{j k}$ the global growth rate of exports of product $k$ to country $j$.

This form of the shift-share decomposition introduces two major drawbacks. First, results are sensible to the order in which the two structure effects are considered: computing sectoral effects first and geographical effects afterwards and vice versa yields different results. Jayet (1993) suggests an alternative method that fixes this problem, and which has the advantage of providing standard errors for estimated effects. It consists in a weighted variance analysis of growth rates. We build our decomposition of exports' growth based on his methodology.

The other difficulty with the traditional shift-share analysis is that of disentangling volume evolutions from price evolutions. Indeed, the latter are greatly affected by exchange rate fluctuations, and are, therefore, of a less structural content than volume changes. The availability of both value and quantity trade statistics, permits us tackle this problem by applying the new decomposition methodology separately to quantities and to prices (unit-values: $P=U V=V / Q$ ).

The methodology employed in this paper is similar to the one developed by Cheptea, Gaulier and Zignago (2005). Differently form that study, the growth rate of country $i$ 's exports is computed as the change in the 
logarithm of the Tornqvist index of its exports:

$$
d \ln Q_{i}^{t}\left[=\ln \left(\frac{Q_{i}^{t}}{Q_{i}^{t-1}}\right)\right]=\sum_{k} \sum_{j} \frac{w_{i j k}^{t}}{w_{i}^{t}} d \ln Q_{i j k}^{t},
$$

where $Q$ stands for the volume of trade (expressed in tons), $V$ for the value of exports expressed in USD, $w_{i j k}=0.5\left(\frac{V_{i j k}^{t-1}}{V^{t-1}}+\frac{V_{i j k}^{t}}{V^{t}}\right)$, and $w_{i}^{t}=\sum_{k} \sum_{j} w_{i j k}^{t}$. Subscript $i$ indicates the country of origin (exporter), $j$ the country of destination, and $k$ the product or sector.

The Tornqvist index is a geometric mean index, with weights taking into account the value of trade in years $t$ and $t-1$, accounting in this way for structural changes. Diewert (1976) shows that the Tornqvist price index measures the change in a cost or expenditure function that has the translog functional form, and that the Tornqvist quantity index measures the change in a translog utility or production function. In these cases the Tornqvist index is best practice.

To compute country-level structural and performance effects, we estimate the growth rate of each elementary trade flow (from each exporter to every importer for a given product and a year) with country, partner and product fixed effects by weighted OLS:

$$
d \ln Q_{i j k}^{t}=\text { intercept }+\alpha_{i}^{t}+\beta_{j}^{t}+\gamma_{k}^{t}+\varepsilon_{i j k}^{t} .
$$

The growth of country $i$ exports can then be written as follows:

$$
d \ln Q_{i}^{t}=\text { intercept }+\hat{\alpha}_{i}^{t}+\sum_{j} \frac{w_{i j}^{t}}{w_{i}^{t}} \hat{\beta}_{j}^{t}+\sum_{k} \frac{w_{i k}^{t}}{w_{i}^{t}} \hat{\gamma}_{k}^{t},
$$

where hats indicate OLS-estimated coefficients in 3 (intercept is the constant estimated by the model).

In the estimations one group has to be removed for each set of fixed effects because of collinearity. Therefore, $\hat{\alpha}_{i}^{t}$ is a measure of country $i$ 'pure' exports growth relatively to the omitted country. A measure of country $i$ effect independent of the choice of the omitted country is given by the least square mean, obtained by adding the intercept and the weighted mean of partner and product effects to the estimated effect: ${ }^{9}$

$$
L S M E A N_{i}^{t}=\hat{\alpha}_{i}^{t}+\text { intercept }+\sum_{j} w_{j}^{t} \hat{\beta}_{j}^{t}+\sum_{k} w_{k}^{t} \hat{\gamma}_{k}^{t}
$$

For similar reasons, we normalise the estimated partner and product effects. The decomposition (4) can then be re-written as:

$$
d \ln Q_{i}^{t}=L S M E A N_{i}^{t}+\sum_{j} \frac{w_{i j}^{t}}{w_{i}^{t}} \tilde{\beta}_{j}^{t}+\sum_{k} \frac{w_{i k}^{t}}{w_{i}^{t}} \tilde{\gamma}_{k}^{t},
$$

where $\tilde{\beta}_{j}^{t}=\hat{\beta}_{j}^{t}-\sum_{j} w_{j}^{t} \hat{\beta}_{j}^{t}$ and $\tilde{\gamma}_{k}^{t}=\hat{\gamma}_{k}^{t}-\sum_{k} w_{k}^{t} \hat{\gamma}_{k}^{t}$.

Thus, we decompose the growth of each country's exports into three components: an exporter-effect $L S M E A N_{i}^{t}$, a geographic structure effect which depends on the destination of country $i$ exports, and a sectoral effect, which depends on the specialisation of its exports by sector or product. The first element represents also the country's exports performance.

\footnotetext{
${ }^{9}$ Note that $\sum_{j} w_{j}^{t}=\sum_{k} w_{k}^{t}=1$ and $\sum_{i} w_{i}^{t} L S M E A N_{i}^{t}=\sum_{i} \sum_{j} \sum_{k} w_{i j k}^{t} d \ln Q_{i j k}^{t}=d \ln Q^{t}$.
} 
The decomposition of trade growth is done separately for trade expressed in volume terms $\left(d \ln Q_{i}^{t}\right)$, and for the unitary value (price) of exported products $\left(d \ln P_{i}^{t}\right)$ for each year from 1995 to 2003 . The sum of the two gives the growth of trade expressed in value terms: $d \ln V_{i}^{t}=d \ln Q_{i}^{t}+d \ln P_{i}^{t}$. Thus, the growth of country $i$ export value (in USD) can be decomposed in two country effects (price and quantity), two geographical specialisation effects, and two sectoral specialisation effects. Results for the entire period are obtained by summing up the different effects across years.

Countries have no influence on structural effects, which result from the general growth of the markets where they export, both in terms of partners and sectors. The performance effect, on the contrary, indicates the degree to which the exporting country was able to gain or lose market shares. It is explained partially by the capacity of countries to adapt their sectoral and geographical specialisation, and partially by their price and non-price competitiveness.

Still, the methodology described above is not perfect. A first limit is that one can only consider flows for which both the traded value and quantity (weight) are available. However, this is not a severe limitation when data are harmonised (one partner declaring quantities is enough). Secondly, expressing quantities in tons may be an inadequate measure of volume for various products (e.g. electronics). Finally, new trade flows, quite large for emerging countries, are disregarded. The choice of measure units for trade in volume terms is restricted by limited data availability, while the issue of new flows is common to all shift-share approaches.

An additional dimension analysed by shift-share studies is the capacity of countries to adapt the geographical, respectively sectoral, structure of their exports to the changing patterns of global demand. Differently from studies using of a single decomposition for a number of years, the decomposition of trade growth rates for each year within the period, as in the present paper, does not permit to integrate adaptation effects ${ }^{10}$ In the latter case countries' adaptation is partially accounted for by the corresponding structural effects. Trade growth rates for the entire period are obtained then as the sum of annual growth rates, which are averages of growth rates of exporter-importer-product specific trade flows, different weights being used for each year. Similarly, the geographic and sectoral structure effects are computed as weighted sums of normalised annual partner and product fixed effects (see equation (4)). The adaptation effects are partially included in the decomposition through the use of different weights for each year.

Nevertheless, it may be useful to have a separate index of countries' adaptation to global demand. We choose to compute non-additive adaptation effects as the correlation coefficient between the average annual variation of the share of different products (partners) in each exporting country's trade and the product (partner) growth effect. The change in product (partner) shares for each country and product (partner) is given by the coefficient $\hat{b}_{i k}\left(\hat{b}_{i j}\right)$ on variable trend in the decomposition of annual shares expressed in logarithmic form into a constant term, a time or trend variable, and a residual disturbance term:

$$
\begin{aligned}
& d \ln \frac{V_{i k}^{t}}{V_{i}^{t}}=\text { intercept }+\hat{b}_{i k} \text { trend }{ }^{t}+\varepsilon_{i k}^{t} \\
& d \ln \frac{V_{i j}^{t}}{V_{i}^{t}}=\text { intercept }+\hat{b}_{i j} \text { trend }^{t}+\varepsilon_{i j}^{t}
\end{aligned}
$$

The variable trend in equations (7) and (8) takes integer values from 1 to 9 , corresponding to years in the considered time period, arranged in chronological order. Thus, trend ${ }^{t}$ is equal to 1 for $t=1995$, to 2 for $t=1996$, etc. The product (partner) growth effect for the entire period is obtained as the sum of annual

\footnotetext{
${ }^{10}$ In CEPII's report, 2004 and Cheptea, Gaulier and Zignago, 2005 the two adaptation effects are terms in the decomposition of period-specific growth rates.
} 
normalized product (partner) fixed effects in the decomposition of exports' growth given by $33: \gamma_{k}=\sum_{t} \hat{\gamma}_{k}^{t}$, respectively $\beta_{j}=\sum_{t} \hat{\beta}_{j}^{t}$. Adaptation effects are then computed as follows:

$$
\begin{gathered}
\text { Sectoral adaptation effect }=\operatorname{CORR}\left(\hat{b}_{i k}, \gamma_{k}\right) \\
\text { Geographical adaptation effect }=\operatorname{CORR}\left(\hat{b}_{i j}, \beta_{j}\right)
\end{gathered}
$$

It is straightforward that in this case adaptation effects are not expressed in terms of growth rates and, therefore, cannot be used as terms in the decomposition of exports or market share growth. Despite the similarity in terms of values with previous studies, adaptation effects as computed above should be used mainly for comparisons across countries (exporters).

\subsection{Revealed Comparative Advantages: The contribution to trade balance (CTB) indicator}

The comparative advantage is the building block of traditional trade theories, and derives from differences in pre-trade relative prices across countries. Uneven costs of traded products across countries, arising either from differences in technology (the Ricardian theory), or from differences in factor prices (the Heckscher-Ohlin theory), define a country's comparative advantages and disadvantages, and shape the pattern of international trade flows. The difficulty of measuring comparative advantages empirically consists in the fact that relative autarky prices are not observable. Balassa (1965) affirms that comparative advantages are "revealed" by observed trade patterns. Rather than determining the underlying sources of comparative advantage, he develops an index that identifies whether a country has a comparative advantage in a given sector / product. Since first introduces by Balassa (1965), the definition of relative comparative advantage has been revised and modified, such that an excessive number of measures exist today. Still, they all provide an answer to the same question: "Which are the strong and the weak points of an economy?"

Instead of relative export structures, as in the classic Balassa (1965) method, we opt for an analytical indicator based on the share of total trade balance, which also takes into account the size of each country's market. Thus, we compute first the trade balance for country $i$ and product $k$ relative to its total trade:

$$
y_{i k}=1000 * \frac{X_{i k}-M_{i k}}{X_{i .}+M_{i .}}
$$

$X$ and $M$ stand for country's exports and imports respectively.

Then, the contribution of product $k$ to the trade balance relative to total trade flows is defined as:

$$
f_{i k}=y_{i k}-g_{i k} * y_{i .},
$$

where $g_{i k}$ is the share of product $k$ in country $i$ 's trade, and $y_{i}$. is the overall trade balance of country $i$ :

$$
g_{i k}=\frac{X_{i k}+M_{i k}}{X_{i .}+M_{i .}} \text { and } y_{i .}=1000 * \frac{X_{i .}-M_{i}}{X_{i .}+M_{i}}
$$

Finally, we need to eliminate the impact of changes that are not specific to the country in question, but result from the evolution of the share of the product in world trade. To adjust trade flows with respect to a base year $\tau$, we multiply both exports $X_{i k}$ and imports $M_{i k}$ in each year $t \neq \tau$ by relative world weights $e_{k}^{t}=\frac{\left(X_{. k}^{\tau}+M_{. k}^{\tau}\right) /\left(X^{\tau}+M^{\tau}\right)}{\left(X_{. k}^{t}+M_{. k}^{t}\right) /\left(X_{. .}^{t}+M_{. .}^{t}\right)}$. The comparative advantage indicator $f_{i k}$ for year $\tau$ is identical to the one given 
by equation $(12)$. For all the other years $t \neq \tau$, the difference is greater the more world trade in product $k$ diverges from the average tendency for all commodities.

We compute comparative advantages for each exporter-product pair using the 6-digit HS classification of traded goods. Advantages at the level of industry, chain or stage of production are obtained by summing results across products within the particular industry, chain or stage.

\section{The Overall Exports Positioning over the 1995-2003 Period}

\subsection{The Evolution of Market Shares}

In 2003 the enlarged European Union accounted for $21.3 \%$ of world exports exclusive of intra-EU trade (Table 11. 11 Compared to other developed countries, Europe experienced a smaller erosion of its position on the world market during the 1995-2003 period (a 1.1 percentage point loss), but this shift was moderated by the increased economic size of the 10 countries that joined the union in May 2004. Among the "old" fifteen members only two managed to improve their positioning on the global market: Ireland (+0.4 p.p.), and Spain (+0.1 p.p.). This evolution was largely surpassed by losses registered by large European countries (France, Germany, Italy, UK).

Note, that an important part of disaggregated trade flows used to compute these figures appeared or vanished during the period. Thus, if one is to decompose the shifts in market share for each country into exporter, importer, and product specific effects, trade flows without equivalent in the previous or the following year are disregarded, and different figures for changes in market share are obtained. The last column of Table 1 displays changes in market share considering only importer-exporter-product trade flows for which annual growth rates can be computed. This method ignores newly created as well as disappearing trade flows. Thus, the 1.1 p.p. decrease in EU's overall market share is due to a large degree to the disappearance of certain country-partnerproduct trade flows. If one disregards these vanishing trade flows, EU members actually lost on the average only 0.5 p.p. of their market share.

Other countries of the Triad also reduced their global market shares on persisting trade flows and ceased to sell domestic goods in certain markets, but to a larger extend than the EU. This is concluded from larger market share losses obtained when all trade flows are included in computations (column 2 in Table 11). Meanwhile, developing countries have generally reinforced their position as global exporters. Of all countries China stands out with the most remarkable performance: it almost doubled its overall market share since 1995. An important part of this growth was due to new trade flows, both in terms of exported Chinese products and destination markets.

The export performance was uneven on different markets (Table 2). The EU global market share loss is the consequence of a weaker position of European exports on some large importing markets during the last decade. Still, the EU's share on many of these markets remains above its global share. The gain was the most prominent on the American market, where in 2003 the EU accounted for about one quarter of the foreign supply. This performance coincided with shrinking shares of Japanese and other Asian exports. The EU market share loss was minor on the declining Japanese market, and more prominent on the rapidly expanding Chinese market. In the case of the latter, only Germany and Ireland improved their exports position, while other large European countries reduced considerably their positions. The negative evolution of German and other large European countries' exports resulted into a large loss of EU market share (12 p.p.) on the Indian market, another promising market of the region. Differently from the above, the EU share remained considerably larger on the Brazilian and Russian markets. South America in general, and Brazil as the largest country of the region,

\footnotetext{
${ }^{11}$ The ten new EU member countries accounted only for $0.9 \%$ of this figure.
} 
is a historical trade partner of many European countries. The shares controlled by European exporting firms on this market, therefore, largely exceed those on the global market. In the case of the Russian market, beside the economic size and expected future growth, the proximity factor is particularly important in explaining the fact that more than a half of Russian imports originate from the EU. At country level, the majority of these trade flows come from Germany, Finland, and Italy, but former members of the communist block still account for a reasonably large share $(7.4 \%)$. 
Table 1: Market shares in 2003 and change over the 1995-2003 period, (in \% and p.p.)

\begin{tabular}{|c|c|c|c|}
\hline & $\begin{array}{l}\text { market share } \\
2003(\text { in } \%)\end{array}$ & $\begin{array}{l}\text { change in mar- } \\
\text { ket share between } \\
1995 \text { and } 2003 \\
\text { (in p.p.) }\end{array}$ & $\begin{array}{l}\text { change in market share between } \\
1995 \text { and } 2003 \text { for trade flows } \\
\text { for which trade growth can be } \\
\text { calculated (in p.p.) }\end{array}$ \\
\hline EU25 & 21.3 & -1.1 & -0.5 \\
\hline Austria & 0.6 & 0.0 & 0.1 \\
\hline Belgium and Lux. & 1.0 & 0.0 & -0.2 \\
\hline Cyprus & 0.0 & 0.0 & 0.0 \\
\hline Czech Republic & 0.2 & 0.0 & 0.0 \\
\hline Denmark & 0.5 & 0.0 & -0.1 \\
\hline Estonia & 0.0 & 0.0 & 0.0 \\
\hline Finland & 0.5 & 0.0 & 0.0 \\
\hline France & 2.7 & -0.3 & -0.4 \\
\hline Germany & 6.2 & -0.3 & 0.1 \\
\hline Greece & 0.1 & 0.0 & 0.0 \\
\hline Hungary & 0.2 & 0.1 & 0.1 \\
\hline Ireland & 0.8 & 0.4 & 0.4 \\
\hline Italy & 2.6 & -0.3 & -0.3 \\
\hline Latvia & 0.0 & 0.0 & 0.0 \\
\hline Lithuania & 0.0 & 0.0 & 0.0 \\
\hline Malta & 0.0 & 0.0 & 0.0 \\
\hline Netherlands & 1.1 & -0.4 & -0.1 \\
\hline Poland & 0.3 & 0.1 & 0.1 \\
\hline Portugal & 0.1 & 0.0 & 0.0 \\
\hline Slovakia & 0.1 & 0.0 & 0.0 \\
\hline Slovenia & 0.1 & 0.0 & 0.0 \\
\hline Spain & 0.9 & 0.1 & 0.0 \\
\hline Sweden & 0.9 & -0.1 & -0.2 \\
\hline United Kingdom & 2.4 & -0.4 & -0.5 \\
\hline Japan & 10.5 & -4.0 & -2.4 \\
\hline Korea & 4.4 & 0.3 & 0.4 \\
\hline Russia & 1.4 & 0.3 & -0.4 \\
\hline India & 1.2 & 0.2 & 0.3 \\
\hline Ukraine & 0.3 & 0.2 & -0.1 \\
\hline USA & 13.8 & -2.7 & -1.6 \\
\hline Chinese world & 15.7 & 5.5 & 4.8 \\
\hline China & 11.2 & 5.1 & 4.3 \\
\hline Hong Kong & 1.8 & 0.5 & 0.5 \\
\hline Mediterranean & 1.7 & 0.3 & 0.4 \\
\hline GCC & 0.6 & 0.1 & 0.3 \\
\hline Mercosur & 2.2 & -0.1 & -0.1 \\
\hline Brazil & 1.6 & 0.0 & 0.1 \\
\hline ASEAN & 8.3 & 0.2 & -0.3 \\
\hline RoW & 18.6 & 0.6 & -0.7 \\
\hline All & 100 & 0 & 0 \\
\hline
\end{tabular}


Table 2: Market shares on main markets in 2003 and change over the 1995-2003 period, (in \% and p.p.)

\begin{tabular}{|c|c|c|c|c|c|c|}
\hline & \multicolumn{2}{|c|}{ USA } & \multicolumn{2}{|c|}{ Japan } & \multicolumn{2}{|c|}{ China } \\
\hline & 2003 (in \%) & $\Delta$ (p.p.) & 2003 (in \%) & $\Delta$ (p.p.) & 2003 (in \%) & $\Delta$ (p.p.) \\
\hline EU25 & 23.4 & 2.0 & 18.2 & -0.7 & 15.7 & -2.4 \\
\hline Austria & 0.5 & 0.2 & 0.4 & 0.0 & 0.4 & -0.1 \\
\hline Belgium and Lux. & 0.8 & 0.1 & 0.8 & 0.1 & 0.8 & -0.2 \\
\hline Cyprus & 0.0 & 0.0 & 0.0 & 0.0 & 0.0 & 0.0 \\
\hline Czech Republic & 0.1 & 0.1 & 0.1 & 0.0 & 0.1 & 0.0 \\
\hline Denmark & 0.4 & 0.0 & 0.9 & 0.1 & 0.3 & 0.0 \\
\hline Estonia & 0.0 & 0.0 & 0.0 & 0.0 & 0.0 & 0.0 \\
\hline Finland & 0.4 & 0.0 & 0.5 & 0.0 & 0.5 & -0.1 \\
\hline France & 2.6 & -0.2 & 2.3 & 0.1 & 1.8 & -0.8 \\
\hline Germany & 7.1 & 0.7 & 5.4 & -0.3 & 6.8 & 0.8 \\
\hline Greece & 0.1 & 0.0 & 0.0 & 0.0 & 0.0 & 0.0 \\
\hline Hungary & 0.2 & 0.1 & 0.2 & 0.1 & 0.1 & 0.0 \\
\hline Ireland & 2.0 & 1.3 & 1.3 & 0.5 & 0.2 & 0.2 \\
\hline Italy & 2.4 & -0.3 & 2.0 & -0.3 & 1.5 & -1.1 \\
\hline Latvia & 0.0 & 0.0 & 0.0 & 0.0 & 0.0 & 0.0 \\
\hline Lithuania & 0.0 & 0.0 & 0.0 & 0.0 & 0.0 & 0.0 \\
\hline Malta & 0.0 & 0.0 & 0.0 & 0.0 & 0.0 & 0.0 \\
\hline Netherlands & 0.9 & -0.1 & 0.8 & -0.1 & 0.6 & -0.1 \\
\hline Poland & 0.1 & 0.0 & 0.1 & 0.0 & 0.1 & 0.0 \\
\hline Portugal & 0.2 & 0.0 & 0.1 & 0.0 & 0.1 & 0.0 \\
\hline Slovakia & 0.1 & 0.1 & 0.0 & 0.0 & 0.1 & 0.0 \\
\hline Slovenia & 0.1 & 0.0 & 0.0 & 0.0 & 0.0 & 0.0 \\
\hline Spain & 0.6 & 0.0 & 0.4 & -0.1 & 0.5 & -0.4 \\
\hline Sweden & 1.1 & 0.0 & 0.8 & -0.3 & 0.8 & -0.3 \\
\hline United Kingdom & 3.6 & -0.1 & 2.3 & -0.5 & 1.1 & -0.3 \\
\hline Japan & 11.7 & -7.5 & & & 17.7 & -3.5 \\
\hline Korea & 3.8 & -0.3 & 5.9 & -1.0 & 11.1 & 3.1 \\
\hline Russia & 0.5 & 0.0 & 1.1 & -0.3 & 2.2 & -0.4 \\
\hline India & 0.9 & 0.2 & 0.5 & -0.1 & 0.9 & 0.6 \\
\hline Ukraine & 0.0 & 0.0 & 0.0 & 0.0 & 0.3 & 0.0 \\
\hline USA & & & 20.2 & -1.0 & 8.5 & -3.0 \\
\hline Chinese world & 14.6 & 4.8 & 29.3 & 10.7 & 18.3 & -0.9 \\
\hline China & 11.6 & 5.8 & 24.7 & 12.2 & & \\
\hline Hong Kong & 1.1 & -0.2 & 0.7 & 0.0 & 6.4 & -0.6 \\
\hline Mediterranean & 0.5 & 0.1 & 0.2 & -0.1 & 0.2 & 0.0 \\
\hline GCC & 0.2 & 0.0 & 0.2 & -0.1 & 0.5 & 0.0 \\
\hline Mercosur & 1.9 & 0.0 & 0.9 & -0.5 & 2.2 & 0.6 \\
\hline Brazil & 1.6 & 0.1 & 0.7 & -0.4 & 1.3 & 0.2 \\
\hline ASEAN & 6.8 & -0.9 & 14.6 & 0.9 & 8.6 & 1.7 \\
\hline RoW & 35.8 & 1.7 & 10.0 & -2.9 & 13.8 & 4.1 \\
\hline All & 100 & 0 & 100 & 0 & 100 & 0 \\
\hline
\end{tabular}


European Positioning in the International Division of Labour

Table 2: Market shares on main markets in 2003 and change over the 1995-2003 period, (in \% and p.p.) (continued)

\begin{tabular}{|c|c|c|c|c|c|c|}
\hline & \multicolumn{2}{|c|}{ India } & \multicolumn{2}{|c|}{ Brazil } & \multicolumn{2}{|c|}{ Russia } \\
\hline & 2003 (in \%) & $\Delta$ (p.p.) & 2003 (in \%) & $\Delta$ (p.p.) & 2003 (in \%) & $\Delta$ (p.p.) \\
\hline EU25 & 23.0 & -11.8 & 32.8 & 0.7 & 55.5 & -10.8 \\
\hline Austria & 0.5 & 0.0 & 0.7 & 0.2 & 1.7 & -0.5 \\
\hline Belgium and Lux. & 1.4 & -0.2 & 1.6 & -0.3 & 2.0 & -0.8 \\
\hline Cyprus & 0.0 & 0.0 & 0.0 & 0.0 & 0.0 & 0.0 \\
\hline Czech Republic & 0.3 & -0.1 & 0.2 & 0.1 & 0.9 & -0.7 \\
\hline Denmark & 0.5 & -1.1 & 0.5 & 0.0 & 1.1 & -0.6 \\
\hline Estonia & 0.0 & 0.0 & 0.0 & 0.0 & 0.8 & 0.0 \\
\hline Finland & 0.5 & -0.3 & 0.7 & 0.2 & 5.0 & 0.0 \\
\hline France & 2.5 & -1.1 & 4.2 & 1.1 & 4.6 & 0.1 \\
\hline Germany & 6.2 & -5.6 & 11.3 & 0.3 & 18.1 & 0.2 \\
\hline Greece & 0.1 & 0.0 & 0.1 & 0.0 & 0.3 & -0.4 \\
\hline Hungary & 0.1 & 0.0 & 0.2 & 0.1 & 1.0 & -1.2 \\
\hline Ireland & 0.3 & 0.2 & 0.5 & 0.3 & 0.4 & -0.6 \\
\hline Italy & 2.5 & -1.4 & 4.3 & -2.1 & 5.4 & -2.5 \\
\hline Latvia & 0.0 & 0.0 & 0.0 & 0.0 & 0.3 & -0.6 \\
\hline Lithuania & 0.0 & 0.0 & 0.0 & 0.0 & 0.9 & -0.4 \\
\hline Malta & 0.0 & 0.0 & 0.1 & 0.1 & 0.0 & 0.0 \\
\hline Netherlands & 1.2 & -0.7 & 1.3 & -1.0 & 3.4 & -0.9 \\
\hline Poland & 0.2 & -0.2 & 0.3 & 0.2 & 2.4 & -1.0 \\
\hline Portugal & 0.0 & 0.0 & 0.3 & 0.0 & 0.1 & -0.1 \\
\hline Slovakia & 0.1 & -0.2 & 0.0 & 0.0 & 0.4 & -0.5 \\
\hline Slovenia & 0.1 & 0.0 & 0.0 & 0.0 & 0.6 & -0.2 \\
\hline Spain & 0.6 & -0.3 & 2.2 & 0.3 & 1.4 & 0.3 \\
\hline Sweden & 1.7 & 0.5 & 1.5 & 0.2 & 2.0 & 0.3 \\
\hline United Kingdom & 4.1 & -1.6 & 2.9 & 0.9 & 2.8 & -0.8 \\
\hline Japan & 5.0 & -4.4 & 5.6 & 0.0 & 2.8 & -0.3 \\
\hline Korea & 6.4 & 2.1 & 2.7 & -0.3 & 2.4 & -1.3 \\
\hline Russia & 3.8 & 1.1 & 1.0 & 0.6 & & \\
\hline India & & & 0.7 & 0.4 & 1.0 & -1.6 \\
\hline Ukraine & 0.4 & -0.7 & & & 6.0 & \\
\hline USA & 8.7 & -3.0 & 23.1 & -1.1 & 4.1 & -1.4 \\
\hline Chinese world & 10.3 & 5.6 & 6.3 & 2.7 & 6.9 & 2.4 \\
\hline China & 7.1 & 4.4 & 4.5 & 3.6 & 6.4 & 1.9 \\
\hline Hong Kong & 1.8 & 1.1 & 0.6 & -0.9 & 0.2 & 0.2 \\
\hline Mediterranean & 1.0 & -1.1 & 0.8 & 0.6 & 1.9 & -2.0 \\
\hline GCC & 3.9 & 0.0 & 0.0 & 0.0 & 0.0 & -0.0 \\
\hline Mercosur & 1.9 & -0.1 & 13.1 & -2.5 & 2.7 & 0.8 \\
\hline Brazil & 0.7 & -0.6 & & & 2.3 & 0.7 \\
\hline ASEAN & 13.8 & 3.5 & 2.5 & 0.1 & 1.5 & -2.0 \\
\hline RoW & 21.8 & 9.0 & 10.4 & -1.0 & 15.2 & 10.1 \\
\hline All & 100 & 0 & 100 & 0 & 100 & 0 \\
\hline
\end{tabular}


The redistribution of market shares leads to a structural change in the competition faced by European products abroad. As can be seen from Table 2, European exports are less exposed to the competition from American and Japanese products, and increasingly to that from Chinese and other developing countries' goods.

\subsection{The Decomposition of Market Share Growth}

As a next step, we decompose the average market share growth of each exporter on individual products and markets using the shift-share analysis described in details in section 2.1. The explained variable is expressed in percent of the 1995 market share. The equivalent change in market share expressed in percentage points is shown in the last column of Table 1. Thus, given the share of EU25 in global exports in 2003 equal to 21.3\%, its 0.5 p.p. loss of market share corresponds to a $2.4 \%[=(-0.5 /(21.3-(-0.5)) * 100)]$ loss of exports in value terms. We decompose each country's market share growth in three terms: the country's export performance, the geographical structure of its exports, and the product-level composition of its exports. The impact of these three factors explains the total evolution of exporter's market share. A country can gain global market share by exporting its goods to partners with a growing import demand, by selling to foreign partners products characterised by an expending global demand, or by improving its export performance. The first two effects reflect the dynamics of country's initial specialisation, and are unaffected by its actions and policies within the considered period (year). On the contrary, countries can upgrade their export performance by improving the price and non-price competitiveness of their products, by adapting the sectoral and geographical breakdown of their exports to changes in global demand. Technically, the decomposition of market share growths is done separately for each year from 1995 to 2003 and each elementary (country-partner-product) trade flow. Country-level structure and performance components are computed only afterwards, with two-year average weights. Results, displayed in Table 3, permit to evaluate how the Triad reacted to the emergence of new competitors in the world markets.

The above world average growth rates of exports from countries in the South led to an important increase of their market shares by the year 2003. Undoubtedly, this evolution was in the detriment of the group of industrialised countries. The EU market share eroded during the last years due to the poor performances of its largest members, except Germany, who showed a better resistance. The $2.4 \%$ loss in global market share for Europe was considerably smaller than the $13.5 \%$ and $31.5 \%$ decline for American and respectively Japanese exports. This outcome is the a result of the better performance of European firms, consisting mainly in their ability to sell expensive products to foreign consumers. The advantageous geographical orientation of American exports due to the expanding Mexican market situated just across the border and the increased trade integration within the NAFTA, as well as the large specialisation in products and sectors that were increasingly traded internationally prevented the US from experiencing an even larger market share loss during the last decade. By 2003 Japan, with a less favourable structure of exports, both in terms of trade partners and exported products, lost about one third of its 1995 global share.

The decline of the EU share in the global market was considerably larger in volume terms. This gap cannot be explained by changes in the nominal exchange rate of the European currency. Indeed, between 1995 and 2003 the ECU/euro depreciated by 6\% against the US dollar (Figure 1). Thus, the increase of prices of European products relative to the world average was not caused by changes in exchange rates. Note, that the upgrade of products exported by the new EU members is only part of the story. As explained in section 2.1. the difference between the market share growth expressed in value terms and the one expressed in volume terms, both displayed in Table 3 . reflects the evolution of prices on exported goods relative to the world average. Thus, a larger market share growth or a smaller market share loss in value terms observed for most EU15 countries testifies of an above world average increase in the price of exported products between 1995 and 2003. As 
Table 3: Decomposition of market share growth, Total trade (in \%)

\begin{tabular}{|c|c|c|c|c|c|c|c|c|}
\hline & \multicolumn{4}{|c|}{ Volume } & \multicolumn{4}{|c|}{ Value } \\
\hline & $\begin{array}{l}\text { market } \\
\text { share } \\
\text { growth }\end{array}$ & $\begin{array}{l}\text { exports } \\
\text { perform. }\end{array}$ & $\begin{array}{l}\text { geo. } \\
\text { structure } \\
\text { effect }\end{array}$ & $\begin{array}{l}\text { sectoral } \\
\text { structure } \\
\text { effect }\end{array}$ & $\begin{array}{l}\text { market } \\
\text { share } \\
\text { growth }\end{array}$ & $\begin{array}{l}\text { exports } \\
\text { perform. }\end{array}$ & $\begin{array}{l}\text { geo. } \\
\text { structure } \\
\text { effect }\end{array}$ & $\begin{array}{l}\text { sectoral } \\
\text { structure } \\
\text { effect }\end{array}$ \\
\hline EU25 & -15.2 & -21.1 & -2.4 & 8.3 & -2.4 & -12.9 & -1.6 & 12.1 \\
\hline EU15 & -16.8 & -22.9 & -2.7 & 8.8 & -4.2 & -15.0 & -1.9 & 12.7 \\
\hline Austria & 9.6 & 5.7 & -0.5 & 4.4 & 14.9 & 6.5 & 0.9 & 7.5 \\
\hline Belgium \& Lux. & -23.6 & -25.7 & -2.2 & 4.3 & -16.3 & -25.3 & -1.2 & 10.3 \\
\hline Cyprus & 56.2 & 103.8 & -4.2 & -43.4 & 205.5 & 207.6 & -3.5 & 1.5 \\
\hline Czech Rep. & -11.2 & -3.4 & 3.6 & -11.5 & 32.3 & 35.0 & 4.4 & -7.0 \\
\hline Denmark & -30.7 & -35.9 & -9.1 & 14.3 & -21.1 & -28.2 & -5.9 & 13.0 \\
\hline Estonia & 89.3 & 122.7 & -10.6 & -22.8 & 50.2 & 79.1 & -11.4 & -17.5 \\
\hline Finland & 6.9 & -2.5 & -5.6 & 15.0 & 5.8 & -4.8 & -3.8 & 14.3 \\
\hline France & -25.7 & -35.3 & -2.9 & 12.5 & -12.0 & -26.7 & -2.4 & 17.1 \\
\hline Germany & -4.1 & -14.1 & -0.2 & 10.2 & 1.6 & -13.6 & 0.1 & 15.1 \\
\hline Greece & -30.5 & -22.9 & 15.8 & -23.5 & -11.4 & -5.2 & 13.3 & -19.4 \\
\hline Hungary & 15.6 & 2.9 & 12.3 & 0.4 & 41.7 & 33.9 & 11.9 & -4.1 \\
\hline Ireland & 11.6 & -7.3 & -9.5 & 28.4 & 92.6 & 53.9 & -7.9 & 46.6 \\
\hline Italy & -26.5 & -21.8 & -1.2 & -3.4 & -11.9 & -5.6 & -0.6 & -5.8 \\
\hline Latvia & -61.6 & -32.5 & -11.1 & -18.1 & -67.9 & -41.7 & -11.2 & -15.0 \\
\hline Lithuania & 7.2 & 36.1 & -12.2 & -16.7 & -1.0 & 27.8 & -11.1 & -17.8 \\
\hline Malta & 144.8 & 91.0 & 2.6 & 51.2 & 173.4 & 130.4 & 5.0 & 38.0 \\
\hline Netherlands & -22.1 & -21.2 & -5.9 & 5.0 & -8.7 & -14.2 & -3.9 & 9.5 \\
\hline Poland & 39.0 & 54.1 & -2.9 & -12.2 & 43.7 & 60.3 & -1.3 & -15.3 \\
\hline Portugal & -17.9 & -11.7 & 2.0 & -8.2 & -11.6 & -6.2 & 3.2 & -8.6 \\
\hline Slovakia & 115.1 & 127.9 & 3.7 & -16.5 & 135.5 & 144.8 & 4.3 & -13.6 \\
\hline Slovenia & 9.6 & -24.3 & 26.3 & 7.6 & 17.6 & -14.5 & 22.4 & 9.8 \\
\hline Spain & -9.3 & -4.0 & 0.9 & -6.1 & -0.4 & 9.5 & -3.9 & -6.0 \\
\hline Sweden & -33.8 & -48.2 & -3.6 & 18.0 & -14.3 & -34.0 & -2.6 & 22.4 \\
\hline$U K$ & -30.9 & -36.9 & -7.2 & 13.3 & -16.7 & -31.0 & -4.6 & 18.9 \\
\hline USA & -3.0 & -43.0 & 27.6 & 12.4 & -13.5 & -38.6 & 8.8 & 16.4 \\
\hline Japan & -35.2 & -40.9 & -5.9 & 11.6 & -31.5 & -43.5 & 0.0 & 12.0 \\
\hline China & 63.1 & 114.8 & -21.5 & -30.1 & 66.0 & 116.2 & -16.0 & -34.2 \\
\hline Brazil & 13.4 & 42.1 & -9.8 & -18.8 & 6.9 & 41.1 & -9.8 & -24.4 \\
\hline Russia & -49.6 & -27.3 & 5.0 & -27.4 & -41.7 & -23.3 & 13.9 & -32.3 \\
\hline India & 25.2 & 59.9 & -2.6 & -32.1 & 19.2 & 54.6 & 0.3 & -35.7 \\
\hline
\end{tabular}

Note: Energy, wastes, and some minor non-manufacturing sectors are excluded (see Appendix A2. Figures are approximate values of growth rates, since they are obtained as changes in natural logarithm, multiplied by 100 . The 'market share growth' computed with logarithm is the sum of export performance and the two structural effects. 
Figure 1: Evolution of the annual change in nominal exchange rate of main currencies against the US dollar

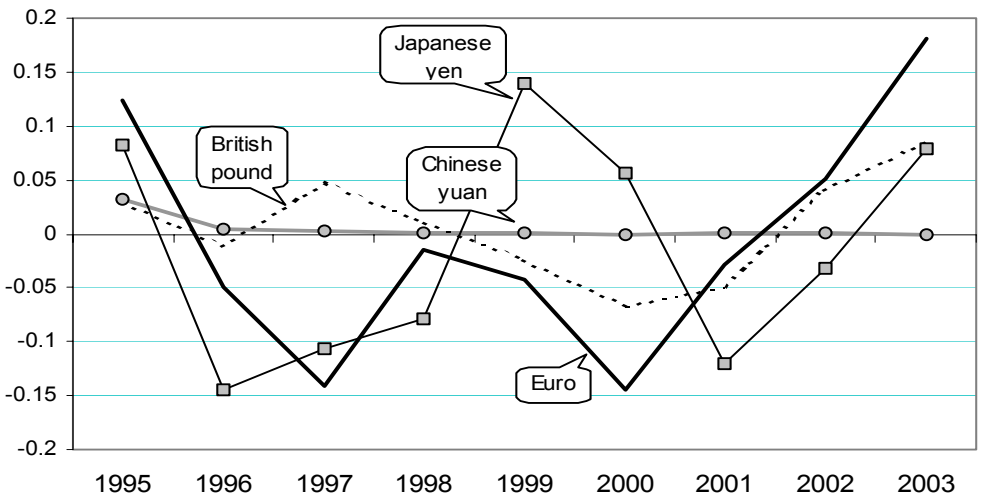

shown later in the study, this shift of European exports towards more expensive products can be attributed to the increase in the share of higher quality goods (middle- and up-market products) in EU's exports.

In volume terms, EU is situated midway between the stable position of American exports and the collapse of Japanese market shares. The US maintained their volume market share thanks to increasing exports to Mexico, reflected in their large positive geographical effect (27.6\%). Indeed, given the concentration of Mexican foreign trade with its northern neighbour, the creation of NAFTA is a very important factor of the US trade performance. Contrary to European and Japanese exports, the price of exported American products declined between 1995 and 2003.

The EU trade performance displayed in Table 3 is lower than the one found by similar studies. This gap arises from two major differences in the methodology. First, we disregard intra-EU trade since most member countries enjoy a better positioning on the EU market (see Table 20 of Appendix B). This limit is imposed because the aim of the present study is to evaluate the performance of EU exports on foreign markets. Secondly, we compute country-level market share growth from growth rates computed on elementary trade flows at a very disaggregated level (using the 6-digit HS classification of traded products). Thus we ignore trade flows appearing and disappearing throughout the considered time period. We argue that this approach is to be preferred to the computation of trade growth directly at aggregated levels since the largest part of appearing and disappearing trade flows are due to the fact that countries do not declare their international trade statistics in all years. Thus, if growth rates are computed at aggregate level, a trade flow declared at time $t+1$ but not at $t$ will count as a newly created flow and will artificially inflate growth rates. Our method corrects for these problems as such trade flows are dropped out. Obviously, true new flows are eliminated as well, but this should only slightly under-evaluate international trade since such trade flows exist and are accounted for in the following years. An additional limit on trade flows used to compute market share growth rates is imposed by the unavailability of data on physical units of traded products, necessary for the computation of trade flows in volume terms. Thus, the decomposition of market share growth yields an important reduction of the data sample employed: depending on the year between 16\% (in 1997) and 27\% (in 2003) of global trade flows are disregarded.

Sectoral effects in the above decomposition are positive for the EU, as for the majority of industrialised countries in the world. This reflects the specialisation of the North in sectors characterised by a high growth rate of international trade. In the absence of a negative export performance and/or geographical structure 
effect, these countries could have even gained shares on the global market. Still, figures vary considerably across EU countries. In the case of Italy, Spain, Portugal, and Greece, as well as most of new members, the sectoral structure slowed down the growth of exports. On the contrary, the geographical orientation of European exports was rather unfavourable and generated market share losses. With several notable exceptions, industrialised countries targeted mainly consumption markets whose imports grew at a slower pace than the world average. In this context, the US benefited from the best geographical structure of exports, owed much to the rapid expansion of the Mexican market.

Still, the loss in market share experienced by the EU was driven mainly by the decline in its exports performance. The latter corresponds to a great extend to the increase in the price of European products relative to other countries. Only in the last part of the period can this evolution be attributed to the appreciation of the Euro: by $23 \%$ in 2002-2003. Again, the difference between old and new member countries is very pronounced. The majority of new members recorded a large positive performance and a market share gain but, given their small economic size, their accession to the Union has only marginally improved these indicators. (Note the very small differences between figures for EU25 and EU15 in Table 3 )

At the same time, large emerging countries (China, Brazil, India, and Mexico) continue to acquire market shares despite the fact that they were disadvantaged by both the sectoral and the geographical breakdown of their exports. Evolutions for these countries were very similar in value and volume terms.

The shift-share method employed in this study computes country-specific structural effects for each separate year within the considered period with different (varying in the time) weights. Therefore, the ability of different countries to adapt their exports to changes on the demand side is partially reflected by the evolution of their sectoral and geographical structure effects. The gain in market share induced by the concentration of exports in sectors with the highest trade growth rates was very similar and steady for the Europe and the US (Figure 2). By the end of 2003 it amounted to slightly above 2\% for both. The Japanese sectoral effect, although marked by more ample fluctuations, was close to $1 \%$. The amplitude of year-to-year changes was significantly larger for the emerging economies. Contrary to other countries from the South, which were better off by the end of the period, China suffered a degradation of its exports sectoral structure. This is partly due to the favourable evolution of trade in primary products, which account for an important share of South's but not Chinese exports.

In order to illustrate the sectoral structure effect, we plot separately its evolution for two European countries with similar specialisation, Finland and Sweden, and add Germany as reference (second graph in Figure 2). The evolution of the sectoral structure effect is similar in the two Nordic countries. Their specialisation in cellular phones (Nokia and Ericsson) boosted their exports in 1999, 2000 and 2003, but had a more neutral contribution following the burst of the ICT bubble in 2001-2002. Compared to Germany, the two countries have a much more volatile sectoral structure effect. This is another consequence of their specialisation in communication devices. The main difference between Finland and Sweden is the specialisation of the latter as well in vehicles. This industry being also a stronghold for Germany, explains the fact that Sweden's sectoral structure effect lies between those of Germany and Finland.

Structural effects for three EU members having distinct sectoral specialisation are plotted together in the last part of Figure 2. Germany and Italy have in common a specialisation in professional goods (mechanic) favourable to the growth of their exports, but Italy "suffers" from its strong positioning in the apparel industry. Before 2002, Polish's specialisation in food industry, tobacco and textile was detrimental to its export growth, but the change to more sophisticated goods (machinery, transport equipment) is visible in its 2003 exports structure.

A country's reactions to uneven imports growth rates of its partners are captured to a certain extend by variations in the geographical structure effect. Nevertheless, since the modification of the exports structure requires a lot of time, the evolution of structural effects reproduces mainly changes in the demand for products accounting for the largest share of a country's exports and changes in import trends of its main trading partners. 
Figure 2: Evolution of the sectoral structure effect, (in \%, trade growth in volume terms)
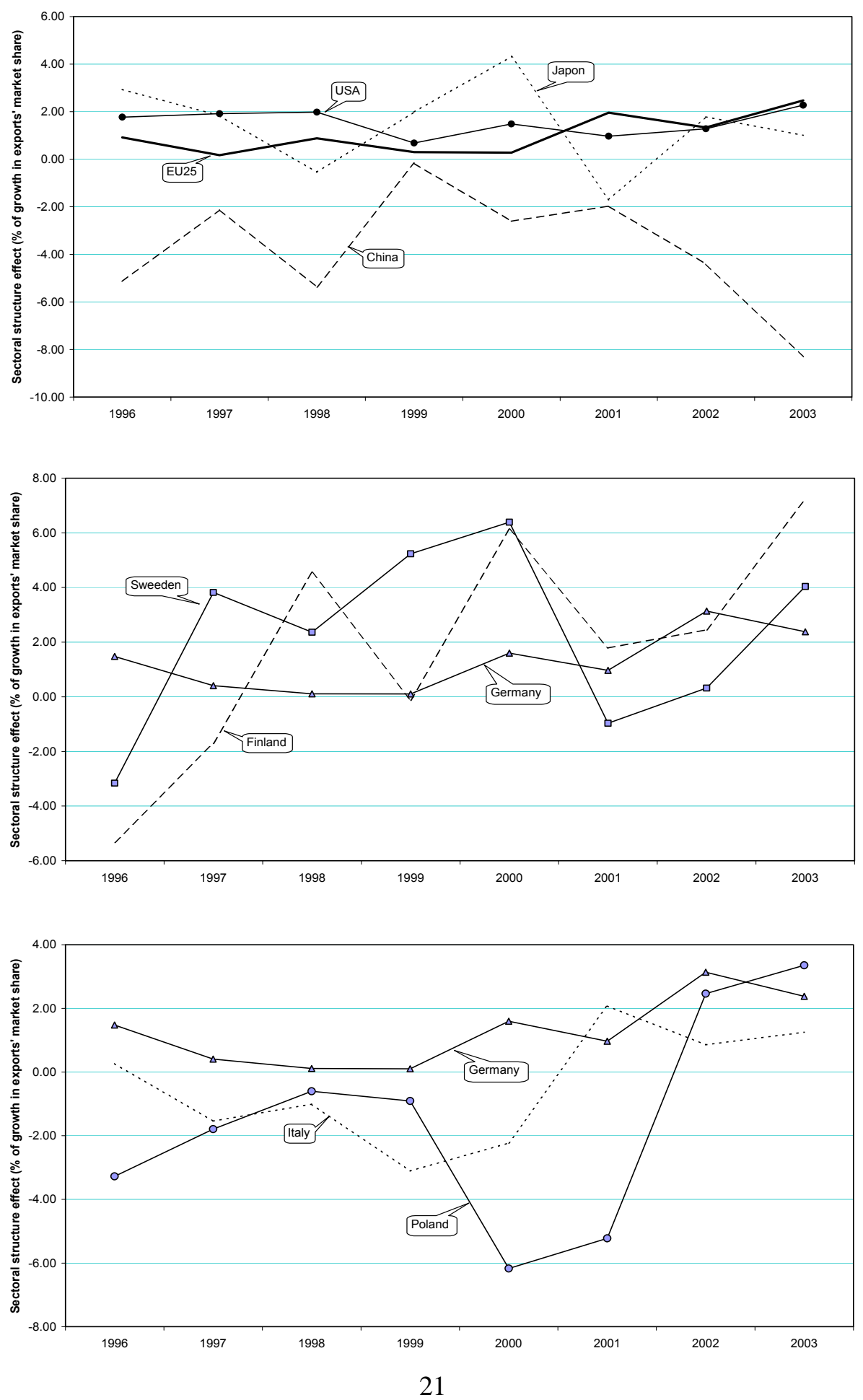
Figure 3: Evolution of the geographical structure effect, (in \%, trade growth in volume terms)
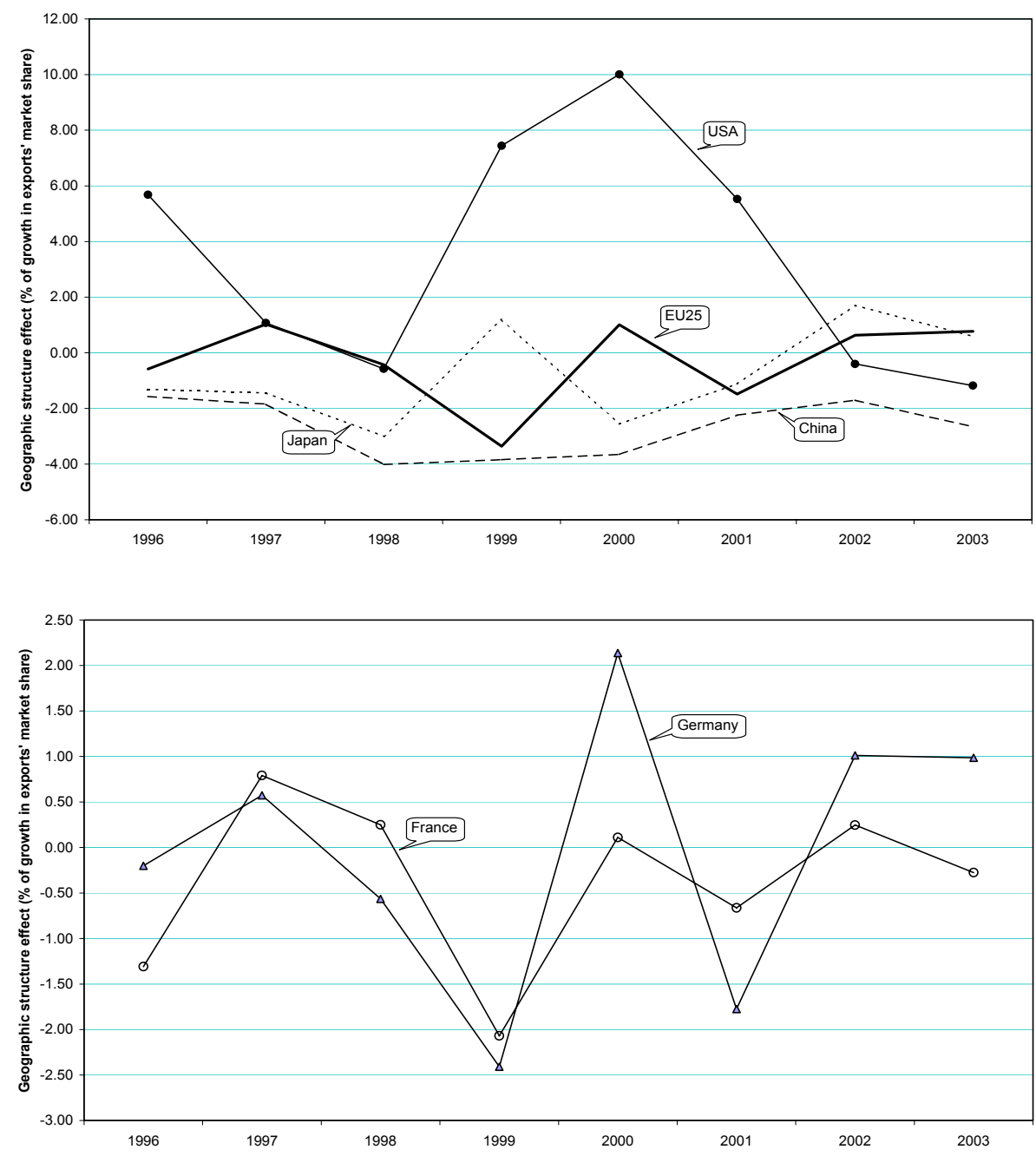

Thus, the reversed U-shape for the US (Figure 3) corresponds to the spectacular increase of Mexican imports since the creation of NAFTA. Similarly, the erosion of geographical structures for most countries during the 1997-1998 reflects the drop in imports capacity of emerging countries due to the regional financial crises.

Table 4 gives the contribution of different importing regions to the market share growth, exports performance, and geographic structure effect shown in Table 3 . Thus, despite the 2.4\% decline in EU25's global market share, European countries obtained an important market share gain on the American market (5.8\%), a slight one on the Ukrainian market, maintained their shares in Mediterranean and Golf countries, and lost market shares in other countries and regions. The strong domestic demand of USA, China, and Mediterranean countries did not compensate for the important shrinkage of demand in Japan, Mercosur, and ASEAN countries, but prevented European exports from suffering a larger market share loss. Like other developed countries 
and Russia, the EU export performance was poor on each importing market, reducing thereby the growth of its exports to each of those countries of regions (Table 5). Table 6 shows that the negative geographical structure effect of the EU is composed of a positive effect for the American, Chinese, and Mediterranean markets, outweighed by the negative effects for Japan, Mecrosur, and ASEAN.

Tables 21 to 26 of Appendix B shows the decomposition of market share growth on the largest markets: USA, China, Japan, India, Brazil, and Russia. Since the partner dimension vanishes, no geographical structure is produced in this case. According to these results, the EU increased its market share on the American and Russian markets by $12 \%$, but lost shares on the other markets. By 2003 the EU lost $11 \%$ of its 1995 market share on the Chinese market, but this figure hides the exceptional performance of Germany, the best among large European countries and which increased its share by one fifth. Particularly disappointing is the reduction by half of EU's share on the Indian market, an importer with a large growth potential. This is the only case where European exports have a negative structure effect; on all other five importing markets the EU exports products with a rapidly growing global demand. However, since all other countries have a negative sectoral effect as well, this can be due to the large Indian demand for products with a slowly growing global demand.

Table 4: Decomposition of market share growth, by import market 1995-2003, (\%)

\begin{tabular}{l|cccccccc}
\hline \hline Market & EU25 & EU15 & Brazil & China & Japan & Russia & India & USA \\
\hline & \multicolumn{7}{|c}{ Volume } \\
\hline Japan & -2.7 & -2.8 & -1.9 & 6.4 & & -4.7 & -2.8 & -9.1 \\
Korea & -1.4 & -1.4 & -0.8 & 3.3 & -1.8 & -2.3 & -0.7 & -2.8 \\
Russia & -0.1 & 0.1 & 2.2 & -0.1 & 0.1 & & -0.9 & -0.2 \\
India & -0.5 & -0.5 & 0.1 & 0.8 & -0.2 & -1.2 & & -0.1 \\
Ukraine & 0.3 & 0.2 & 0.2 & 0.3 & 0.0 & 0.2 & 0.1 & -0.1 \\
USA & 1.6 & 0.9 & 6.6 & 14.5 & -15.8 & -6.2 & 6.1 & \\
Chinese world & -1.3 & -1.3 & 5.1 & 1.0 & 0.1 & -6.4 & 6.2 & -2.0 \\
Mediterranean & -0.2 & -0.3 & -0.3 & 1.0 & 0.3 & -4.2 & 1.6 & -0.5 \\
GCC & -0.4 & -0.5 & 1.3 & 1.7 & -0.2 & -0.7 & 5.0 & -1.5 \\
Mercosur & -1.9 & -2.0 & -4.2 & 0.5 & -0.5 & 0.4 & 0.3 & -2.3 \\
ASEAN & -4.6 & -4.8 & -1.9 & 4.5 & -9.9 & -4.8 & -0.7 & -2.4 \\
RoW & -3.9 & -4.6 & 7.1 & 29.3 & -7.4 & -19.7 & 11.0 & 18.0 \\
\hline & & & \multicolumn{7}{c}{ Value } & & & \\
\hline Japan & -2.0 & -2.3 & -2.8 & 6.4 & & -5.5 & -2.4 & -4.8 \\
Korea & -0.7 & -0.8 & -0.9 & 2.9 & -1.9 & -1.8 & -0.8 & -1.5 \\
Russia & -0.3 & 0.0 & 1.3 & 0.3 & 0.0 & & -2.3 & 0.0 \\
India & -0.3 & -0.3 & 0.1 & 0.6 & -0.2 & -0.4 & & 0.0 \\
Ukraine & 0.4 & 0.3 & 0.2 & 0.2 & 0.0 & 0.2 & 0.0 & 0.0 \\
USA & 5.8 & 5.6 & 8.1 & 18.4 & -10.6 & -9.9 & 6.7 & \\
Chinese world & 0.1 & 0.1 & 4.4 & 3.8 & 0.7 & -0.8 & 6.0 & -1.6 \\
Mediterranean & 0.1 & 0.1 & -0.7 & 0.7 & 0.1 & -3.9 & 1.3 & -0.9 \\
GCC & 0.1 & 0.1 & 0.8 & 1.1 & -0.2 & -0.1 & 4.2 & -0.2 \\
Mercosur & -1.7 & -1.9 & -4.6 & 0.4 & -0.6 & 0.3 & 0.3 & -1.6 \\
ASEAN & -3.0 & -3.4 & -2.0 & 4.4 & -10.9 & -3.8 & -0.8 & -1.8 \\
RoW & -1.0 & -1.7 & 3.1 & 26.8 & -8.0 & -16.0 & 7.2 & -1.0 \\
\hline \hline
\end{tabular}


Table 5: Decomposition of exports performance, by import market 1995-2003, (\%)

\begin{tabular}{l|cccccccc}
\hline \hline Market & EU25 & EU15 & Brazil & China & Japan & Russia & India & USA \\
\hline Japan & -1.3 & -1.4 & 1.4 & 17.2 & & -2.2 & 2.3 & -3.8 \\
Korea & -0.5 & -0.5 & 0.5 & 4.1 & -2.5 & -1.0 & 1.1 & -1.5 \\
Russia & -0.4 & -0.6 & 0.8 & 0.8 & -0.1 & & 1.2 & -0.2 \\
India & -0.3 & -0.3 & 0.2 & 0.5 & -0.2 & -0.4 & & -0.2 \\
Ukraine & 0.0 & -0.1 & 0.0 & 0.1 & 0.0 & -0.9 & 0.1 & 0.0 \\
USA & -5.7 & -6.1 & 10.7 & 26.1 & -11.9 & -2.7 & 10.6 & \\
Chinese world & -1.8 & -1.9 & 1.7 & 24.5 & -7.3 & -3.1 & 3.2 & -2.6 \\
Mediterranean & -1.7 & -1.8 & 0.6 & 0.9 & -0.3 & -1.4 & 1.3 & -0.5 \\
GCC & -1.0 & -1.0 & 0.7 & 1.5 & -0.8 & -0.1 & 5.5 & -0.6 \\
Mercosur & -0.6 & -0.7 & 5.0 & 0.9 & -0.3 & -0.2 & 0.6 & -1.2 \\
ASEAN & -1.1 & -1.2 & 0.7 & 6.3 & -5.3 & -1.0 & 4.7 & -2.0 \\
RoW & -6.9 & -7.5 & 19.8 & 31.9 & -12.2 & -14.3 & 29.5 & -30.2 \\
\hline & & & \multicolumn{7}{c}{ Value } & & & \\
\hline Japan & -0.7 & -0.8 & 1.6 & 17.5 & & -1.7 & 2.2 & -3.3 \\
Korea & -0.3 & -0.3 & 0.5 & 4.1 & -2.9 & -0.8 & 1.0 & -1.2 \\
Russia & -0.1 & -0.4 & 0.7 & 0.8 & -0.1 & & 1.2 & -0.2 \\
India & -0.2 & -0.2 & 0.2 & 0.5 & -0.2 & -0.3 & & -0.2 \\
Ukraine & 0.1 & -0.1 & 0.0 & 0.1 & 0.0 & -0.8 & 0.1 & 0.0 \\
USA & -3.3 & -3.8 & 10.3 & 26.5 & -12.2 & -2.3 & 9.6 & \\
Chinese world & -1.2 & -1.3 & 1.6 & 25.0 & -8.0 & -2.6 & 2.9 & -2.4 \\
Mediterranean & -1.1 & -1.2 & 0.6 & 0.9 & -0.3 & -1.2 & 1.1 & -0.4 \\
GCC & -0.6 & -0.6 & 0.6 & 1.5 & -0.8 & -0.1 & 4.9 & -0.6 \\
Mercosur & -0.5 & -0.5 & 5.2 & 0.9 & -0.4 & -0.2 & 0.5 & -1.0 \\
ASEAN & -0.7 & -0.9 & 0.8 & 6.4 & -6.2 & -0.8 & 4.3 & -1.7 \\
RoW & -4.2 & -4.9 & 19.1 & 32.2 & -12.4 & -12.4 & 26.9 & -27.6 \\
\hline \hline
\end{tabular}


Cheptea, Gaulier, Sondjo and Zignago (2006), Study Report

Table 6: Decomposition of the geographical structure effect, by import market 1995-2003, (\%)

\begin{tabular}{l|cccccccc}
\hline \hline Market & EU25 & EU15 & Brazil & China & Japan & Russia & India & USA \\
\hline Japan & -2.6 & -2.6 & -1.8 & -6.6 & & -2.7 & -1.7 & -4.0 \\
Korea & -0.6 & -0.6 & -0.3 & -0.8 & -1.2 & -0.5 & -0.4 & -1.3 \\
Russia & -0.5 & -0.4 & -0.1 & -0.1 & 0.0 & & -0.7 & -0.1 \\
India & 0.5 & 0.5 & 0.2 & 0.2 & 0.2 & 0.7 & & 0.3 \\
Ukraine & 0.3 & 0.2 & 0.0 & 0.0 & 0.0 & 0.7 & 0.1 & 0.0 \\
USA & 0.1 & 0.1 & -0.2 & 0.3 & 0.4 & 0.3 & 0.2 & \\
Chinese world & 0.3 & 0.3 & 1.0 & -13.0 & 0.3 & 5.8 & 0.3 & 0.5 \\
Mediterranean & 1.5 & 1.5 & 0.2 & 0.1 & 0.1 & 1.2 & 0.5 & 0.3 \\
GCC & 0.2 & 0.2 & 0.0 & 0.3 & 0.0 & -0.1 & 1.5 & -0.1 \\
Mercosur & -1.6 & -1.7 & -11.2 & -0.5 & -0.5 & -0.5 & -0.6 & -1.5 \\
ASEAN & -2.6 & -2.7 & -1.0 & -2.1 & -6.0 & -0.9 & -2.8 & -2.5 \\
RoW & 2.7 & 2.5 & 3.4 & 0.5 & 0.6 & 1.1 & 1.1 & 36.1 \\
\hline & & & \multicolumn{7}{c}{ Value } & & & \\
\hline Japan & -2.2 & -2.2 & -1.7 & -5.6 & & -2.4 & -1.5 & -3.5 \\
Korea & -0.3 & -0.3 & -0.1 & -0.3 & -0.3 & -0.0 & -0.7 & -0.8 \\
Russia & -0.8 & -0.6 & -0.2 & -0.1 & -0.0 & & -0.9 & -0.2 \\
India & 0.5 & 0.5 & 0.2 & 0.2 & 0.2 & 0.7 & & 0.2 \\
Ukraine & 0.4 & 0.3 & 0.1 & 0.1 & 0.0 & 1.7 & 0.1 & 0.0 \\
USA & 1.0 & 1.0 & 0.5 & 1.2 & 1.6 & 0.7 & 0.8 & \\
Chinese world & 1.7 & 1.8 & 1.8 & -10.4 & 3.3 & 8.9 & 1.2 & 1.6 \\
Mediterranean & 1.1 & 1.1 & 0.0 & 0.1 & 0.1 & 0.9 & 0.3 & 0.2 \\
GCC & 0.4 & 0.4 & 0.1 & 0.3 & 0.0 & 0.0 & 1.6 & 0.1 \\
Mercosur & -1.6 & -1.6 & -11.1 & -0.5 & -0.5 & -0.5 & -0.6 & -1.5 \\
ASEAN & -2.3 & -2.4 & -0.9 & -1.7 & -5.1 & -0.7 & -2.3 & -2.1 \\
RoW & 0.5 & 0.3 & 1.4 & 0.8 & 0.7 & 4.7 & 1.8 & 14.7 \\
\hline \hline
\end{tabular}

\subsection{Adaptation Effects}

Another useful aspect linked to the evolution of exports is the capacity of countries to adapt the geographical and sectoral structure of their exports to changing patters of global demand, i.e. their ability to export more on markets and sectors where the demand is growing at a quicker pace, and less on the others. These geographic and, respectively, sectoral adaptation effects can be computed in various ways. In our specific case, the adaptation is captured partially by the exports performance term, and partially by the two structure effects of the decomposition of exports growth given by equation (6) and Table 3 . Besides adaptation, exports performance includes as well price and non-price competitiveness of exports. Annual structure effects do not include any elements of countries' adaptation capacity, but their variation throughout the period due to year-specific weights used in their computation, leads to a part of the adaptation effect being attributed to the sectoral and geographical structure effects of the entire period. Under these conditions, one cannot express "total" geographic and sectoral adaptation effects as additional terms of the market share growth decomposition without altering all the other terms. Therefore, we choose to compute country-level adaptation effects as correlation 
coefficients between the variation of the share of different partners (products) in country's total exports and the corresponding partner (product) growth effect. We follow the exact steps described in detail in the last part of section 2.1. and display results in Table 7 .

Table 7: Adaptation effects during 1995-2003, (in \%)

\begin{tabular}{|c|c|c|c|c|}
\hline & \multicolumn{2}{|c|}{ Volume } & \multicolumn{2}{|r|}{ Value } \\
\hline & $\begin{array}{l}\text { geographic } \\
\text { adaptation } \\
\text { effect }\end{array}$ & $\begin{array}{l}\text { sectoral adap- } \\
\text { tation effect }\end{array}$ & $\begin{array}{l}\text { geographic } \\
\text { adaptation } \\
\text { effect }\end{array}$ & $\begin{array}{l}\text { sectoral adap- } \\
\text { tation effect }\end{array}$ \\
\hline EU25 & -4.8 & -4.0 & -5.6 & -5.7 \\
\hline EU15 & -2.4 & -3.5 & -3.4 & -3.8 \\
\hline Austria & 2.5 & -12.6 & 1.7 & -10.3 \\
\hline Belgium \& Lux & 20.3 & -2.7 & 10.4 & -4.1 \\
\hline Cyprus & -16.4 & -0.7 & -23.3 & 16.4 \\
\hline Czech Rep. & -16.7 & 6.1 & -17.8 & -6.0 \\
\hline Denmark & -9.7 & -12.4 & -8.1 & -16.8 \\
\hline Estonia & -105.8 & -35.1 & -97.1 & -32.9 \\
\hline Finland & 0.1 & 3.3 & -3.8 & -0.1 \\
\hline France & -5.9 & -10.3 & -8.3 & -11.0 \\
\hline Germany & -6.0 & 3.6 & -4.0 & 4.2 \\
\hline Greece & -16.2 & -19.3 & -23.3 & -18.4 \\
\hline Hungary & -17.5 & -3.4 & -20.2 & -12.2 \\
\hline Ireland & -26.1 & -10.5 & -26.2 & 12.4 \\
\hline Italy & -3.0 & -6.0 & -5.4 & -7.5 \\
\hline Latvia & -60.9 & -72.1 & -54.3 & -73.7 \\
\hline Lithuania & -48.5 & -11.6 & -57.1 & -23.0 \\
\hline Malta & -121.7 & -8.6 & -125.2 & -59.9 \\
\hline Netherlands & -2.1 & -5.6 & -3.1 & -9.2 \\
\hline Poland & -1.4 & -1.6 & -5.3 & -19.3 \\
\hline Portugal & -1.5 & 1.6 & -6.4 & -8.7 \\
\hline Slovakia & -39.9 & -28.9 & -43.2 & -32.1 \\
\hline Slovenia & 9.4 & -22.5 & 6.9 & -32.5 \\
\hline Spain & 14.6 & -5.3 & 12.6 & -14.8 \\
\hline Sweden & 7.2 & -27.4 & 0.9 & -34.8 \\
\hline$U K$ & 2.1 & 2.1 & 0.6 & 4.4 \\
\hline USA & 14.1 & -4.1 & 16.1 & -0.9 \\
\hline Japan & -4.5 & 1.2 & -1.1 & 3.0 \\
\hline China & 21.2 & 17.2 & 18.6 & 18.5 \\
\hline Brazil & 15.2 & 4.1 & 9.4 & -7.6 \\
\hline India & -2.6 & 9.9 & -4.3 & 4.6 \\
\hline
\end{tabular}

Note: Adaptation effects are the correlation coefficients between the global trade growth by partner and product, and the variation of geographic, respectively sectoral, trade shares. Some coefficients are inferior to $-100 \%$ because reported coefficients are deviations from the world average of correlations. 
Cheptea, Gaulier, Sondjo and Zignago (2006), Study Report

Computed in this way, adaptation effects reflect the distance between the change in geographical (sectoral) specialisation of different countries and the global geographical (sectoral) exports dynamics. From all countries in the sample, China displays one of the best adaptation effects, both geographical and sectoral. Contrary to most countries, its adaptation effects are very good for trade expressed in volume terms, but poor (negative) for the evolution of prices (computed as the difference between the adaptation in value terms and in volume terms). Thus, while most countries succeed only to export more products with increasing world prices and less with falling prices, China adapts the structure of its exports only to changes in physical demand.

EU has small negative adaptation effects, but certain members succeed in adapting their exports to shifts in global demand patters. Ireland, Germany, and UK are successful in adapting the sectoral breakdown of their exports; Belgium and Spain in switching to more rapidly importing partners.

\section{Sector Level Performance of Exports}

The evolution of European exports varied significantly across products. Market shares held by the EU and other large countries and groups of countries in different sectors, and their 1995-2003 variation are shown in Table 8. European countries acquired important market shares in capital-intensive sectors in which they hold large comparative advantages (chemicals, machinery, and motor vehicles), but also in some sectors accounting for a small part of European exports (agriculture, forestry, fishing) or where they have recently lost comparative advantage to emerging South competitors (office machinery and computers, radio, TV and communication equipment). The large positive sectoral structure effect in the decomposition of market share growth of the EU (shown in Table 3) is due to the dynamic global demand and to the specialisation of European exports in higher price (up-market) products within these very sectors (see Table 28 of Appendix B.

Corresponding revealed comparative advantages, computed as the contribution of each sector to the trade balance (CTB) are displayed in Table 9 . Details of the computation technique employed are discussed in section 2.2. Large positive values of the CTB denote sectors where countries detain strong comparative advantages, and which account for a large share of their exports. If a country has no comparative advantage, the analysis is done in terms of smaller and larger disadvantages, reflected by similar size negative CTB.

Differently from European countries, Japan and US lost market share in all sectors, including the ones in which they have a traditional comparative advantage. The only exceptions are other transport equipment for USA and fishing for Japan. Thus, even at sector level, EU exports benefited from a better positioning.

Figures reveal as well the strong emergence of southern countries as global exporters, in particular China. By 2003 Chinese exports reached $41 \%$ of the world market on furniture, $38 \%$ on leather, and $32 \%$ on wearing apparel. They continue to expand rapidly in many other sectors, including office machinery and computers (a fivefold increase of the 1995 market share), radio, TV, and communication equipment (14.3 p.p.), and electrical machinery (9.4 p.p.). In 2003 China accounted for $16.6 \%$ of world's exports of consumption goods, i.e. the sum of the shares of American and Japanese exports (see Table 27 and Figure 6 of Appendix B.

EU firms withdrew from low range segments within sectors while maintaining a significant presence in a vast majority of industries. Thus, the EU reinforced or acquired the leadership in up-markets in many industries ranging from leather or clothing (thanks to Italy) to machinery or automobile. Yet, it did not manage to build a sufficiently strong advantage in up-market technology to balance its large and deepening disadvantage in the lower range of the high tech sector (especially for computer devices, where China is dominant). Therefore the technological sector remains among the comparative disadvantage of the EU. Country level comparative advantages of EU25 are shown in Table 29 of Appendix B. 
European Positioning in the International Division of Labour

Table 8: Market shares by sector in 2003 and change during 1995-2003, (in \% and p.p.)

\begin{tabular}{|c|c|c|c|c|c|c|c|c|c|c|c|c|}
\hline & \multicolumn{2}{|c|}{$\begin{array}{l}\text { Agriculture, } \\
\text { hunting }\end{array}$} & \multicolumn{2}{|c|}{$\begin{array}{l}\text { Forestry, } \\
\text { logging }\end{array}$} & \multicolumn{2}{|c|}{$\begin{array}{l}\text { Fishing, fish } \\
\text { farming }\end{array}$} & \multicolumn{2}{|c|}{$\begin{array}{l}\text { Food products \& } \\
\text { beverages }\end{array}$} & \multicolumn{2}{|c|}{ Tobacco products } & \multicolumn{2}{|c|}{ Textiles } \\
\hline & 2003 & $\Delta$ & 2003 & $\Delta$ & 2003 & $\Delta$ & 2003 & $\Delta$ & 2003 & $\Delta$ & 2003 & $\Delta$ \\
\hline EU25 & 8.3 & 0.9 & 10.1 & 1.9 & 5.1 & 1.9 & 19.6 & -3.2 & 22.2 & 3.8 & 13.2 & -1.3 \\
\hline France & 1.8 & 0.4 & 1.8 & 0.6 & 0.7 & 0.2 & 3.9 & -0.7 & 1.4 & 0.8 & 1.6 & -0.2 \\
\hline Germany & 1.0 & -0.1 & 2.7 & 1.2 & 0.1 & -0.2 & 1.7 & -1.0 & 5.0 & 1.1 & 2.3 & -1.0 \\
\hline Italy & 0.6 & 0.0 & 0.9 & 0.1 & 0.3 & 0.0 & 2.6 & 0.5 & 0.1 & 0.1 & 4.4 & 0.0 \\
\hline Poland & 0.2 & 0.1 & 0.0 & 0.0 & 0.0 & 0.0 & 0.5 & 0.1 & 0.6 & 0.5 & 0.1 & 0.0 \\
\hline Spain & 0.6 & 0.3 & 0.9 & 0.2 & 1.3 & 0.7 & 1.5 & 0.2 & 0.2 & -0.1 & 0.8 & 0.2 \\
\hline UK & 0.4 & 0.1 & 0.3 & 0.0 & 1.3 & 0.7 & 2.3 & -0.5 & 8.4 & -1.3 & 1.2 & -0.3 \\
\hline Japan & 0.2 & 0.0 & 0.4 & 0.0 & 2.4 & 0.3 & 0.8 & -0.1 & 3.1 & -0.2 & 3.0 & -2.6 \\
\hline Korea & 0.2 & 0.0 & 0.6 & -0.1 & 3.8 & -3.3 & 0.9 & -0.4 & 3.3 & 3.2 & 5.7 & -4.2 \\
\hline Russia & 1.1 & 0.5 & 22.9 & 12.0 & 1.0 & -2.8 & 1.2 & -0.3 & 2.3 & 2.3 & 0.4 & 0.2 \\
\hline India & 1.8 & 0.2 & 3.1 & 1.5 & 0.8 & 0.1 & 2.1 & 0.0 & 0.8 & 0.6 & 4.9 & 0.7 \\
\hline Ukraine & 0.5 & 0.3 & 0.8 & 0.8 & 0.0 & 0.0 & 0.7 & 0.6 & 0.6 & 0.6 & 0.1 & 0.1 \\
\hline USA & 25.6 & -4.1 & 19.1 & -5.7 & 8.1 & -1.1 & 13.2 & -1.5 & 28.8 & -13.1 & 6.5 & -0.4 \\
\hline Chinese world & 6.5 & 1.7 & 3.2 & 0.5 & 12.5 & -2.9 & 6.4 & 0.0 & 6.3 & -4.0 & 34.6 & 3.7 \\
\hline China & 6.2 & 2.0 & 3.0 & 0.8 & 9.1 & -0.5 & 5.5 & 1.2 & 3.5 & -4.9 & 24.9 & 6.7 \\
\hline Hong Kong & 0.1 & 0.0 & 0.1 & -0.1 & 0.2 & -1.0 & 0.2 & -0.1 & 2.7 & 0.8 & 5.5 & 0.5 \\
\hline Mediterranean & 2.8 & -0.1 & 0.9 & 0.2 & 3.5 & 1.2 & 2.0 & -0.2 & 1.2 & 0.1 & 6.7 & 2.2 \\
\hline GCC & 0.3 & -0.1 & 0.0 & 0.0 & 0.8 & 0.5 & 0.5 & 0.1 & 4.4 & 1.9 & 0.4 & 0.1 \\
\hline Mercosur & 12.0 & 3.9 & 1.2 & -0.6 & 0.9 & 0.3 & 10.2 & 1.0 & 1.7 & -2.4 & 1.0 & -0.5 \\
\hline Brazil & 6.6 & 2.7 & 0.6 & -0.6 & 0.7 & 0.4 & 5.2 & 0.6 & 1.1 & -2.9 & 0.7 & -0.2 \\
\hline ASEAN & 4.5 & -1.3 & 9.1 & -9.4 & 9.3 & -1.9 & 12.5 & -0.2 & 7.9 & -2.8 & 6.3 & -0.7 \\
\hline RoW & 36.1 & -1.9 & 28.5 & -1.1 & 51.7 & 7.8 & 29.9 & 4.3 & 17.5 & 10.2 & 17.4 & 2.8 \\
\hline All & 100 & 0 & 100 & 0 & 100 & 0 & 100 & 0 & 100 & 0 & 100 & 0 \\
\hline
\end{tabular}

\begin{tabular}{|c|c|c|c|c|c|c|c|c|c|c|c|c|}
\hline & \multicolumn{2}{|c|}{$\begin{array}{l}\text { Wearing } \\
\text { apparel }\end{array}$} & \multicolumn{2}{|c|}{ Leather } & \multicolumn{2}{|l|}{ Wood } & \multicolumn{2}{|c|}{$\begin{array}{l}\text { Pulp, paper \& pa- } \\
\text { per products }\end{array}$} & \multicolumn{2}{|c|}{$\begin{array}{l}\text { Publishing, print- } \\
\text { ing \& reproduction } \\
\text { of recorded media }\end{array}$} & \multicolumn{2}{|c|}{$\begin{array}{l}\text { Chemicals } \\
\& \text { chemica } \\
\text { products }\end{array}$} \\
\hline & 2003 & $\Delta$ & 2003 & $\Delta$ & 2003 & $\Delta$ & 2003 & $\Delta$ & 2003 & $\Delta$ & 2003 & $\Delta$ \\
\hline EU25 & 7.7 & -2.1 & 17.5 & -4.0 & 18.7 & 8.0 & 23.6 & 3.4 & 30.1 & -5.5 & 31.4 & 3.6 \\
\hline France & 1.0 & -0.5 & 2.3 & -0.2 & 1.3 & 0.5 & 2.0 & 0.2 & 4.0 & -0.7 & 4.4 & 0.0 \\
\hline Germany & 1.1 & -0.7 & 1.3 & -0.6 & 3.6 & 2.1 & 5.2 & 0.9 & 7.5 & -1.6 & 7.5 & -1.2 \\
\hline Italy & 3.5 & -0.4 & 10.6 & -0.9 & 1.2 & 0.2 & 1.6 & 0.4 & 2.5 & 0.3 & 2.4 & 0.1 \\
\hline Poland & 0.1 & 0.0 & 0.1 & 0.0 & 0.5 & 0.4 & 0.6 & 0.5 & 0.3 & 0.3 & 0.2 & 0.0 \\
\hline Spain & 0.5 & 0.2 & 1.2 & -0.6 & 0.7 & 0.3 & 0.8 & 0.2 & 2.3 & 0.3 & 1.3 & 0.5 \\
\hline UK & 0.5 & -0.3 & 0.5 & -0.8 & 0.2 & 0.0 & 1.5 & -0.1 & 8.9 & -0.8 & 4.2 & -0.1 \\
\hline Japan & 0.2 & -0.2 & 0.3 & -0.4 & 0.2 & -0.1 & 3.5 & -0.1 & 2.0 & -2.9 & 9.0 & -3.6 \\
\hline Korea & 1.6 & -2.0 & 2.6 & -4.5 & 0.2 & -0.2 & 2.5 & 0.7 & 1.1 & 0.1 & 3.9 & 0.3 \\
\hline Russia & 0.3 & 0.1 & 0.4 & 0.1 & 4.3 & 2.3 & 2.5 & 0.7 & 0.9 & 0.8 & 1.6 & 0.2 \\
\hline India & 4.3 & -0.1 & 3.2 & 0.2 & 0.3 & 0.1 & 0.3 & 0.2 & 0.7 & 0.3 & 1.6 & 0.9 \\
\hline Ukraine & 0.3 & 0.1 & 0.3 & 0.1 & 0.6 & 0.5 & 0.3 & 0.3 & 0.1 & 0.1 & 0.3 & -0.1 \\
\hline USA & 2.1 & -2.4 & 2.9 & -0.3 & 8.9 & -3.1 & 19.2 & -4.0 & 25.4 & -5.0 & 19.6 & -1.6 \\
\hline Chinese world & 39.2 & 2.8 & 43.2 & 8.1 & 13.2 & 6.2 & 5.3 & 2.2 & 16.7 & 9.3 & 7.6 & 0.9 \\
\hline China & 32.3 & 6.3 & 38.0 & 9.5 & 12.3 & 6.6 & 3.1 & 1.9 & 11.0 & 8.3 & 4.1 & 1.0 \\
\hline Hong Kong & 5.9 & -2.3 & 3.3 & 0.9 & 0.5 & 0.3 & 1.1 & 0.4 & 4.9 & 1.4 & 0.5 & 0.1 \\
\hline Mediterranean & 9.1 & 0.2 & 1.8 & 0.5 & 0.5 & 0.2 & 0.6 & 0.3 & 0.4 & 0.1 & 0.9 & -0.2 \\
\hline GCC & 0.6 & -0.1 & 0.2 & 0.0 & 0.0 & 0.0 & 0.3 & 0.0 & 0.2 & 0.1 & 1.7 & 0.0 \\
\hline Mercosur & 0.2 & -0.2 & 6.4 & -0.7 & 4.9 & 1.6 & 4.1 & -0.1 & 0.6 & -0.1 & 1.4 & -0.1 \\
\hline Brazil & 0.1 & -0.1 & 4.6 & 0.1 & 4.3 & 1.4 & 3.6 & -0.2 & 0.3 & 0.1 & 0.9 & -0.1 \\
\hline ASEAN & 10.8 & -0.9 & 11.0 & -1.0 & 10.5 & -15.3 & 6.6 & 3.2 & 5.1 & -1.4 & 5.8 & 1.4 \\
\hline RoW & 23.4 & 4.6 & 10.2 & 1.9 & 37.8 & -0.2 & 31.3 & -6.8 & 16.7 & 4.2 & 15.3 & -1.6 \\
\hline All & 100 & 0 & 100 & 0 & 100 & 0 & 100 & 0 & 100 & 0 & 100 & 0 \\
\hline
\end{tabular}


Cheptea, Gaulier, Sondjo and Zignago (2006), Study Report

\begin{tabular}{|c|c|c|c|c|c|c|c|c|c|c|c|c|}
\hline & \multicolumn{2}{|c|}{$\begin{array}{l}\text { Rubber \& } \\
\text { plastic }\end{array}$} & \multicolumn{2}{|c|}{$\begin{array}{l}\text { Non-metallic } \\
\text { mineral products }\end{array}$} & \multicolumn{2}{|c|}{ Basic metals } & \multicolumn{2}{|c|}{ Metal products } & \multicolumn{2}{|c|}{ Machinery } & \multicolumn{2}{|c|}{$\begin{array}{l}\text { Office ma- } \\
\text { chinery } \quad \& \\
\text { computers }\end{array}$} \\
\hline & 2003 & $\Delta$ & 2003 & $\Delta$ & 2003 & $\Delta$ & 2003 & $\Delta$ & 2003 & $\Delta$ & 2003 & $\Delta$ \\
\hline EU25 & 19.6 & 0.0 & 32.3 & -5.4 & 13.1 & -3.1 & 24.0 & -3.4 & 34.2 & -1.1 & 8.0 & -1.6 \\
\hline France & 2.2 & -0.2 & 3.0 & -1.9 & 1.2 & -0.7 & 2.3 & -1.1 & 3.0 & -0.3 & 0.4 & -0.5 \\
\hline Germany & 6.3 & 0.1 & 6.7 & -0.8 & 3.8 & -0.8 & 7.6 & -0.8 & 12.9 & -1.0 & 1.6 & -0.2 \\
\hline Italy & 2.7 & -0.1 & 8.5 & -1.8 & 1.5 & -0.2 & 3.9 & -0.8 & 7.0 & 0.0 & 0.4 & -0.5 \\
\hline Poland & 0.4 & 0.2 & 0.7 & 0.4 & 0.3 & -0.1 & 0.5 & 0.3 & 0.2 & 0.1 & 0.0 & 0.0 \\
\hline Spain & 0.9 & 0.0 & 4.0 & 0.3 & 0.5 & -0.3 & 1.2 & 0.2 & 0.8 & 0.1 & 0.3 & 0.1 \\
\hline UK & 2.0 & -0.5 & 2.1 & -1.6 & 2.1 & -0.4 & 2.2 & -1.2 & 3.3 & -0.9 & 1.6 & -1.5 \\
\hline Japan & 11.3 & -2.3 & 9.4 & -4.4 & 7.7 & -3.8 & 7.9 & -4.4 & 16.1 & -7.1 & 14.8 & -8.8 \\
\hline Korea & 4.3 & -0.3 & 2.0 & 0.3 & 3.5 & -0.9 & 3.4 & -1.6 & 3.9 & 1.5 & 7.2 & 3.2 \\
\hline Russia & 0.6 & 0.5 & 0.9 & 0.7 & 8.3 & 0.8 & 0.9 & 0.7 & 0.4 & 0.3 & 0.0 & 0.0 \\
\hline India & 1.0 & 0.2 & 1.6 & 0.5 & 1.5 & 0.9 & 2.0 & 0.8 & 0.5 & 0.3 & 0.1 & 0.0 \\
\hline Ukraine & 0.1 & 0.1 & 0.3 & 0.3 & 1.9 & 1.0 & 0.2 & 0.2 & 0.2 & 0.2 & 0.0 & 0.0 \\
\hline USA & 16.8 & -0.3 & 10.8 & -1.4 & 9.2 & -1.9 & 14.8 & -1.4 & 15.5 & -2.3 & 10.9 & -11.0 \\
\hline Chinese world & 18.0 & 4.7 & 17.7 & 6.7 & 8.9 & 3.0 & 24.4 & 7.9 & 11.7 & 5.6 & 35.5 & 21.5 \\
\hline China & 13.5 & 6.2 & 15.5 & 7.2 & 4.0 & 0.4 & 17.8 & 8.7 & 8.6 & 5.8 & 24.3 & 19.6 \\
\hline Hong Kong & 1.3 & 0.1 & 0.6 & 0.2 & 2.3 & 2.0 & 1.1 & -0.3 & 0.7 & 0.1 & 3.7 & 2.2 \\
\hline Mediterranean & 1.5 & 0.6 & 3.5 & 1.6 & 1.8 & 0.3 & 1.6 & 0.8 & 0.8 & 0.5 & 0.0 & 0.0 \\
\hline GCC & 0.3 & -0.1 & 1.1 & 0.6 & 1.4 & 0.5 & 0.4 & -0.2 & 0.3 & 0.2 & 0.2 & 0.1 \\
\hline Mercosur & 1.4 & -0.1 & 2.3 & 0.0 & 3.5 & -0.6 & 1.0 & -0.3 & 1.2 & 0.1 & 0.1 & -0.1 \\
\hline Brazil & 1.1 & -0.1 & 2.1 & 0.2 & 3.0 & -0.6 & 0.9 & -0.2 & 1.1 & 0.1 & 0.1 & -0.1 \\
\hline ASEAN & 11.6 & -4.4 & 6.3 & 1.0 & 3.3 & 0.0 & 3.7 & -0.6 & 3.2 & 0.3 & 18.4 & -3.7 \\
\hline RoW & 13.4 & 1.3 & 11.7 & -0.6 & 36.0 & 3.6 & 15.7 & 1.7 & 12.0 & 1.4 & 4.6 & 0.2 \\
\hline All & 100 & 0 & 100 & 0 & 100 & 0 & 100 & 0 & 100 & 0 & 100 & 0 \\
\hline
\end{tabular}

\begin{tabular}{|c|c|c|c|c|c|c|c|c|c|c|c|c|}
\hline & \multicolumn{2}{|c|}{$\begin{array}{l}\text { Electrical } \\
\text { machinery }\end{array}$} & \multicolumn{2}{|c|}{$\begin{array}{l}\text { Radio, TV \& } \\
\text { communication } \\
\text { equipment }\end{array}$} & \multicolumn{2}{|c|}{$\begin{array}{l}\text { Medical, preci- } \\
\text { sion \& optical } \\
\text { instruments }\end{array}$} & \multicolumn{2}{|c|}{$\begin{array}{l}\text { Motor vehicles, } \\
\text { trailers \& semi- } \\
\text { trailers }\end{array}$} & \multicolumn{2}{|c|}{$\begin{array}{l}\text { Other trans- } \\
\text { port equip- } \\
\text { ment }\end{array}$} & \multicolumn{2}{|c|}{$\begin{array}{l}\text { Furniture; } \\
\text { manufactur- } \\
\text { ing n.e.c. }\end{array}$} \\
\hline & 2003 & $\Delta$ & 2003 & $\Delta$ & 2003 & $\Delta$ & 2003 & $\Delta$ & 2003 & $\Delta$ & 2003 & $\Delta$ \\
\hline EU25 & 19.5 & -1.6 & 13.1 & 1.7 & 23.8 & -0.1 & 25.4 & 2.2 & 25.1 & -1.1 & 16.5 & -4.3 \\
\hline France & 3.0 & -0.6 & 1.8 & 0.1 & 2.3 & -0.4 & 2.3 & 0.1 & 8.5 & -3.8 & 1.6 & -0.7 \\
\hline Germany & 7.4 & -0.5 & 3.3 & 0.2 & 9.4 & -0.9 & 13.7 & 1.8 & 5.4 & 1.9 & 3.6 & -1.0 \\
\hline Italy & 1.9 & -0.1 & 0.5 & -0.1 & 2.1 & 0.0 & 1.2 & -0.6 & 2.6 & 1.2 & 4.7 & -1.6 \\
\hline Poland & 0.2 & 0.1 & 0.1 & 0.1 & 0.0 & 0.0 & 0.1 & 0.1 & 0.6 & 0.5 & 0.6 & 0.3 \\
\hline Spain & 0.6 & 0.1 & 0.2 & -0.2 & 0.3 & 0.1 & 0.9 & 0.0 & 0.6 & -0.4 & 0.8 & 0.1 \\
\hline UK & 2.2 & -0.8 & 1.5 & -0.4 & 4.0 & -0.3 & 2.7 & 0.3 & 4.3 & 0.3 & 1.2 & -0.6 \\
\hline Japan & 13.6 & -8.9 & 14.2 & -11.1 & 17.6 & -8.8 & 25.3 & -7.1 & 11.7 & -7.7 & 5.4 & -4.6 \\
\hline Korea & 3.0 & -1.4 & 12.2 & 0.8 & 1.7 & 0.1 & 5.3 & 1.8 & 6.5 & 0.1 & 1.6 & -1.8 \\
\hline Russia & 0.5 & 0.4 & 0.0 & 0.0 & 0.4 & 0.3 & 0.3 & 0.2 & 1.6 & 1.3 & 0.3 & 0.2 \\
\hline India & 0.6 & 0.4 & 0.1 & 0.1 & 0.3 & 0.2 & 0.3 & 0.0 & 0.3 & -0.2 & 0.6 & 0.3 \\
\hline Ukraine & 0.1 & 0.1 & 0.0 & 0.0 & 0.0 & 0.0 & 0.0 & 0.0 & 0.3 & 0.3 & 0.1 & 0.1 \\
\hline USA & 13.2 & -2.6 & 8.5 & -5.7 & 23.7 & -4.1 & 13.0 & -1.6 & 32.6 & 1.9 & 6.5 & -2.9 \\
\hline Chinese world & 23.6 & 9.5 & 28.2 & 16.4 & 16.1 & 8.4 & 1.4 & 0.8 & 5.8 & 1.2 & 46.7 & 11.7 \\
\hline China & 17.8 & 9.4 & 20.3 & 14.3 & 8.7 & 4.5 & 1.0 & 0.6 & 4.1 & 2.3 & 41.2 & 14.7 \\
\hline Hong Kong & 2.5 & 0.7 & 3.1 & 1.1 & 1.5 & 0.3 & 0.0 & 0.0 & 0.3 & 0.1 & 3.0 & 0.3 \\
\hline Mediterranean & 1.6 & 0.8 & 0.3 & 0.1 & 0.1 & 0.1 & 1.4 & 1.1 & 0.4 & 0.3 & 0.8 & 0.5 \\
\hline GCC & 0.2 & 0.0 & 0.5 & 0.5 & 0.1 & -0.1 & 0.2 & -0.1 & 0.6 & 0.4 & 0.1 & 0.0 \\
\hline Mercosur & 0.7 & 0.0 & 0.8 & 0.6 & 0.2 & 0.0 & 2.1 & 0.0 & 1.5 & 0.9 & 1.1 & 0.2 \\
\hline Brazil & 0.6 & 0.0 & 0.8 & 0.6 & 0.2 & 0.0 & 1.7 & 0.3 & 1.4 & 0.9 & 0.8 & 0.1 \\
\hline ASEAN & 6.9 & 0.2 & 15.5 & -4.2 & 4.8 & 0.8 & 1.3 & 0.8 & 1.7 & -1.2 & 7.8 & -0.7 \\
\hline RoW & 16.5 & 3.3 & 6.5 & 0.9 & 11.1 & 3.0 & 24.0 & 1.8 & 12.0 & 3.7 & 12.6 & 1.4 \\
\hline All & 100 & 0 & 100 & 0 & 100 & 0 & 100 & 0 & 100 & 0 & 100 & 0 \\
\hline
\end{tabular}


Note, that in some technological sectors the US has relatively large deficits. Nevertheless, the country has a comparative advantages in some of these sectors, since one needs to take into account the country's large trade deficit, which we attribute to macroeconomic factors (lack of domestic saving, etc.) rather than to trade related factors. The CTB indicator is designed to account for such structural sectoral surplus or deficits that reveal comparative advantage, respectively disadvantage.

Japan's specialisation remains quite intense, with a relatively large concentration of exports in a small number of sectors (mainly machinery, motor vehicles, radio, TV, and communication equipment). By contrast, the specialisation along technological levels or quality ranges is less and less marked. This is compatible with about half the Japanese exports being up-market, since imports also consist of up-market products.

\section{Exports Performance on Up-market, Mid-market, and Low-market Products}

\subsection{The Classification of Products according to their Quality}

To test the hypothesis that regional integration is followed by a specialization along a quality range, one needs first to measure the quality of traded goods. We classify international trade flows into three large similar-size quality ranges according to the principle that high-quality products are also the more expensive ones, i.e. have the highest unit-values. For each 6-digit HS product and year we compute the average world unit value, noted by $\overline{U V}$. Then, each trade flow is classified as follows:

- Flows with unit values differing from the world average by less than $25 \%$, i.e. comprised in the interval $[0.75 \overline{U V} ; 1.25 \overline{U V}]$ along with the last decile of $\left[\min \left(U V_{i j k}\right) ; 0.75 \overline{U V}\right]$ and the first decile of $[1.25$ $\left.\overline{U V} ; \max \left(U V_{i j k}\right)\right]$ are attributed to the medium quality range or middle-market;

- The first nine deciles of $\left[\min \left(U V_{i j k}\right) ; 0.75 \overline{U V}\right]$ are considered low range or low-market;

- The last nine deciles of $\left[1.25 \overline{U V} ; \max \left(U V_{i j k}\right)\right]$ are considered high range or up-market.

This method permits to take into account the high variability of unit values, and to have a significant share of trade in the medium range. Moreover, since exports and imports are analysed separately, flows for the same product with a given trade partner can exist in different price/quality ranges. Besides intrinsic quality, this taxonomy based on differences in prices (unit values) reflects additional aspects, such as trade-mark effects or the capacity of countries to sell their products at high prices.

One shortcoming of this approach is that trade flows for which quantity is not reported in the data cannot be classified. But since we work with harmonised data (we use the export report when the import report is not available, and reciprocally), the later represent a small proportion (only 9\%) of world trade in value terms.

\subsection{Exports Performance by Quality Range}

The shares of different countries in global trade in 2003 and the evolution of these market shares by the quality of exported goods is displayed in Table 10 . The last two columns of table 10 show average market shares and their evolution for all trade flows which can be classified according the approach described above. This explains the difference in results with respect to Table 1 . A first conclusion that can be drawn from these figures is that all industrialised countries enjoy a larger share in up-market products, while developing countries tend to dominate low-market segments. Evolutions since 1995 led to a reinforcement of EU's specialisation in highquality products in the detriment of low- and middle-quality goods. US lost market share in all segments, except 
Cheptea, Gaulier, Sondjo and Zignago (2006), Study Report

Table 9: CTB by industry in 1995 and 2003

\begin{tabular}{|c|c|c|c|c|c|c|c|}
\hline \multicolumn{8}{|c|}{ CTB by industry in 1995} \\
\hline & EU25 & USA & Japan & Korea & India & Russia & China \\
\hline Agriculture, hunting & -16.4 & 17.6 & -16.9 & -14.3 & 13.1 & -9.9 & -5.0 \\
\hline Forestry, logging & -0.8 & 1.0 & -4.9 & -3.0 & -0.7 & 13.2 & -0.5 \\
\hline Fishing, fish farming & -0.8 & -0.2 & -3.7 & 0.6 & 0.7 & 2.3 & 1.2 \\
\hline Food \& beverages & 4.2 & 5.5 & -48.2 & -10.7 & 38.9 & -68.8 & -2.9 \\
\hline Tobacco & -0.1 & 2.0 & -1.8 & -1.0 & 0.5 & -2.0 & 0.5 \\
\hline Textiles & -6.6 & -5.0 & -13.9 & 31.5 & 66.8 & -10.8 & 16.6 \\
\hline Wearing apparel & -16.1 & -18.2 & -21.6 & 8.2 & 57.7 & -15.4 & 58.6 \\
\hline Leather & -2.8 & -7.9 & -6.8 & 9.2 & 16.8 & -13.6 & 25.8 \\
\hline Wood & -3.5 & -3.7 & -15.1 & -6.7 & 0.8 & 8.8 & -0.7 \\
\hline Pulp \& paper & 2.6 & 3.3 & -3.0 & -4.5 & -7.9 & 10.9 & -7.9 \\
\hline Publishing \& printing & 1.3 & 4.5 & -2.3 & -1.4 & -1.2 & -2.6 & 0.4 \\
\hline Coke, refined petroleum & -0.1 & 0.3 & -0.5 & -0.3 & -0.1 & 4.9 & -0.1 \\
\hline Chemicals & 28.2 & 25.5 & -11.0 & -24.3 & -59.5 & 26.4 & -45.8 \\
\hline Rubber \& plastic & -0.4 & 1.3 & 2.3 & 6.8 & 2.2 & -12.2 & 5.2 \\
\hline Non-metallic mineral prod. & 5.1 & -1.5 & -0.2 & -4.3 & 2.8 & -5.4 & 3.6 \\
\hline Basic metals & -4.5 & -3.2 & -5.5 & -26.7 & -39.2 & 222.7 & -25.8 \\
\hline Metal products & 2.6 & -0.3 & 0.6 & 6.2 & 8 & -10.0 & 6.3 \\
\hline Machinery & 36.5 & 13.7 & 40.2 & -44.5 & -65.0 & -51.2 & -50.1 \\
\hline Office mach. \& computers & -36.1 & -7.0 & 13.0 & 12.8 & -7.8 & -15.7 & 12.2 \\
\hline Electrical machinery & 0.1 & -3.6 & 14.2 & 5.9 & -16.3 & -8.9 & 5.6 \\
\hline Radio, TV \& comm. equip. & -11.0 & -8.9 & 37.9 & 60.2 & -18.1 & -27.5 & -10.1 \\
\hline Medical, precision \& opt. inst. & -6.7 & 13.2 & 5.3 & -21.8 & -16.5 & -17.2 & -2.9 \\
\hline Motor vehicles & 26.8 & -36.2 & 56.5 & 15.6 & -4.9 & -17.0 & -9.4 \\
\hline Other transport equipment & 2.5 & 22.5 & 3.6 & 4.1 & -18.7 & 1.1 & -11.3 \\
\hline Furniture; manuf. n.e.c. & -2.2 & -14.5 & -18.2 & 2.8 & 95.6 & -7.4 & 37.2 \\
\hline Degree of specialisation & 14.1 & 2.7 & 20.7 & $\mathbf{1 9 . 5}$ & 35.7 & 49.3 & 21.6 \\
\hline \multicolumn{8}{|c|}{ CTB by industry in 2003} \\
\hline & EU25 & $\overline{\text { USA }}$ & Japan & Korea & India & Russia & China \\
\hline Agriculture, hunting & -12.5 & 15.3 & -19.3 & -12.3 & 10.2 & -11.0 & -5.9 \\
\hline Forestry, logging & -0.7 & 0.8 & -2.7 & -2.0 & -2.6 & 15.4 & -2.5 \\
\hline Fishing, fish farming & -1.1 & -0.3 & -3.4 & -1.0 & 0.5 & 0.3 & 0.3 \\
\hline Food \& beverages & 3.0 & 2.5 & -47.4 & -18.7 & 12.7 & -47.1 & 0.6 \\
\hline Tobacco & 0.7 & 1.7 & -2.7 & 0.1 & 0.5 & 0.0 & 0.2 \\
\hline Textiles & -7.2 & -6.8 & -11.9 & 12.7 & 53.1 & -10.3 & 18.6 \\
\hline Wearing apparel & -19.5 & -19.8 & -21.3 & -1.5 & 48.5 & -11.2 & 41.4 \\
\hline Leather & -5.1 & -5.0 & -7.8 & -0.6 & 14.5 & -5.5 & 18.6 \\
\hline Wood & -1.0 & -5.5 & -12.8 & -3.8 & 0.4 & 12.2 & 1.9 \\
\hline Pulp \& paper & 3.5 & 2.4 & -3.4 & -2.9 & -6.5 & 3.4 & -8.2 \\
\hline Publishing \& printing & 2.7 & 3.2 & -2.0 & -1.4 & -4.8 & -1.1 & 1.1 \\
\hline Coke, refined petroleum & 0.2 & -0.1 & -1.7 & -1.4 & 0.0 & 17.8 & 0.0 \\
\hline Chemicals \& 35.3 & 25.7 & -2.1 & -11.7 & -3.7 & 7.9 & -44.8 & \\
\hline Rubber \& plastic & 0.6 & 2.4 & 2.2 & 3.4 & 4.1 & -10.1 & 5.1 \\
\hline Non-metallic mineral prod. & 4.5 & -1.3 & -0.1 & -5.2 & 3.4 & -6.2 & 3.5 \\
\hline Basic metals & -10.5 & 0.1 & 0.9 & -31.8 & -50.2 & 168.2 & -38.7 \\
\hline Metal products & 3.0 & -0.3 & -0.8 & 1.8 & 9.9 & -6.0 & 9.7 \\
\hline Machinery & 36.6 & 14.2 & 39.2 & -13.3 & -26.3 & -59.1 & -26.8 \\
\hline Office mach. \& computers & -30.2 & -10.5 & -10.4 & 24.6 & -15.6 & -13.8 & 38.3 \\
\hline Electrical machinery & 1.9 & 0.4 & 6.8 & -9.9 & -4.2 & -8.1 & 5.1 \\
\hline Radio, TV \& comm. equip. & -22.2 & -0.9 & 21.7 & 29.8 & -32.9 & -26.6 & -23.3 \\
\hline Medical, prec. \& opt. inst. & -0.9 & 13.3 & 0.6 & -22.6 & -10.3 & -8.9 & -13.2 \\
\hline Motor vehicles & 28.9 & -37.4 & 84.6 & 43.5 & 2.3 & -28.5 & -15.8 \\
\hline Other transport equipment & -5.4 & 24.2 & 4.4 & 24.6 & -27.1 & 24.2 & -2.7 \\
\hline Furniture; manuf. n.e.c. & -4.7 & -17.9 & -11.1 & 0.0 & 79.2 & -3.0 & 38.9 \\
\hline Degree of specialisation & 14.0 & 12.1 & 21.1 & 15.2 & 26.6 & 36.1 & 19.3 \\
\hline
\end{tabular}

Note: Results for the following sectors are not presented but they are taken in account in the calculations: Other mining \& quarrying, Recycling, Other business activities, Recreational, cultural \& sporting activities, Other service activities. The degree of specialisation is the standard error of the distribution of CTB. 
Table 10: Market shares in low-, medium-, and high-quality products in 2003 and change over the 1995-2003 period, (in \% and p.p.)

\begin{tabular}{l|cc|cc|cc|cc}
\hline \hline & \multicolumn{2}{|c|}{ down-market } & \multicolumn{2}{c|}{ mid-market } & \multicolumn{2}{c|}{ up-market } & \multicolumn{2}{c}{ all products } \\
& 2003 & $\Delta$ & 2003 & $\Delta$ & 2003 & $\Delta$ & 2003 & $\Delta$ \\
\hline EU25 & $\mathbf{1 2 . 9}$ & -1.8 & $\mathbf{2 0 . 0}$ & 2.0 & $\mathbf{3 2 . 3}$ & 3.1 & $\mathbf{2 1 . 7}$ & 0.8 \\
France & 1.8 & -0.2 & 2.3 & -0.3 & 4.2 & -0.1 & 2.8 & -0.2 \\
Germany & 3.0 & 0.0 & 5.5 & 0.6 & 11.3 & 0.4 & 6.6 & 0.2 \\
Italy & 2.1 & -0.7 & 2.6 & 0.1 & 3.8 & 0.6 & 2.8 & 0.0 \\
Poland & 0.4 & 0.1 & 0.2 & 0.2 & 0.1 & 0.1 & 0.3 & 0.1 \\
Spain & 0.9 & 0.1 & 1.0 & 0.1 & 0.8 & 0.2 & 0.9 & 0.1 \\
UK & 1.2 & -0.8 & 2.8 & 0.3 & 3.8 & 0.0 & 2.5 & -0.3 \\
Japan & 6.7 & -2.2 & 11.7 & -4.4 & 15.2 & -6.9 & 10.9 & -4.6 \\
Korea & 5.1 & -0.1 & 4.4 & 0.8 & 3.1 & -0.6 & 4.2 & -0.1 \\
Russia & 1.9 & 0.4 & 1.9 & 0.4 & 0.4 & 0.2 & 1.4 & 0.3 \\
India & 1.8 & 0.4 & 1.2 & 0.4 & 0.6 & 0.2 & 1.2 & 0.3 \\
Ukraine & 0.5 & 0.2 & 0.4 & 0.3 & 0.1 & 0.1 & 0.3 & 0.2 \\
USA & 12.0 & -3.7 & 13.6 & -4.1 & 17.9 & 0.2 & 14.5 & -2.4 \\
Chinese world & $\mathbf{2 5 . 9}$ & 6.2 & $\mathbf{1 2 . 3}$ & 5.9 & $\mathbf{6 . 4}$ & 2.0 & $\mathbf{1 5 . 7}$ & 5.0 \\
China & 20.4 & 8.1 & 8.2 & 4.6 & 3.7 & 1.5 & 11.6 & 5.2 \\
Hong Kong & 1.8 & -0.1 & 1.6 & 0.4 & 1.4 & 0.6 & 1.6 & 0.3 \\
Mediterranean & $\mathbf{1 . 9}$ & 0.5 & $\mathbf{1 . 8}$ & 0.3 & $\mathbf{1 . 4}$ & 0.4 & $\mathbf{1 . 7}$ & 0.4 \\
GCC & $\mathbf{0 . 8}$ & 0.2 & $\mathbf{0 . 7}$ & 0.2 & $\mathbf{0 . 3}$ & 0.0 & $\mathbf{0 . 6}$ & $\mathbf{0 . 1}$ \\
Mercosur & $\mathbf{3 . 0}$ & 0.1 & $\mathbf{4 . 2}$ & 0.6 & $\mathbf{0 . 9}$ & $\mathbf{- 0 . 1}$ & $\mathbf{2 . 4}$ & $\mathbf{0 . 1}$ \\
Brazil & 2.1 & 0.2 & 2.8 & 0.2 & 0.6 & 0.0 & 1.7 & 0.1 \\
ASEAN & $\mathbf{7 . 4}$ & -2.8 & $\mathbf{7 . 7}$ & -1.5 & $\mathbf{5 . 3}$ & -0.3 & $\mathbf{6 . 7}$ & -1.6 \\
RoW & $\mathbf{2 0 . 1}$ & 2.6 & $\mathbf{2 0 . 2}$ & -1.0 & $\mathbf{1 6 . 0}$ & 1.8 & $\mathbf{1 8 . 6}$ & 1.4 \\
\hline All & $\mathbf{1 0 0}$ & 0 & $\mathbf{1 0 0}$ & 0 & $\mathbf{1 0 0}$ & 0 & $\mathbf{1 0 0}$ & 0 \\
\hline \hline
\end{tabular}

up-market. Japan's specialisation appears to have shifted from up-market in 2002 to middle-market in 2003. However this change is entirely due to a slight decrease of the traded unit-value of the automobiles between 1500 and $3000 \mathrm{cc}$ exported to the American market. This evolution was sufficient for this flow to be classified as medium-market. And given its large weight in Japan's exports, the country "looses" its specialisation in the up-market in 2003. Meanwhile, developing countries reaffirmed themselves as exporters of both expensive and cheap products. By 2003 Chinese exports, for instance, represented more than one fifth of internationally traded low-market goods. At the same time, one third of exported high-quality products were produced in the EU.

At industry and quality level (see Tables 30 to 34 of Appendix $B$, the most striking feature is the collapse of the Japanese share in most industries, including the up-market part of those industries. The low-market was already largely abandoned by 1995, therefore these losses are more limited. The US managed to better resist to the emergence of new competitors, specifically in the up-market of some mature industries such as chemistry, metal, and paper products. The EU does not show up better resistance than the US in low-market, but by upgrading its exports it consolidated or built strongholds in the up-market of a vast majority of industries. Only agriculture, forestry, tobacco, office machinery and computers are in the up-market segment still dominated by the US. 
Cheptea, Gaulier, Sondjo and Zignago (2006), Study Report

Table 11: Decomposition of market share growth for Up-Market products 1995-2003, (in \%)

\begin{tabular}{|c|c|c|c|c|c|c|c|c|}
\hline & \multicolumn{4}{|c|}{ Volume } & \multicolumn{4}{|c|}{ Value } \\
\hline & $\begin{array}{l}\text { market } \\
\text { share } \\
\text { growth }\end{array}$ & $\begin{array}{l}\text { exports } \\
\text { perform. }\end{array}$ & $\begin{array}{l}\text { geo. } \\
\text { structure } \\
\text { effect }\end{array}$ & $\begin{array}{l}\text { sectoral } \\
\text { structure } \\
\text { effect }\end{array}$ & $\begin{array}{l}\text { market } \\
\text { share } \\
\text { growth }\end{array}$ & $\begin{array}{l}\text { exports } \\
\text { perform. }\end{array}$ & $\begin{array}{l}\text { geo. } \\
\text { structure } \\
\text { effect }\end{array}$ & $\begin{array}{l}\text { sectoral } \\
\text { structure } \\
\text { effect }\end{array}$ \\
\hline EU25 & 13.3 & 7.7 & -2.2 & 7.8 & 10.2 & 1.3 & -1.5 & 10.4 \\
\hline EU15 & 12.8 & 7.2 & -2.3 & 8.0 & 9.7 & 0.6 & -1.6 & 10.8 \\
\hline Austria & 34.6 & 28.9 & 1.1 & 4.6 & 22.5 & 18.2 & 1.2 & 3.1 \\
\hline Belgium \& Lux. & 14.8 & 10.6 & -3.1 & 7.2 & 15.4 & 2.2 & -2.0 & 15.2 \\
\hline Cyprus & -15.7 & 5.0 & -9.0 & -11.6 & -45.4 & -8.7 & -7.6 & -29.1 \\
\hline Czech Rep. & 19.2 & 28.0 & 6.0 & -14.8 & 7.9 & 11.7 & 6.6 & -10.4 \\
\hline Denmark & 5.7 & -2.2 & -8.3 & 16.1 & -2.2 & -2.1 & -8.4 & 8.4 \\
\hline Estonia & 117.4 & 142.4 & 1.4 & -26.4 & 147.4 & 170.8 & 3.2 & -26.6 \\
\hline Finland & 44.4 & 31.9 & 2.0 & 10.5 & 32.6 & 10.4 & 1.7 & 20.5 \\
\hline France & -8.6 & -12.6 & -1.9 & 5.9 & -10.8 & -19.6 & -1.4 & 10.2 \\
\hline Germany & 26.7 & 16.8 & -0.3 & 10.2 & 12.9 & 2.2 & 0.4 & 10.3 \\
\hline Greece & -40.2 & -43.9 & 12.2 & -8.6 & 10.2 & 9.5 & 9.5 & -8.8 \\
\hline Hungary & 55.4 & 48.6 & 8.9 & -2.1 & 80.8 & 101.6 & 7.2 & -28.0 \\
\hline Ireland & 59.1 & 43.1 & -6.2 & 22.2 & 108.8 & 69.8 & -7.3 & 46.2 \\
\hline Italy & 2.1 & 13.3 & -2.2 & -9.0 & 2.8 & 13.7 & -1.4 & -9.5 \\
\hline Latvia & 26.5 & 31.4 & -1.4 & -3.6 & 45.7 & 50.7 & 2.5 & -7.5 \\
\hline Lithuania & -53.5 & -21.9 & -4.4 & -27.3 & -31.6 & 2.8 & -3.5 & -30.9 \\
\hline Malta & -52.7 & -89.8 & 8.1 & 29.0 & 14.2 & -29.2 & 15.8 & 27.7 \\
\hline Netherlands & 7.7 & 4.4 & -5.7 & 9.0 & 10.5 & 8.5 & -3.7 & 5.7 \\
\hline Poland & 81.5 & 100.2 & -8.8 & -9.9 & 45.3 & 65.2 & -1.9 & -18.0 \\
\hline Portugal & -8.2 & 7.7 & -9.1 & -6.8 & -6.0 & 14.7 & -7.5 & -13.2 \\
\hline Slovakia & 16.0 & 15.3 & 5.2 & -4.5 & 35.2 & 24.8 & 8.1 & 2.3 \\
\hline Slovenia & 23.0 & 5.1 & 19.8 & -1.8 & 3.7 & -9.6 & 17.1 & -3.8 \\
\hline Spain & 13.9 & 27.8 & -6.6 & -7.4 & 6.8 & 20.6 & -6.2 & -7.6 \\
\hline Sweden & -14.5 & -20.8 & -3.3 & 9.6 & -1.0 & -8.2 & -2.2 & 9.3 \\
\hline$U K$ & 0.9 & -9.6 & -4.1 & 14.6 & 3.1 & -16.4 & -2.6 & 22.0 \\
\hline USA & -21.9 & -32.8 & 0.9 & 10.0 & -5.4 & -11.5 & -1.4 & 7.4 \\
\hline Japan & -22.4 & -20.8 & 3.8 & -5.4 & -25.4 & -29.6 & 5.4 & -1.3 \\
\hline China & 83.9 & 146.9 & -14.4 & -48.7 & 64.2 & 128.8 & -14.4 & -50.2 \\
\hline Brazil & 62.8 & 77.6 & -10.6 & -4.2 & 44.7 & 65.4 & -12.4 & -8.2 \\
\hline Russia & -159.3 & -103.8 & 12.2 & -67.6 & -100.3 & -68.2 & 20.4 & -52.5 \\
\hline India & 63.4 & 95.7 & -1.4 & -31.0 & 37.7 & 81.6 & 0.0 & -43.9 \\
\hline
\end{tabular}

Note: Trade flows are classified into three large quality ranges according to the principle that high quality products (up-market) are also the more expensive ones. Details are explained in section 5.1.

China obtained spectacular market share gains in textile, clothing, electrical, electronic and various other industries (toys, etc.). Almost all manufactured goods exported by the country, at all quality levels, have been concerned by this trend. Still, the largest gains are in the low-market segment, where China acquired the leadership in half of the industries (see Table 30 and upper half of Figure 7 of Appendix B). 
European Positioning in the International Division of Labour

Table 12: CTB by quality of traded goods in 2003 and 1995

\begin{tabular}{lcrrrrrr}
\hline \hline & EU25 & USA & Japan & Korea & India & Russia & China \\
\hline & \multicolumn{7}{c}{2003} \\
Low-market & -56.6 & -47.1 & -18.9 & 74.8 & 73.2 & 14.1 & 182.7 \\
Mid-market & -15.8 & 5.2 & 30.1 & -19.2 & -43.8 & 39.3 & -57.0 \\
Up-market & 75.8 & 20.2 & -0.9 & -55.4 & -36.9 & -66.5 & -88.9 \\
nc & -3.4 & 21.7 & -10.3 & -0.3 & 7.6 & 13.1 & -36.8 \\
\hline Degree of specialisation & 67.8 & 35.3 & 24.8 & 67.2 & 65.6 & 55.2 & 148.5 \\
\hline & \multicolumn{7}{c}{1995} \\
Low-market & -36.5 & -36.4 & -16.0 & 108.4 & 49.9 & 59.3 & 109.7 \\
Mid-market & -20.8 & 25.1 & 23.9 & -39.0 & -29.6 & 42.6 & -41.3 \\
Up-market & 61.0 & 10.1 & -4.6 & -68.5 & -61.3 & -112.5 & -63.4 \\
nc & -3.7 & 1.3 & -3.3 & -0.9 & 41.0 & 10.6 & -5.0 \\
\hline Degree of specialisation & 52.3 & 32.1 & 20.5 & 94.8 & 57.3 & 94.7 & 94.2 \\
\hline \hline
\end{tabular}

Note: See notes of Table 9 nc stands for not classified. When quantities are not available the breakdown by quality ranges in not possible.

The good performance of exports of Korea and others countries from East Asia was due to their withdrawal from markets segments where the competition with Chinese firms was the more severe. Korea moved away from textile, leather, and wearing apparel to become an important player in car making, electric, electronic and mechanic goods. In most of the cases Korea avoided specialisation in low-market (see Table 30 and lower half of Figure 7 of Appendix B.

Thus, in 2003 we end-up with a shared leadership in many industries, with China dominating the lowmarket and the EU consolidating its positions in the up-market.

The EU displayed a very good performance in the up-market segments. It managed to increase its market share thanks to a favourable sectoral specialisation but also to a positive export performance (Tables 11 and 12 ). Other members of the Triad, on the contrary, have shrunk their market shares on this segment, both in terms of volumes and values. If one is to attribute the upsurge in quality of goods to an increase in their price, up-market goods can also be labelled as high-quality products. However, the segmentation of markets into up-, middle-, and low- being judged exclusively on the unit-values of internationally traded goods, we automatically exclude all sources of products differentiation not reflected in prices. Thus, the good performance of European exports, especially compared to that of other industrialised countries, depicted in Table 11 should be rather interpreted that the EU is more successful in selling its products at higher prices.

\section{The Performance of Exported Products by the Level of Technology}

\subsection{The Definition of High-Tech Products}

The definition of high-technology products is usually based on measures of technological intensity in OECD countries, such as R\&D expenditures on the value added, or R\&D on the level of production. On the basis of this definition, two types of classifications of high-technology products emerge: 
1. at a broad category level, when the indexes of high-tech content are computed at branch level, and all the products within a high-tech branch are considered as intensive in high-technology;

2. at a detailed product level, the indexes of high-tech content being computed for each product within a broad category.

The first methodology is the most widely used in the literature. For instance, the latest OECD classification based on technology indicators groups manufacturing branches, given by the ISIC Rev.3, classification at the 2- or 3-digit level, into four technological levels: high-technology, medium-high-technology; medium-lowtechnology; and low technology. In this classification high-technology industries include all products from to the following branches:

\begin{tabular}{ll}
\hline ISIC code & Industry \\
\hline 353 & aircraft and spacecraft \\
2423 & pharmaceuticals \\
30 & office, accounting, and computing machinery \\
32 & radio, TV and communication equipment \\
33 & medical, precision and optical instrument \\
\hline
\end{tabular}

In the same way, according to the World Development Indicators database of the World Bank, hightechnology exports include all exports of the following branches: aerospace, computers, pharmaceuticals, scientific instruments, and electrical machinery. Note, that this methodology introduces an important selection bias, since not all products from a "high-technology" industry necessarily have a high technology content. Likewise, some products in industries with low technology intensity may well incorporate a high degree of technological sophistication.

For these reasons, a second classification methodology of goods according to the technology level has been developed. It defines first large high-tech sectors or branches, and then selects within each of them only products with a high content of R\&D. The definition of high-techology products used in CEPII studies refers to this second approach (Fontagné et alii, 1999). The following ten industries have been selected as high-tech with this methodology:

\begin{tabular}{ll}
\hline aerospace & electrical machinery \\
computers, office machinery & chemicals \\
electronics-communications & other transport equipment \\
pharmaceuticals & non-electrical machinery \\
scientific instruments & weapons \\
\hline
\end{tabular}

In the second step, within these broad categories, a list of 252 products (at the 6-digits HS level) are identified as high-tech. This methodology solves only partially the bias discussed above. Although it examines each product whether it has a high-technology content or not, only those from branches that are considered a priori as intensive in high-technology are taken into account. High-technology products belonging to non technological branches are, therefore, implicitly considered as non-technological.

\subsection{Exports Performance by Technology Level}

Market shares depicted in Table 13 and Figures 4 and 5 show that high-technology industries are not any longer a quasi monopoly of industrialised countries. China in first place, but also other emerging countries from Asia, invested largely in these industries, and managed to build strongholds in the lower range of these 
European Positioning in the International Division of Labour

Table 13: Market shares in high technology goods and change 1995-2003, (in \% and p.p.)

\begin{tabular}{|c|c|c|c|c|c|c|c|c|}
\hline & \multicolumn{2}{|c|}{ Low Market } & \multicolumn{2}{|c|}{ Mid Market } & \multicolumn{2}{|c|}{ Up Market } & \multicolumn{2}{|c|}{ All } \\
\hline & 2000 & $\Delta$ & 2000 & $\Delta$ & 2000 & $\Delta$ & 2000 & $\Delta$ \\
\hline EU25 & 13.0 & -2.9 & 23.0 & 0.5 & 28.3 & -1.2 & 21.4 & -2.0 \\
\hline France & 2.0 & 0.1 & 4.5 & 0.6 & 6.6 & -1.9 & 4.4 & -0.9 \\
\hline Germany & 2.1 & -1.3 & 6.8 & 0.8 & 8.1 & 1.4 & 5.5 & 0.1 \\
\hline Italy & 1.4 & -0.7 & 1.6 & 0.0 & 1.3 & -0.5 & 1.4 & -0.5 \\
\hline Poland & 0.1 & 0.0 & 0.1 & 0.0 & 0.0 & 0.0 & 0.1 & 0.0 \\
\hline Spain & 0.5 & -0.1 & 0.4 & -0.4 & 0.3 & -0.1 & 0.4 & -0.1 \\
\hline UK & 2.3 & -1.3 & 3.2 & -1.0 & 3.8 & -0.3 & 3.1 & -0.8 \\
\hline Japan & 8.0 & -6.9 & 13.8 & -16.3 & 11.2 & -7.7 & 10.5 & -9.5 \\
\hline Korea & 3.1 & -0.7 & 7.6 & 4.7 & 7.5 & 3.6 & 5.9 & 2.2 \\
\hline Russia & 1.4 & 1.0 & 1.5 & 1.4 & 0.9 & 0.9 & 1.2 & 1.0 \\
\hline India & 0.8 & 0.4 & 0.3 & -0.2 & 0.2 & 0.0 & 0.5 & 0.1 \\
\hline Ukraine & 0.1 & 0.1 & 0.2 & 0.1 & 0.0 & 0.0 & 0.1 & 0.1 \\
\hline USA & 17.2 & -3.2 & 17.0 & -2.4 & 20.2 & -7.1 & 18.5 & -4.9 \\
\hline Chinese world & 27.9 & 15.9 & 7.1 & 4.1 & 3.9 & 2.8 & 13.8 & 8.6 \\
\hline China & 24.4 & 14.6 & 5.4 & 3.9 & 2.8 & 2.5 & 11.7 & 7.9 \\
\hline Hong Kong & 3.5 & 1.4 & 1.7 & 0.3 & 1.1 & 0.2 & 2.1 & 0.7 \\
\hline Mediterranean & 0.8 & 0.2 & 1.2 & 0.6 & 0.8 & 0.1 & 0.9 & 0.2 \\
\hline GCC & 0.3 & 0.2 & 0.4 & 0.2 & 0.7 & 0.4 & 0.5 & 0.3 \\
\hline Mercosur & 0.5 & -0.1 & 2.3 & 1.7 & 0.8 & 0.5 & 0.9 & 0.5 \\
\hline ASEAN & 9.4 & -4.6 & 10.3 & -2.0 & 10.6 & 4.7 & 10.1 & 0.1 \\
\hline RoW & 17.5 & 0.6 & 15.5 & 7.6 & 14.8 & 3.2 & 16.0 & 3.4 \\
\hline All & 100 & 0 & 100 & 0 & 100 & 0 & 100 & 0 \\
\hline
\end{tabular}

markets. Mexico, in the context of the NAFTA, also acquired important market shares in high-tech products. It benefited to a large degree from the important investments of American and European firms.

Meanwhile, Japan lost large market shares to Chinese and East-Asian competitor. A process of regionalisation was, therefore, at work in both America and Asia. Losses by industrialised countries in each zone were compensated by gains obtained by emerging economies. In East Asia, Korea and ASEAN countries resisted to China's surge by upgrading their exports. Their losses in the low-market were more than offset by large gains in up-market products.

The EU showed better resistance than other countries in the Triad, but still lost ground to emerging countries. The positive sectoral effect for EU in the decomposition of global market share growth (Table 3) is obtained as the sum of almost equal effects for high-technology and other products, but in both cases up-market segments accounted for the largest part of theses effects (see Tables 35 and 36 of Appendix B).

We decompose separately the market share growth of high-tech products according to the methodology described in section 2.1. and show results in Table 14. Large disparities between the evolution of overall market shares (Table 13), and of the ones obtained only for persisting trade flows (Table 14) reflect the emergence and the vanishing of large country-partner-product specific trade flows within this segment. The EU managed to preserve its global share on high-technology product only due to the creation of new trade flows, i.e. 
Figure 4: Evolution of Market Shares in High-technology Up-market Goods

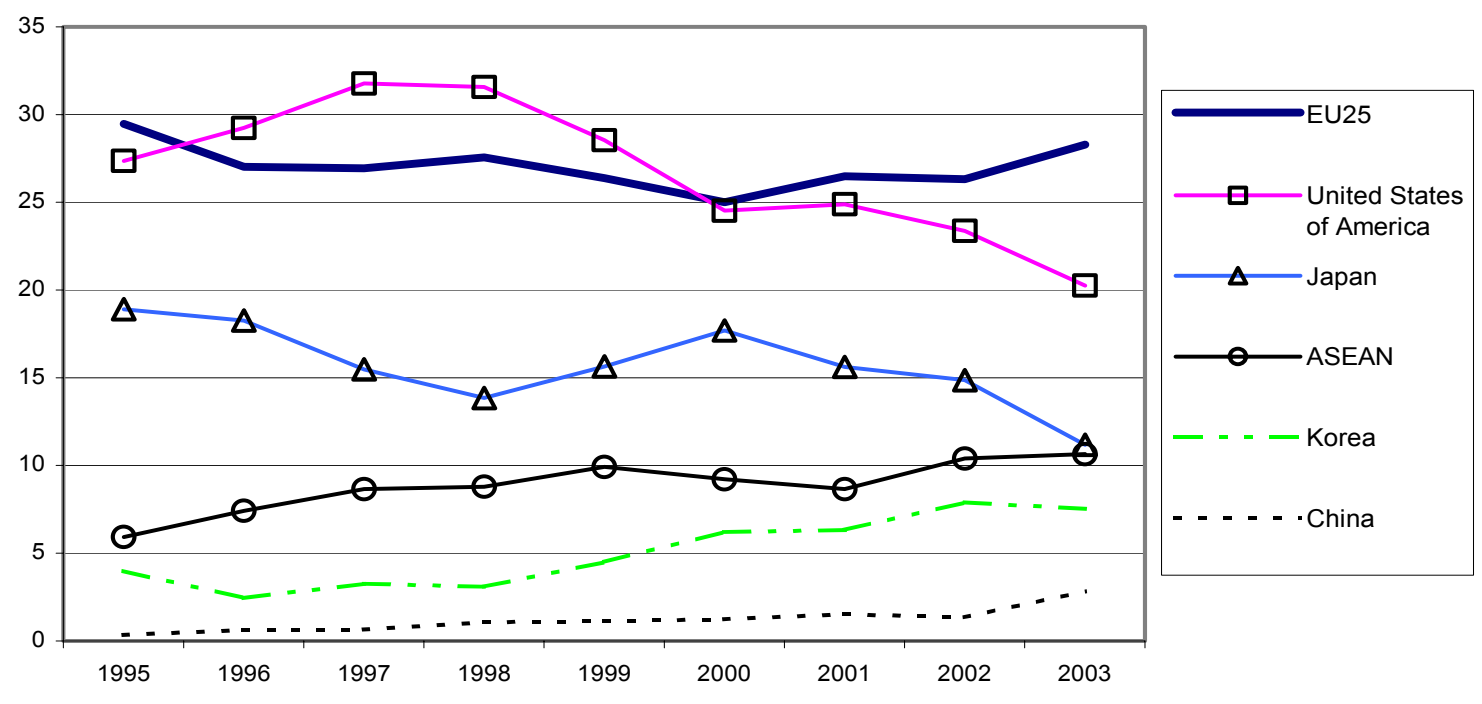

Figure 5: Evolution of Market Shares in High-technology Low-market Goods

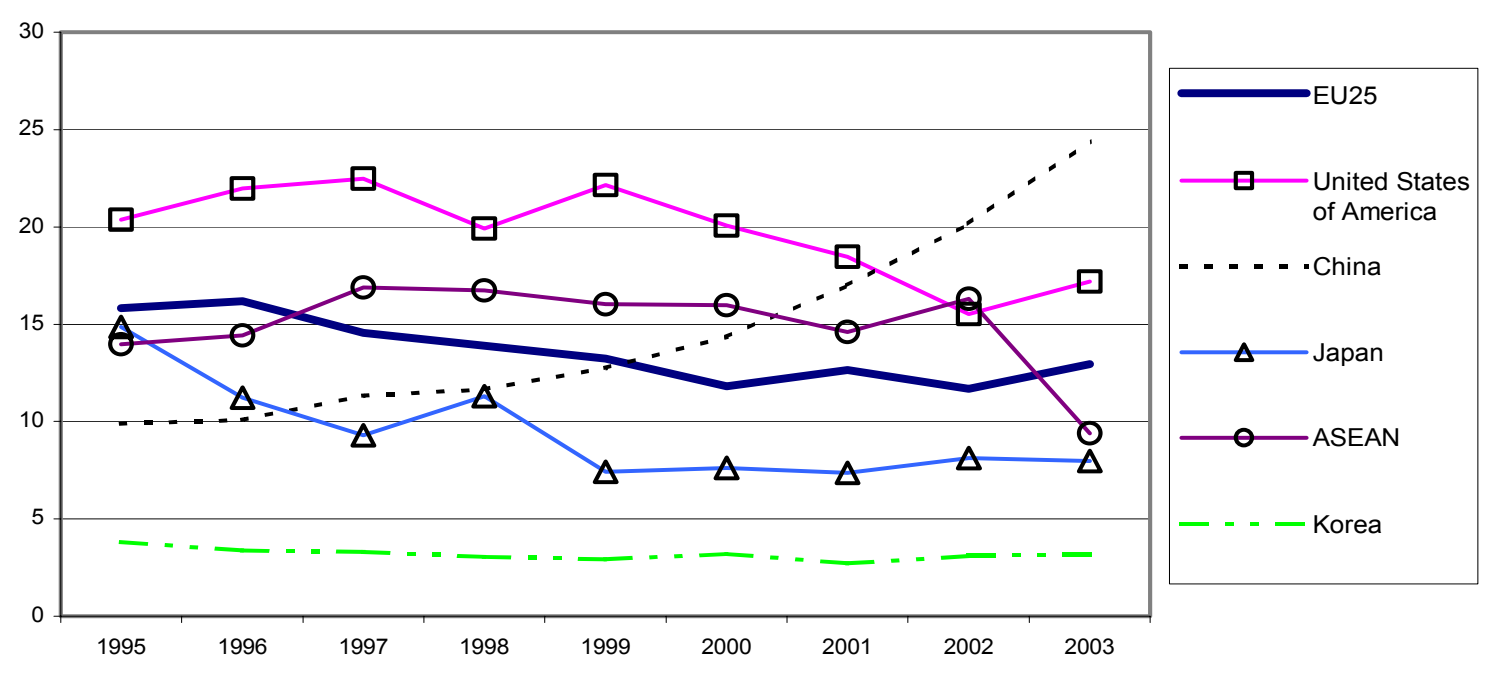


European Positioning in the International Division of Labour

Table 14: Decomposition of market share growth for high-technology products 1995-2003, (in \%)

\begin{tabular}{|c|c|c|c|c|c|c|c|c|}
\hline & \multicolumn{4}{|c|}{ Volume } & \multicolumn{4}{|c|}{ Value } \\
\hline & $\begin{array}{l}\text { market } \\
\text { share } \\
\text { growth }\end{array}$ & $\begin{array}{l}\text { exports } \\
\text { perform. }\end{array}$ & $\begin{array}{l}\text { geo. } \\
\text { structure } \\
\text { effect }\end{array}$ & $\begin{array}{l}\text { sectoral } \\
\text { structure } \\
\text { effect }\end{array}$ & $\begin{array}{l}\text { market } \\
\text { share } \\
\text { growth }\end{array}$ & $\begin{array}{l}\text { exports } \\
\text { perform. }\end{array}$ & $\begin{array}{l}\text { geo. } \\
\text { structure } \\
\text { effect }\end{array}$ & $\begin{array}{l}\text { sectoral } \\
\text { structure } \\
\text { effect }\end{array}$ \\
\hline EU25 & -31.4 & -36.6 & -3.5 & 8.7 & -9.9 & -24.7 & 0.0 & 14.8 \\
\hline EU15 & -33.1 & -38.5 & -3.8 & 9.1 & -12.3 & -27.2 & -0.2 & 15.1 \\
\hline Austria & -14.3 & -24.6 & -1.0 & 11.3 & 48.0 & 24.4 & 5.7 & 17.9 \\
\hline Belgium \& Lux. & -67.6 & -64.1 & -1.4 & -2.1 & -49.7 & -57.5 & 5.5 & 2.3 \\
\hline Cyprus & -8.3 & -56.2 & 5.1 & 42.8 & -43.2 & -68.3 & 34.9 & -9.8 \\
\hline Czech Rep. & 15.9 & 81.3 & -8.1 & -57.3 & 101.9 & 145.4 & -5.7 & -37.8 \\
\hline Denmark & -12.6 & -52.8 & -12.3 & 52.5 & 7.7 & -39.0 & -1.6 & 48.2 \\
\hline Estonia & 2.0 & -0.3 & -7.8 & 10.1 & -27.5 & -47.7 & 12.7 & 7.4 \\
\hline Finland & 86.3 & 55.6 & 8.7 & 22.0 & 76.2 & 24.4 & 8.4 & 43.4 \\
\hline France & -47.2 & -55.5 & -4.0 & 12.4 & -18.2 & -39.3 & -3.1 & 24.1 \\
\hline Germany & -17.8 & -20.9 & -1.1 & 4.3 & 3.6 & -9.4 & 2.8 & 10.2 \\
\hline Greece & 17.6 & 39.0 & 15.4 & -36.7 & 36.7 & 37.7 & 32.6 & -33.6 \\
\hline Hungary & 107.3 & 117.6 & -1.7 & -8.7 & 143.4 & 131.8 & 7.1 & 4.6 \\
\hline Ireland & 64.5 & 60.1 & -16.8 & 21.2 & 75.2 & 82.4 & -10.4 & 3.2 \\
\hline Italy & -41.6 & -39.9 & -2.5 & 0.8 & -32.2 & -36.2 & 0.6 & 3.5 \\
\hline Latvia & 31.7 & 25.9 & 25.0 & -19.1 & 125.3 & 69.5 & 58.5 & -2.8 \\
\hline Lithuania & -119.6 & -94.4 & 25.8 & -51.0 & -102.0 & -108.3 & 52.0 & -45.7 \\
\hline Malta & 167.5 & 167.3 & -16.9 & 17.2 & 171.4 & 148.2 & 9.3 & 13.9 \\
\hline Netherlands & -38.0 & -31.6 & -3.9 & -2.5 & -30.3 & -29.0 & 2.0 & -3.3 \\
\hline Poland & 20.4 & 13.1 & 7.5 & -0.1 & 40.8 & 20.4 & 20.6 & -0.2 \\
\hline Portugal & 55.5 & 135.6 & -23.9 & -56.1 & 35.7 & 124.5 & -33.0 & -55.9 \\
\hline Slovakia & -182.5 & -117.2 & 6.2 & -71.6 & -136.1 & -28.4 & 6.9 & -114.6 \\
\hline Slovenia & 10.5 & 12.8 & 15.6 & -17.9 & 42.6 & 10.4 & 39.1 & -6.9 \\
\hline Spain & -22.3 & -4.6 & -5.3 & -12.4 & -27.4 & -16.9 & -7.4 & -3.1 \\
\hline Sweden & -76.5 & -82.7 & -0.2 & 6.5 & -55.1 & -79.3 & -1.1 & 25.4 \\
\hline$U K$ & -53.5 & -56.6 & -8.7 & 11.8 & -30.9 & -39.9 & -2.6 & 11.6 \\
\hline USA & -5.3 & -38.4 & 21.6 & 11.4 & -23.5 & -47.2 & 7.2 & 16.4 \\
\hline Japan & -74.3 & -43.6 & -7.3 & -23.4 & -69.0 & -37.4 & -3.1 & -28.5 \\
\hline China & 126.4 & 158.5 & -16.8 & -15.4 & 124.6 & 163.0 & -13.2 & -25.3 \\
\hline Brazil & 48.2 & 80.9 & -12.5 & -20.2 & 102.9 & 150.5 & -13.3 & -34.2 \\
\hline Russia & -28.7 & -25.6 & 9.4 & -12.5 & 75.4 & 61.1 & 35.8 & -21.6 \\
\hline India & 47.0 & 70.1 & -7.3 & -15.8 & 1.0 & 21.5 & 0.0 & -20.5 \\
\hline
\end{tabular}

new exported products, and/or new trade partners. A similar reorientation of American and Japanese exports prevented these countries from loosing even larger market shares. Differently from industrialised countries, China, Brazil, and Russia expanded their shares in high-technology sectors by selling more on already established trade relations.

Table 15 reveals the fact that, differently from other industrialised countries, the EU is not specialised in high technology goods (a negative CTB indicator). Its comparative disadvantage in the high-technology sector augmented since 1995, but the EU managed to reinforce its specialisation in high-quality products within this sector. The US maintained its large specialisation in technological goods, although it was particularly high in 
Table 15: CTB for high technology products by quality in 2003

\begin{tabular}{l|l|rrrrrrr}
\hline \hline & Quality & EU25 & USA & Japan & Korea & Russia & India & China \\
\hline \multirow{3}{*}{ High } & all & -12.7 & 28.9 & 3.7 & 29.5 & 0.9 & -44.4 & -8.9 \\
\cline { 2 - 8 } technology & nc & -4.0 & 4.1 & -0.4 & -0.3 & -0.2 & -0.9 & -3.5 \\
& Low-market & -11.4 & 3.5 & 4.2 & 3.7 & 6.2 & -17.8 & 38.8 \\
& Mid-market & -2.0 & 6.7 & 6.1 & 7.8 & -2.0 & -7.1 & -15.4 \\
& Up-market & 4.8 & 14.6 & -6.1 & 18.4 & 6.8 & -18.6 & -28.7 \\
\hline \multirow{5}{*}{ Others } & all & 12.7 & -28.9 & -3.7 & -29.5 & -10.9 & 44.4 & 8.9 \\
\cline { 2 - 8 } & nc & 0.6 & 17.7 & -9.9 & 0.0 & 13.4 & 8.5 & -33.3 \\
& Low-market & -45.2 & -50.6 & -23.1 & 71.2 & 7.8 & 90.9 & 144.0 \\
& Mid-market & -13.8 & -1.4 & 24.0 & -26.9 & 41.3 & -36.7 & -41.6 \\
& Up-market & 71.1 & 5.5 & 5.2 & -73.7 & -73.3 & -18.3 & -60.2 \\
\hline \hline
\end{tabular}

Note: nc stands for not classified. When quantities are not available the breakdown by quality ranges in not possible.

the late 1990s (see Table 16. American firms, however, lost ground on up-market high-tech products. One of the most spectacular evolution in this sector was reached by Korea. By increasing its specialisation in the up-market (high-price/high-quality) segments, the country managed to transform its large 1995 disadvantage in high-technology goods into a strong comparative advantage in 2002-2003. Nevertheless, it conserved its specialisation in low-quality products in the rest of the economy.

Table 16: Evolution of Specialisation (CTB) in High-technology Goods

\begin{tabular}{r|rrrrrr}
\hline \hline \multicolumn{7}{|c}{ All high-technology products } \\
\hline & EU25 & USA & Japan & Korea & China & India \\
\hline 1995 & -10.6 & 29.3 & 21.0 & -24.2 & -16.6 & -36.8 \\
1996 & -11.8 & 43.1 & 15.2 & -25.7 & -23.0 & -36.3 \\
1997 & -14.4 & 41.2 & 15.5 & -0.2 & -19.1 & -35.6 \\
1998 & -14.1 & 41.2 & 14.9 & -4.3 & -22.6 & -32.5 \\
1999 & -16.6 & 32.8 & 5.2 & 4.2 & -9.4 & -23.8 \\
2000 & -14.8 & 24.7 & 10.4 & 9.4 & -5.0 & -26.7 \\
2001 & -14.6 & 25.4 & 15.8 & 11.2 & -10.6 & -29.9 \\
2002 & -12.5 & 27.1 & 8.1 & 26.8 & -18.4 & -33.5 \\
2003 & -12.7 & 28.9 & 3.7 & 29.5 & -8.9 & -44.4 \\
\hline \multicolumn{7}{|c}{ Up-Market high-technology products } \\
\hline & EU25 & USA & Japan & Korea & China & India \\
\hline 1995 & 2.2 & 21.8 & -3.4 & -12.1 & -16.3 & -8.1 \\
1996 & -2.2 & 28.3 & -4.2 & -19.5 & -24.4 & -16.2 \\
1997 & -1.6 & 25.8 & -3.6 & -5.5 & -22.2 & -12.8 \\
1998 & 4.2 & 21.1 & -4.2 & -9.6 & -23.8 & -8.4 \\
1999 & 0.2 & 22.2 & -3.7 & -0.3 & -18.9 & -7.7 \\
2000 & 0.0 & 14.8 & 3.4 & 7.6 & -18.1 & -7.2 \\
2001 & 0.9 & 15.6 & 7.2 & 10.3 & -18.0 & -9.6 \\
2002 & 4.9 & 15.5 & -1.8 & 22.5 & -27.8 & -15.2 \\
2003 & 4.8 & 14.6 & -6.1 & 18.4 & -28.7 & -18.6 \\
\hline \hline
\end{tabular}


European Positioning in the International Division of Labour

\section{Conclusion}

During the last few years, world trade has been marked by the emergence of new partners from the South. Developing countries have recorded remarkable gains in global market share, and have affirmed themselves not just as suppliers of the North but also as rapidly expanding import markets. Faced with the enhanced competitiveness of developing countries' products, industrialised economies have experienced increasing difficulties in preserving their market shares. The present study analyses the positioning of the EU and its Member States in the extra-EU market over the 1995-2003 period, by paying close attention to the geographical and the sectoral specialisation of European exports. Methodologically, it relies on an analysis of market shares and comparative advantages. This work draws on a highly detailed data base, making possible the analysis of performances on specific segments of the world market: high-technology goods, low-, middle- and up-market within each industry, stages of production, etc. These various dimensions are considered separately and jointly.

Gains or losses in world market share of individual countries are often considered as an index of their trade competitiveness. However, an inherited specialisation in leading export sectors and goods-positioning in the most dynamic markets may generate additional market share without any effort on behalf of the exporting country itself. We employ a transformed, shift-share methodology to separate the effect of the sectoral and geographical structure of exports from the export performance effect, reflecting countries' capacity to respond to changes in global demand and to improve the competitiveness of their products.

The overall EU market share has eroded during the last years, due to the poor performance of its largest members (with the exception of Germany), and despite the favourable sectoral breakdown of its exports. Still, results vary considerably across different markets. Thus, European countries displayed a much better performance in up-market segments, i.e. for goods with prices exceeding the world average by at least $25 \%$. During the considered period, the EU reinforced and acquired leadership in up-market products in a large number of industries, ranging from leather and clothing to machinery and automobiles.

Meanwhile, European countries suffered important market share losses in the high-technology sector. Moreover, the revealed comparative advantage indicator, computed as the contribution of individual sectors or industries to the trade balance, shows that the EU, contrary to the US and Japan, is no longer specialised in high-technology products. This result is explained by the large and deepening disadvantage of EU countries in down-market high-tech products, such as computer devices. Nevertheless, the EU has maintained and even reinforced its comparative advantage in up-market (high-price/high-quality) high-technology products.

\section{References}

- Balassa B. (1965), "Trade liberalisation and revealed comparative advantage", The Manchester School of Economics and Social Studies 33: 99-123.

- CEPII (2004), "European industry's place in the International Division of Labour : situation and prospects", CEPII report for the European Commission

(http://www.cepii.fr/anglaisgraph/communications/pdf/2004/150704/ditreport.pdf).

- Cheptea A., G. Gaulier and S. Zignago (2005) "World Trade Competitiveness: A Disaggregated View by Shift-Share Analysis", CEPII Working Paper N²005-23.

- Diewert W.E. (1993) "Exact and Superlative Index Numbers", Journal of Econometrics 4 (1976), 114145. Reprinted in Essays in Index Number Theory, (Vol. 1), W. E. Diewert and A. O. Nakamura, eds. Elsevier Science Publishers, Amsterdam. 
- Feenstra R. and A. Rose (2000), "Putting Things in Order: Trade Dynamics and Product Cycles", Review of Economics and Statistics, August 2000, v. 82, iss. 3, pp. 369-82.

- Fontagné L., M. Freudenberg and D. Ünal-Kesenci (1999), "Haute technologie et échelles de qualité : de fortes asymétries en Europe", CEPII Working Paper N¹999-08.

- Jayet H. (1993), Analyse spatiale quantitative : une introduction, Economica, Paris

\section{A Data description}

\section{A1. The BACI database}

International trade statistics can only be used to carry out detailed studies related to recent developments in economic theory, at the cost of extensive, fastidious work on treating data from numerous, heterogeneous sources. To meet these difficulties, the CEPII has constructed a database on international trade that brings together and renders consistent various levels of analyses and classifications, drawing on the most detailed information available. The particular goal is to put forward a characterisation of trade flows in terms of trade types (one-way trade, cross-trade in similar products, cross-trade in vertically differentiated products), product ranges, technological levels and stages of production.

BACI draws on the UN's trade database COMTRADE and renders consistent trade flow by reconciling information reported by the exporter and the importer (when both are available). This harmonisation of mirror flows is done for value and quantities. The latter statistics are converted into tons before (avoid if possible) when necessary, making possible the computation of homogeneous unit values. A detailed description of the data is available at: http://www.cepii.fr/anglaisgraph/bdd/baci.htm

BACI is based on COMTRADE database and covers more than 200 countries and 5000 products, between 1993 and 2003. Trade flows are reported to United Nations in value and quantity by both exporting and importing country (mirror flows, when available) and harmonised. Indeed, given the huge discrepancies between reported mirror flows, trade data have to be harmonised (at the 6-digit level, the gap between mirror flows exceeds $100 \%$ for half of the observations in COMTRADE). Original procedures have been developed to harmonise data: Evaluation of the quality of country declarations, conversion in tons of the other units of quantities exchanged and evaluation of CIF rates. In COMTRADE, import values are reported CIF (cost, insurance and freight) and the exports are reported FOB (free on board). In order to remove CIF, freight costs have to be estimated.

The harmonisation proceeds in two steps: We first calculate indicators of quality of import and export declarations for each country, which are used as weights in a second step, when averaging the mirror flows to get the harmonised flow. In order to evaluate the quality of the declarations of one export country $i$, we use a measure of distance between the distribution of the ratios of mirror flows (log of reported export from $i$ to $j$ on reported import of $j$ from $i$ ) of this country with the distribution of these ratios for all exporters (and symmetrically for the quality of import declarations). As far as the quality of import declarations is concerned, Italy ranks first, followed by Switzerland and the majority of industrialised countries. , Some emerging and developing countries get good ranking, in particular Latin American as well as East-European countries. Import and export quality indicators are transformed in order to sum to 1 and be used as weights.

\section{A2. The sample}

We consider trade flows from 1995 to 2003 between all countries listed in the UN-COMTRADE database. Trade flows inferior to USD 10,000, or 2 tons are excluded. 
We employ a very detailed disaggregation of trade flows across products: at the 6-digit HS level, accounting for about 5000 products or groups of products. We exclude, however, a number of "problematic" product groups, among which oil products.

Table 17: List of excluded products

\begin{tabular}{l|l}
\hline \hline HS chapter & Description of products \\
\hline 25 & Salt. sulphur. earth \& ston. plastering mat. lime \& cem. \\
26 & Ores, slag and ash. \\
27 & Mineral fuels, oils \& product of their distillation etc. \\
97 & Works of art, collectors pieces and antiques. \\
98 & Special Classification Provisions \\
99 & Special Transaction Trade. \\
\hline \hline
\end{tabular}

Table 18: ISO codes of European countries

\begin{tabular}{ll|ll|ll}
\hline \hline ISO code & Country & ISO code & Country & ISO code & Country \\
\hline AUT & Austria & EST & Estonia & HUN & Hungary \\
BEL & Belgium and Lux. & FIN & Finland & IRL & Ireland \\
CYP & Cyprus & FRA France & ITA & Italy & \\
CZE & Czech Republic & DEU & Germany & LVA & Latvia \\
DNK & Denmark & GRC & Greece & LTU & Lithuania \\
MLT & Malta & NLD & Netherlands & POL & Poland \\
PRT & Portugal & SVK & Slovakia & SVN & Slovenia \\
ESP & Spain & SWE & Sweden & GBR & United Kingdom \\
\hline \hline
\end{tabular}

\section{A3. Classification by Production Stages According To the BEC}

In this study, the data are aggregated according to the BEC classification (Broad Economic Categories of the United Nations of production stages). The BEC reclassifies the Standard International Trade Classification (SITC, Rev. 3) headings on the basis of the principal use of the products. It converts foreign trade data into categories of final or intermediate use, such us capital goods, intermediate goods or consumer goods, following the usage in the System of National Accounts (SNA). We grouped BEC items into five stages of production as follows: 
Table 19: BEC classification of products

\begin{tabular}{|c|c|c|c|}
\hline 3 stages & 5 stages & $\begin{array}{l}\text { BEC } \\
\text { code }\end{array}$ & BEC title \\
\hline $\begin{array}{l}\text { Primary } \\
\text { goods }\end{array}$ & Primary goods & $\begin{array}{l}111 \\
21 \\
31\end{array}$ & $\begin{array}{l}\text { Food and beverages mainly for industry } \\
\text { Industrial supplies, n.e.s., primary } \\
\text { Fuels and lubricants, primary }\end{array}$ \\
\hline \multirow[t]{2}{*}{$\begin{array}{l}\text { Intermediate } \\
\text { goods }\end{array}$} & $\begin{array}{l}\text { Transformed } \\
\text { (semi-finished) goods }\end{array}$ & $\begin{array}{l}121 \\
22 \\
322\end{array}$ & $\begin{array}{l}\text { Food and beverages, processed, mainly for industry } \\
\text { Industrial supplies, n.e.s., processed } \\
\text { Fuels and lubricants, processed }\end{array}$ \\
\hline & Parts \& components & 53 & $\begin{array}{l}\text { Parts \& components of capital goods, except transport } \\
\text { equipment } \\
\text { Parts and accessories of transport equipment }\end{array}$ \\
\hline \multirow[t]{2}{*}{$\begin{array}{l}\text { Final } \\
\text { goods }\end{array}$} & Capital goods & $\begin{array}{ll}41 \\
521\end{array}$ & $\begin{array}{l}\text { Capital goods except transport equipment } \\
\text { Other industrial transport equipment }\end{array}$ \\
\hline & Consumption goods & $\begin{array}{l}112 \\
122 \\
51 \\
522 \\
61 \\
62 \\
63\end{array}$ & $\begin{array}{l}\text { Food \& bev., primary, mainly for household consumption } \\
\text { Food \& bev., primary, processed, for house. consumption } \\
\text { Passenger motor cars } \\
\text { Other non-industrial transport equipment } \\
\text { Durable consumer goods n.e.s. } \\
\text { Semi-durable consumer goods n.e.s. } \\
\text { Non-durable consumer goods n.e.s. }\end{array}$ \\
\hline
\end{tabular}

\section{B Statistical Appendices}


Table 20: Decomposition of 1995-2003 Market Share Growth with intra-EU Trade, (in \%)

\begin{tabular}{|c|c|c|c|c|c|c|c|c|}
\hline & \multicolumn{4}{|c|}{ Volume } & \multicolumn{4}{|c|}{ Value } \\
\hline & $\begin{array}{l}\text { market } \\
\text { share } \\
\text { growth }\end{array}$ & $\begin{array}{l}\text { exports } \\
\text { perform. }\end{array}$ & $\begin{array}{l}\text { geo. } \\
\text { structure } \\
\text { effect }\end{array}$ & $\begin{array}{l}\text { sectoral } \\
\text { structure } \\
\text { effect }\end{array}$ & $\begin{array}{l}\text { market } \\
\text { share } \\
\text { growth }\end{array}$ & $\begin{array}{l}\text { exports } \\
\text { perform. }\end{array}$ & $\begin{array}{l}\text { geo. } \\
\text { structure } \\
\text { effect }\end{array}$ & $\begin{array}{l}\text { sectoral } \\
\text { structure } \\
\text { effect }\end{array}$ \\
\hline EU25 & -3.1 & -6.1 & -1.3 & 4.4 & 7.5 & 1.4 & 0.8 & 5.2 \\
\hline EU15 & -12.1 & -16.8 & -1.3 & 6.0 & -2.7 & -11.3 & 0.9 & 7.6 \\
\hline Austria & 9.4 & 7.7 & -0.9 & 2.7 & 11.7 & 7.2 & 0.8 & 3.7 \\
\hline Belgium \& Lux. & -13.4 & -12.2 & -4.3 & 3.2 & -7.9 & -7.9 & -3.8 & 3.8 \\
\hline Cyprus & 29.6 & 38.4 & -4.2 & -4.6 & 88.1 & 84.7 & -1.7 & 5.1 \\
\hline Czech Rep. & 22.4 & 25.4 & -0.1 & -2.9 & 58.5 & 64.1 & 1.5 & -7.1 \\
\hline Denmark & -21.3 & -20.8 & -6.6 & 6.2 & -13.3 & -14.7 & -3.7 & 5.1 \\
\hline Estonia & 62.9 & 71.6 & -5.0 & -3.8 & 63.5 & 72.9 & -1.8 & -7.6 \\
\hline Finland & -7.7 & -19.8 & -3.1 & 15.2 & -5.3 & -14.7 & -0.1 & 9.4 \\
\hline France & -15.7 & -21.8 & -0.5 & 6.6 & -9.2 & -19.9 & 1.7 & 9.0 \\
\hline Germany & -1.9 & -12.0 & 1.9 & 8.3 & 0.4 & -13.5 & 4.1 & 9.8 \\
\hline Greece & -36.4 & -22.0 & 3.3 & -17.7 & -25.6 & -14.0 & 3.8 & -15.4 \\
\hline Hungary & 76.4 & 83.8 & -2.5 & -5.0 & 91.4 & 96.4 & -1.2 & -3.9 \\
\hline Ireland & 7.9 & -7.5 & -5.1 & 20.6 & 66.7 & 33.4 & -2.6 & 35.9 \\
\hline Italy & -23.6 & -18.2 & -1.9 & -3.5 & -11.8 & -6.8 & -0.7 & -4.4 \\
\hline Latvia & -5.4 & 18.4 & -3.0 & -20.7 & 4.4 & 30.6 & -0.2 & -25.9 \\
\hline Lithuania & 29.9 & 56.3 & -6.2 & -20.2 & 40.3 & 68.6 & -3.3 & -25.0 \\
\hline Malta & -53.8 & -72.2 & -1.9 & 20.3 & -40.7 & -55.5 & -1.5 & 16.3 \\
\hline Netherlands & -16.6 & -12.9 & -3.8 & 0.1 & -7.7 & -8.2 & -1.0 & 1.5 \\
\hline Poland & 54.1 & 66.0 & -5.0 & -6.9 & 61.9 & 77.2 & -3.4 & -12.0 \\
\hline Portugal & -11.6 & -2.2 & -0.7 & -8.7 & 3.0 & 8.8 & 1.1 & -6.9 \\
\hline Slovakia & 61.8 & 57.2 & 4.9 & -0.4 & 75.8 & 73.5 & 7.9 & -5.6 \\
\hline Slovenia & 0.7 & -9.5 & 3.6 & 6.6 & 8.7 & 1.2 & 4.1 & 3.3 \\
\hline Spain & 7.8 & 13.5 & -4.1 & -1.6 & 16.9 & 20.8 & -3.8 & -0.2 \\
\hline Sweden & -24.6 & -34.5 & -2.5 & 12.4 & -12.0 & -23.8 & -0.5 & 12.3 \\
\hline$U K$ & -33.4 & -38.8 & -4.9 & 10.4 & -14.6 & -27.7 & -0.4 & 13.5 \\
\hline USA & -3.0 & -39.4 & 27.8 & 8.6 & -13.5 & -33.1 & 7.7 & 12.0 \\
\hline Japan & -35.2 & -38.5 & -5.2 & 8.5 & -31.5 & -39.2 & 0.1 & 8.6 \\
\hline China & 63.1 & 113.1 & -21.0 & -28.9 & 66.0 & 114.1 & -16.4 & -31.4 \\
\hline Brazil & 13.4 & 42.2 & -10.4 & -18.4 & 6.9 & 43.1 & -11.8 & -24.4 \\
\hline Russia & -49.6 & -29.6 & 6.3 & -26.3 & -41.7 & -20.8 & 12.6 & -33.5 \\
\hline India & 25.2 & 58.1 & -2.1 & -30.9 & 19.2 & 54.1 & 0.1 & -34.2 \\
\hline
\end{tabular}


Decomposition of 1995-2003 Market Share Growth by Main Markets

Table 21: Decomposition of market share growth on the US market, (in \%)

\begin{tabular}{|c|c|c|c|c|c|c|}
\hline & \multicolumn{3}{|c|}{ Volume } & \multicolumn{3}{|c|}{ Value } \\
\hline & $\begin{array}{l}\text { market } \\
\text { share } \\
\text { growth }\end{array}$ & $\begin{array}{l}\text { exports } \\
\text { perform. }\end{array}$ & $\begin{array}{l}\text { sectoral } \\
\text { structure } \\
\text { effect }\end{array}$ & $\begin{array}{l}\text { market } \\
\text { share } \\
\text { growth }\end{array}$ & $\begin{array}{l}\text { exports } \\
\text { perform. }\end{array}$ & $\begin{array}{l}\text { sectoral } \\
\text { structure } \\
\text { effect }\end{array}$ \\
\hline EU25 & -7.5 & -28.6 & 21.1 & 12.1 & -11.0 & 23.1 \\
\hline EU15 & -9.8 & -31.6 & 21.8 & 9.3 & -15.0 & 24.3 \\
\hline Austria & 53.3 & 32.8 & 20.5 & 55.1 & 35.0 & 20.1 \\
\hline Belgium \& Lux. & -9.4 & -26.1 & 16.6 & 9.4 & -20.3 & 29.8 \\
\hline Cyprus & -107.6 & -67.1 & -40.5 & -86.1 & -31.6 & -54.5 \\
\hline Czech Rep. & 55.5 & 79.8 & -24.3 & 149.6 & 172.8 & -23.3 \\
\hline Denmark & -12.6 & -46.0 & 33.4 & 1.5 & -30.4 & 31.9 \\
\hline Estonia & -37.6 & -10.0 & -27.6 & -3.6 & 18.3 & -21.9 \\
\hline Finland & -18.6 & -57.9 & 39.2 & 4.4 & -37.9 & 42.3 \\
\hline France & -25.7 & -45.1 & 19.4 & -5.6 & -29.0 & 23.4 \\
\hline Germany & 0.1 & -19.4 & 19.5 & 11.8 & -13.7 & 25.5 \\
\hline Greece & -30.2 & -11.5 & -18.7 & 29.5 & 48.6 & -19.0 \\
\hline Hungary & 45.7 & 63.6 & -17.9 & 83.8 & 122.0 & -38.2 \\
\hline Ireland & 21.3 & -43.3 & 64.6 & 114.7 & 24.7 & 90.0 \\
\hline Italy & -27.2 & -31.0 & 3.9 & -9.0 & -2.6 & -6.4 \\
\hline Latvia & -10.4 & -43.9 & 33.5 & 8.3 & 1.5 & 6.8 \\
\hline Lithuania & 146.9 & 144.4 & 2.5 & 158.8 & 158.2 & 0.6 \\
\hline Malta & 21.0 & -20.0 & 41.0 & 87.6 & 111.5 & -23.9 \\
\hline Netherlands & -22.8 & -10.9 & -11.9 & 8.4 & 1.1 & 7.2 \\
\hline Poland & -16.8 & 2.5 & -19.3 & -6.4 & 22.1 & -28.5 \\
\hline Portugal & -41.6 & -31.1 & -10.5 & -6.9 & 15.9 & -22.8 \\
\hline Slovakia & 506.3 & 516.5 & -10.2 & 542.9 & 588.6 & -45.7 \\
\hline Slovenia & -26.2 & -47.8 & 21.7 & 4.5 & -11.1 & 15.6 \\
\hline Spain & -8.9 & -5.8 & -3.1 & 5.3 & 16.5 & -11.2 \\
\hline Sweden & -42.0 & -70.0 & 27.9 & -4.0 & -28.7 & 24.7 \\
\hline$U K$ & -18.0 & -46.0 & 28.1 & -4.5 & -29.5 & 25.0 \\
\hline Japan & -69.5 & -76.1 & 6.5 & -52.6 & -61.3 & 8.6 \\
\hline China & 49.2 & 99.0 & -49.9 & 66.5 & 123.5 & -57.0 \\
\hline Brazil & 11.7 & 27.8 & -16.0 & 19.6 & 41.9 & -22.3 \\
\hline Russia & -82.0 & -54.5 & -27.5 & -119.6 & -77.5 & -42.1 \\
\hline India & 19.8 & 69.1 & -49.3 & 25.1 & 75.7 & -50.5 \\
\hline
\end{tabular}


Table 22: Decomposition of market share growth on the Chinese market, (in \%)

\begin{tabular}{|c|c|c|c|c|c|c|}
\hline & \multicolumn{3}{|c|}{ Volume } & \multicolumn{3}{|c|}{ Value } \\
\hline & $\begin{array}{l}\text { market } \\
\text { share } \\
\text { growth }\end{array}$ & $\begin{array}{l}\text { exports } \\
\text { perform. }\end{array}$ & $\begin{array}{l}\text { sectoral } \\
\text { structure } \\
\text { effect }\end{array}$ & $\begin{array}{l}\text { market } \\
\text { share } \\
\text { growth }\end{array}$ & $\begin{array}{l}\text { exports } \\
\text { perform. }\end{array}$ & $\begin{array}{l}\text { sectoral } \\
\text { structure } \\
\text { effect }\end{array}$ \\
\hline EU25 & -11.3 & -20.2 & 8.9 & -11.0 & -23.2 & 12.1 \\
\hline EU15 & -11.7 & -20.4 & 8.7 & -11.9 & -23.9 & 12.0 \\
\hline Austria & -30.6 & -21.2 & -9.5 & -55.2 & -41.0 & -14.2 \\
\hline Belgium \& Lux. & -11.0 & -37.7 & 26.7 & -15.4 & -33.7 & 18.2 \\
\hline Cyprus & 29.0 & -12.0 & 41.0 & 64.7 & -8.0 & 72.7 \\
\hline Czech Rep. & -36.6 & -73.7 & 37.1 & -51.0 & -72.2 & 21.2 \\
\hline Denmark & -9.2 & -18.1 & 8.9 & 32.1 & 43.8 & -11.6 \\
\hline Estonia & 445.7 & 379.1 & 66.6 & 419.5 & 293.3 & 126.2 \\
\hline Finland & -1.8 & -6.2 & 4.5 & -4.9 & -26.6 & 21.8 \\
\hline France & -72.1 & -88.1 & 16.1 & -51.1 & -85.5 & 34.4 \\
\hline Germany & 31.3 & 21.3 & 10.0 & 20.3 & 7.3 & 13.0 \\
\hline Greece & 47.4 & -1.9 & 49.3 & 0.8 & 12.9 & -12.1 \\
\hline Hungary & -19.3 & -44.1 & 24.8 & 49.1 & -3.2 & 52.3 \\
\hline Ireland & -62.2 & -97.1 & 34.9 & 43.0 & 1.9 & 41.1 \\
\hline Italy & -23.4 & -11.8 & -11.5 & -42.2 & -8.9 & -33.3 \\
\hline Latvia & -347.0 & -165.3 & -181.7 & -271.3 & -90.1 & -181.2 \\
\hline Lithuania & 25.2 & 114.5 & -89.3 & 74.6 & 152.5 & -77.9 \\
\hline Malta & 388.8 & 626.1 & -237.3 & 363.8 & 403.6 & -39.8 \\
\hline Netherlands & -14.3 & -20.0 & 5.6 & -18.6 & -29.3 & 10.7 \\
\hline Poland & 17.2 & -50.4 & 67.6 & 14.6 & -18.3 & 33.0 \\
\hline Portugal & -81.2 & -75.7 & -5.5 & -144.8 & -143.7 & -1.1 \\
\hline Slovakia & -375.3 & -419.1 & 43.8 & -199.3 & -218.9 & 19.6 \\
\hline Slovenia & 152.2 & 238.9 & -86.7 & 174.1 & 271.4 & -97.3 \\
\hline Spain & -72.4 & -65.1 & -7.3 & -123.3 & -116.3 & -7.0 \\
\hline Sweden & -55.9 & -44.3 & -11.6 & -32.3 & -54.9 & 22.6 \\
\hline$U K$ & -35.6 & -46.6 & 10.9 & -28.2 & -47.9 & 19.7 \\
\hline USA & -16.3 & -26.6 & 10.3 & -21.1 & -40.6 & 19.5 \\
\hline Japan & 1.0 & -24.8 & 25.8 & -11.4 & -39.8 & 28.5 \\
\hline Brazil & 79.8 & 50.6 & 29.2 & 33.0 & 15.9 & 17.1 \\
\hline Russia & -101.4 & 19.5 & -120.9 & -71.2 & 51.8 & -123.0 \\
\hline India & 157.3 & 147.1 & 10.2 & 132.1 & 137.5 & -5.4 \\
\hline
\end{tabular}


Table 23: Decomposition of market share growth in the Japanese market, (in \%)

\begin{tabular}{|c|c|c|c|c|c|c|}
\hline & \multicolumn{3}{|c|}{ Volume } & \multicolumn{3}{|c|}{ Value } \\
\hline & $\begin{array}{l}\text { market } \\
\text { share } \\
\text { growth }\end{array}$ & $\begin{array}{l}\text { exports } \\
\text { perform. }\end{array}$ & $\begin{array}{l}\text { sectoral } \\
\text { structure } \\
\text { effect }\end{array}$ & $\begin{array}{l}\text { market } \\
\text { share } \\
\text { growth }\end{array}$ & $\begin{array}{l}\text { exports } \\
\text { perform. }\end{array}$ & $\begin{array}{l}\text { sectoral } \\
\text { structure } \\
\text { effect }\end{array}$ \\
\hline EU25 & -4 & -19 & 18 & -8 & -26 & 23 \\
\hline EU15 & -3 & -18 & 18 & -8 & -26 & 23 \\
\hline Austria & 18 & 28 & -6 & -9 & 3 & -12 \\
\hline Belgium \& Lux. & 8 & -24 & 30 & 8 & -19 & 32 \\
\hline Cyprus & 11 & 73 & -60 & -11 & 78 & -87 \\
\hline Czech Rep. & -28 & -12 & -9 & 7 & 1 & 12 \\
\hline Denmark & 19 & -9 & 44 & 5 & 0 & 16 \\
\hline Estonia & 109 & 186 & -69 & -25 & 54 & -72 \\
\hline Finland & 10 & 6 & 8 & -25 & -19 & -6 \\
\hline France & -6 & -29 & 25 & -4 & -24 & 23 \\
\hline Germany & 8 & -8 & 23 & -11 & -32 & 27 \\
\hline Greece & -63 & -22 & -48 & -62 & -17 & -57 \\
\hline Hungary & -39 & -44 & 15 & 77 & 59 & 24 \\
\hline Ireland & 1 & -43 & 56 & 64 & 17 & 71 \\
\hline Italy & -22 & -14 & -13 & -18 & -8 & -14 \\
\hline Latvia & 247 & 242 & 7 & 258 & 262 & 2 \\
\hline Lithuania & 39 & 139 & -100 & 30 & 142 & -116 \\
\hline Malta & -43 & -117 & 77 & -85 & -166 & 74 \\
\hline Netherlands & 10 & -29 & 41 & -9 & -37 & 34 \\
\hline Poland & 50 & .79 & -33 & 46 & 69 & -32 \\
\hline Portugal & -46 & -33 & -15 & -63 & -45 & -25 \\
\hline Slovakia & -109 & -142 & 38 & -109 & -139 & 45 \\
\hline Slovenia & -32 & 9 & -34 & -66 & -31 & -35 \\
\hline Spain & -51 & -50 & -02 & -42 & -39 & -6 \\
\hline Sweden & 11 & 7 & 1 & -30 & -53 & 21 \\
\hline$U K$ & -24 & -34 & 9 & -16 & -42 & 31 \\
\hline USA & -57 & -81 & 29 & -23 & -60 & 46 \\
\hline China & 69 & 107 & -49 & 58 & 99 & -54 \\
\hline Brazil & -13 & 4 & -21 & -44 & -4 & -42 \\
\hline Russia & -15 & 32 & -42 & -28 & 37 & -65 \\
\hline India & -25 & 38 & -68 & -34 & 32 & -70 \\
\hline
\end{tabular}


Table 24: Decomposition of market share growth in the Indian market, (in \%)

\begin{tabular}{|c|c|c|c|c|c|c|}
\hline & \multicolumn{3}{|c|}{ Volume } & \multicolumn{3}{|c|}{ Value } \\
\hline & $\begin{array}{l}\text { market } \\
\text { share } \\
\text { growth }\end{array}$ & $\begin{array}{l}\text { exports } \\
\text { perform. }\end{array}$ & $\begin{array}{l}\text { sectoral } \\
\text { structure } \\
\text { effect }\end{array}$ & $\begin{array}{l}\text { market } \\
\text { share } \\
\text { growth }\end{array}$ & $\begin{array}{l}\text { exports } \\
\text { perform. }\end{array}$ & $\begin{array}{l}\text { sectoral } \\
\text { structure } \\
\text { effect }\end{array}$ \\
\hline EU25 & -68 & -60 & -8 & -49 & -43 & -6 \\
\hline EU15 & -68 & -58 & -10 & -50 & -42 & -8 \\
\hline Austria & -21 & -24 & 3 & -12 & -17 & 5 \\
\hline Belgium \& Lux. & -43 & -39 & -5 & -21 & -20 & -1 \\
\hline Cурrus & -81 & -105 & 25 & -57 & -98 & 41 \\
\hline Czech Rep. & -33 & -93 & 61 & 2 & -63 & 65 \\
\hline Denmark & -106 & -119 & 14 & -120 & -98 & -22 \\
\hline Estonia & 106 & 39 & 68 & 98 & 85 & 14 \\
\hline Finland & -22 & 1 & -23 & 6 & 43 & -37 \\
\hline France & -60 & -64 & 4 & -45 & -50 & 5 \\
\hline Germany & -75 & -58 & -17 & -60 & -47 & -14 \\
\hline Greece & 180 & 204 & -24 & 227 & 211 & 16 \\
\hline Hungary & -104 & -112 & 8 & -73 & -76 & 3 \\
\hline Ireland & -14 & -80 & 67 & 121 & 21 & 100 \\
\hline Italy & -81 & -42 & -39 & -66 & -32 & -33 \\
\hline Latvia & -238 & -200 & -38 & -172 & -183 & 11 \\
\hline Lithuania & -316 & -208 & -108 & -496 & -351 & -145 \\
\hline Malta & 54 & -13 & 67 & 84 & 63 & 22 \\
\hline Netherlands & -35 & -73 & 38 & -28 & -32 & 4 \\
\hline Poland & -66 & -169 & 102 & 29 & -116 & 146 \\
\hline Portugal & 46 & 51 & -5 & 33 & 47 & -14 \\
\hline Slovakia & -180 & -204 & 23 & -198 & -242 & 44 \\
\hline Slovenia & -71 & -96 & 25 & -57 & -71 & 14 \\
\hline Spain & -16 & -2 & -14 & -20 & 2 & -22 \\
\hline Sweden & 10 & -51 & 61 & 44 & 15 & 29 \\
\hline$U K$ & -85 & -68 & -17 & -62 & -62 & 0 \\
\hline USA & -2 & 4 & -5 & -29 & -27 & -3 \\
\hline Japan & -1 & 2 & -3 & -68 & -57 & -12 \\
\hline China & -1 & -7 & 6 & 108 & 125 & -17 \\
\hline Brazil & -36 & -12 & -24 & 5 & 22 & -17 \\
\hline Russia & 7 & 2 & 5 & -35 & -13 & -22 \\
\hline
\end{tabular}


Table 25: Decomposition of market share growth in the Brazilian market, (in \%)

\begin{tabular}{|c|c|c|c|c|c|c|}
\hline & \multicolumn{3}{|c|}{ Volume } & \multicolumn{3}{|c|}{ Value } \\
\hline & $\begin{array}{l}\text { market } \\
\text { share } \\
\text { growth }\end{array}$ & $\begin{array}{l}\text { exports } \\
\text { perform. }\end{array}$ & $\begin{array}{l}\text { sectoral } \\
\text { structure } \\
\text { effect }\end{array}$ & $\begin{array}{l}\text { market } \\
\text { share } \\
\text { growth }\end{array}$ & $\begin{array}{l}\text { exports } \\
\text { perform. }\end{array}$ & $\begin{array}{l}\text { sectoral } \\
\text { structure } \\
\text { effect }\end{array}$ \\
\hline EU25 & -3 & -2 & 18 & -5 & -3 & 17 \\
\hline EU15 & -3 & -2 & 17 & -6 & -3 & 17 \\
\hline Austria & -37 & -55 & 48 & -49 & -79 & 42 \\
\hline Belgium \& Lux. & 26 & -2 & 14 & 30 & 6 & 13 \\
\hline Cyprus & 42 & 165 & -141 & -60 & 61 & -144 \\
\hline Czech Rep. & -22 & 2 & -34 & -10 & 15 & -34 \\
\hline Denmark & -35 & -36 & 16 & -32 & -37 & 8 \\
\hline Estonia & 524 & 289 & 224 & 501 & 247 & 274 \\
\hline Finland & -56 & -81 & 24 & -54 & -71 & 15 \\
\hline France & 36 & 35 & 24 & 25 & 33 & 35 \\
\hline Germany & -7 & -5 & 15 & -4 & 1 & 11 \\
\hline Greece & -141 & -146 & -97 & -129 & -112 & -103 \\
\hline Hungary & 35 & 48 & 1 & 76 & 87 & 19 \\
\hline Ireland & -33 & -60 & 53 & -15 & -54 & 58 \\
\hline Italy & -33 & -14 & -1 & -40 & -24 & -3 \\
\hline Latvia & 92 & 183 & -87 & 105 & 187 & -76 \\
\hline Lithuania & -66 & 97 & -184 & -43 & 129 & -170 \\
\hline Malta & -263 & -241 & -35 & 32 & 85 & -66 \\
\hline Netherlands & -14 & -6 & 12 & -5 & -1 & 27 \\
\hline Poland & 158 & 26 & 137 & 170 & 66 & 121 \\
\hline Portugal & -16 & 18 & -27 & -14 & 21 & -28 \\
\hline Slovakia & 48 & -11 & 71 & 49 & 1 & 74 \\
\hline Slovenia & -60 & -115 & 81 & -56 & -100 & 77 \\
\hline Spain & -19 & 0 & -31 & -19 & 1 & -26 \\
\hline Sweden & -21 & -23 & 55 & -21 & -32 & 63 \\
\hline$U K$ & 39 & 2 & 68 & 22 & -9 & 56 \\
\hline USA & -21 & -40 & 58 & -13 & -32 & 58 \\
\hline Japan & -16 & -23 & 13 & -5 & -3 & 5 \\
\hline China & 58 & 109 & -90 & 60 & 104 & -89 \\
\hline Russia & 61 & -1 & 99 & 71 & -9 & 106 \\
\hline India & 52 & 104 & -76 & 46 & 93 & -82 \\
\hline
\end{tabular}


Table 26: Decomposition of market share growth in the Russian market, (in \%)

\begin{tabular}{|c|c|c|c|c|c|c|}
\hline & \multicolumn{3}{|c|}{ Volume } & \multicolumn{3}{|c|}{ Value } \\
\hline & $\begin{array}{l}\text { market } \\
\text { share } \\
\text { growth }\end{array}$ & $\begin{array}{l}\text { exports } \\
\text { perform. }\end{array}$ & $\begin{array}{l}\text { sectoral } \\
\text { structure } \\
\text { effect }\end{array}$ & $\begin{array}{l}\text { market } \\
\text { share } \\
\text { growth }\end{array}$ & $\begin{array}{l}\text { exports } \\
\text { perform. }\end{array}$ & $\begin{array}{l}\text { sectoral } \\
\text { structure } \\
\text { effect }\end{array}$ \\
\hline EU25 & 23 & 16 & 18 & 12 & 7 & 12 \\
\hline EU15 & 29 & 18 & 21 & 18 & 9 & 15 \\
\hline Austria & 23 & 30 & 18 & -22 & -5 & 7 \\
\hline Belgium \& Lux. & -27 & -15 & -10 & -49 & -28 & -22 \\
\hline Cyprus & -179 & -106 & -61 & -316 & -232 & -79 \\
\hline Czech Rep. & -58 & -54 & 20 & -43 & -33 & 13 \\
\hline Denmark & -12 & -22 & 23 & -34 & -28 & 17 \\
\hline Estonia & 104 & 25 & 62 & 112 & 69 & 45 \\
\hline Finland & 70 & 34 & 56 & 51 & 22 & 46 \\
\hline France & 33 & 25 & 21 & 26 & 27 & 11 \\
\hline Germany & 44 & 33 & 19 & 31 & 17 & 13 \\
\hline Greece & 37 & 30 & -16 & -71 & -90 & -6 \\
\hline Hungary & -48 & -31 & -4 & -60 & -35 & -6 \\
\hline Ireland & 4 & -94 & 111 & 20 & -70 & 119 \\
\hline Italy & -11 & -4 & -2 & -16 & -10 & -4 \\
\hline Latvia & -68 & -65 & 10 & -98 & -76 & 3 \\
\hline Lithuania & -12 & 6 & 2 & -59 & -39 & -2 \\
\hline Malta & -96 & -53 & -23 & 91 & 180 & -106 \\
\hline Netherlands & 10 & 0 & 13 & 13 & 11 & 6 \\
\hline Poland & 30 & 42 & -9 & 4 & 29 & -17 \\
\hline Portugal & -18 & 2 & 4 & -18 & -5 & 14 \\
\hline Slovakia & 27 & 56 & -22 & 14 & 50 & -28 \\
\hline Slovenia & -28 & -18 & 20 & -29 & -24 & 28 \\
\hline Spain & 74 & 69 & 6 & 71 & 71 & 1 \\
\hline Sweden & 37 & 17 & 49 & 39 & 5 & 58 \\
\hline$U K$ & 25 & 14 & 19 & 34 & 19 & 18 \\
\hline USA & 19 & 15 & 4 & 16 & -32 & 56 \\
\hline Japan & 27 & 77 & -15 & 1 & 36 & -14 \\
\hline China & -22 & 12 & -40 & 49 & 63 & -27 \\
\hline Brazil & 175 & 99 & -14 & 82 & 82 & -64 \\
\hline India & 50 & -23 & 52 & -9 & -21 & 0 \\
\hline
\end{tabular}


Table 27: Market Shares by production stage in 2003 and change over the 1995-2003 period, (in \% and p.p.)

\begin{tabular}{|c|c|c|c|c|c|c|c|c|c|c|}
\hline & \multicolumn{2}{|c|}{ Consumption } & \multicolumn{2}{|c|}{ Capital } & \multicolumn{2}{|c|}{ Primary } & \multicolumn{2}{|c|}{$\begin{array}{c}\text { Parts and } \\
\text { components }\end{array}$} & \multicolumn{2}{|c|}{ Transformed } \\
\hline & 2003 & $\Delta$ & 2003 & $\Delta$ & 2003 & $\Delta$ & 2003 & $\Delta$ & 2003 & $\Delta$ \\
\hline EU25 & 26.1 & 2.1 & 30.8 & 4.9 & 14.1 & 3.7 & 27.6 & 3.5 & 26.7 & 1.5 \\
\hline France & 3.1 & 0.0 & 3.8 & 0.2 & 1.8 & 0.6 & 2.9 & -0.5 & 2.3 & -0.2 \\
\hline Germany & 6.6 & 0.6 & 10.5 & 1.5 & 2.5 & 0.6 & 8.7 & 0.9 & 6.7 & -0.1 \\
\hline Italy & 3.2 & -0.2 & 3.9 & 0.6 & 0.6 & 0.1 & 2.6 & -0.2 & 3.1 & 0.1 \\
\hline Poland & 1.4 & 0.4 & 0.8 & 0.5 & 1.0 & 0.5 & 1.3 & 1.0 & 1.3 & 0.4 \\
\hline Spain & 1.1 & 0.2 & 0.7 & 0.0 & 0.4 & 0.2 & 0.8 & 0.3 & 1.0 & 0.1 \\
\hline UK & 2.8 & 0.1 & 2.4 & -0.9 & 1.4 & 0.6 & 3.1 & -0.4 & 2.1 & -0.5 \\
\hline Japan & 8.7 & -1.2 & 13.1 & -9.8 & 1.4 & 0.9 & 15.7 & -10.3 & 7.4 & -2.5 \\
\hline Korea & 2.8 & -0.7 & 6.4 & 2.8 & 0.5 & 0.0 & 4.2 & -2.2 & 3.7 & -0.4 \\
\hline Russia & 0.4 & 0.0 & 0.6 & 0.6 & 3.6 & 1.2 & 0.4 & 0.3 & 2.8 & 0.4 \\
\hline India & 1.7 & 0.2 & 0.3 & 0.1 & 1.3 & 0.5 & 0.4 & 0.1 & 1.5 & 0.5 \\
\hline Ukraine & 0.2 & 0.1 & 0.1 & 0.1 & 0.8 & 0.5 & 0.1 & 0.1 & 0.6 & 0.3 \\
\hline USA & 8.8 & -2.0 & 15.7 & -3.9 & 26.8 & -4.1 & 16.2 & -2.8 & 13.7 & -1.4 \\
\hline Chinese world & 19.5 & 2.2 & 13.1 & 5.3 & 5.4 & 1.8 & 14.6 & 8.1 & 11.8 & 2.3 \\
\hline China & 16.6 & 3.9 & 9.2 & 5.9 & 4.4 & 1.5 & 9.6 & 7.1 & 7.5 & 2.8 \\
\hline Hong Kong & 1.9 & -0.4 & 1.0 & 0.2 & 0.7 & 0.4 & 1.6 & 0.5 & 1.4 & 0.5 \\
\hline Mediterranean & 2.9 & 0.3 & 0.7 & 0.5 & 1.2 & 0.2 & 0.6 & 0.3 & 1.5 & 0.2 \\
\hline GCC & 0.3 & 0.0 & 0.3 & 0.2 & 0.5 & 0.0 & 0.3 & 0.1 & 1.1 & 0.2 \\
\hline Mercosur & 1.8 & -0.3 & 1.3 & 0.5 & 10.6 & 4.0 & 1.0 & -0.1 & 3.2 & -0.2 \\
\hline Brazil & 1.2 & 0.0 & 1.1 & 0.5 & 6.1 & 2.6 & 0.9 & 0.0 & 2.1 & -0.3 \\
\hline ASEAN & 6.2 & -2.4 & 4.4 & -4.9 & 7.8 & -3.1 & 8.0 & 0.1 & 6.1 & 0.1 \\
\hline RoW & 20.5 & 1.7 & 13.2 & 3.5 & 26.2 & -5.3 & 10.9 & 2.7 & 19.9 & -1.6 \\
\hline All & 100 & 0 & 100 & 0 & 100 & 0 & 100 & 0 & 100 & 0 \\
\hline
\end{tabular}


Table 28: Decomposition of Market Share Growth, Exports Performance, and the sectoral structure effect by products, 1995-2003 (\%)

Decomposition of Market Share Growth by products, 1995-2003 (\%)

\begin{tabular}{|c|c|c|c|c|c|c|c|c|}
\hline & EU25 & EU15 & Brazil & China & Japan & Russia & India & USA \\
\hline & \multicolumn{8}{|c|}{ Volume } \\
\hline Agriculture, hunting & -1.1 & -0.6 & 6.6 & 0.6 & 0.0 & -0.7 & 1.3 & -2.7 \\
\hline Forestry, logging & -0.2 & 0.0 & -0.2 & 0.0 & 0.0 & 1.4 & -0.3 & -0.3 \\
\hline Fishing, fish farming & -0.1 & -0.1 & 0.0 & 0.0 & 0.0 & -2.5 & 0.0 & -0.1 \\
\hline Food products $\&$ beverages & -4.4 & -2.5 & 3.8 & 0.6 & 0.4 & -6.3 & -5.5 & -1.3 \\
\hline Tobacco products & -0.5 & -0.3 & -1.9 & -0.6 & 0.0 & 0.1 & 0.0 & -2.2 \\
\hline Textiles & -1.7 & -1.0 & -0.3 & 4.5 & -0.4 & -0.1 & 5.3 & 0.1 \\
\hline Wearing apparel & -1.4 & -0.7 & -0.2 & 2.4 & -0.1 & 0.2 & -0.8 & -0.6 \\
\hline Leather & -1.7 & -0.9 & -0.5 & 1.8 & -0.1 & -0.1 & 1.2 & 0.0 \\
\hline Wood \& of products & 1.5 & 0.2 & 1.1 & 0.5 & 0.0 & 0.1 & 0.1 & -0.5 \\
\hline Pulp, paper \& paper products & 0.4 & 0.0 & 0.5 & 0.3 & -0.1 & -0.1 & 0.4 & -0.9 \\
\hline Publishing, printing \& reproduction of rec. media & -0.4 & -0.3 & 0.0 & 0.6 & -0.2 & 0.3 & -0.1 & -1.3 \\
\hline Chemicals \& chemical products & 1.0 & 0.4 & 0.4 & 2.8 & -2.4 & -7.7 & 9.9 & -2.4 \\
\hline Rubber \& plastic & 1.0 & 0.3 & 0.3 & 2.8 & -0.1 & -0.1 & 0.7 & 3.4 \\
\hline Non-metallic mineral products & -0.5 & -0.5 & 0.1 & 1.1 & -0.4 & -0.4 & 0.6 & -0.2 \\
\hline Basic metals & -4.3 & -2.1 & -3.0 & -1.3 & -0.5 & -19.0 & 5.2 & -1.6 \\
\hline Metal products & -0.6 & -0.8 & -0.4 & 2.7 & -0.8 & -0.6 & 1.4 & -0.5 \\
\hline Machinery & -9.4 & -5.9 & -0.7 & 7.0 & -5.7 & -5.5 & 1.7 & -1.0 \\
\hline Office machinery \& computers & -0.5 & -0.4 & 0.0 & 15.4 & -2.4 & -0.2 & 0.7 & -2.4 \\
\hline Electrical machinery & -0.7 & -0.9 & -0.3 & 5.5 & -2.3 & -0.8 & 1.3 & 5.4 \\
\hline Radio, TV \& communication equipment & 0.2 & -1.8 & 1.4 & 11.4 & -14.4 & -0.1 & 0.0 & 6.8 \\
\hline Medical, precision \& optical instruments & -0.4 & -0.3 & -0.1 & 1.0 & -0.5 & 0.3 & 0.4 & 0.8 \\
\hline Motor vehicles, trailers \& semi-trailers & 9.8 & 2.9 & 5.6 & 0.7 & -3.3 & -3.7 & 1.0 & -0.4 \\
\hline Other transport equipment & -1.2 & -1.0 & 0.7 & 1.2 & -0.4 & -4.6 & -0.2 & -1.3 \\
\hline \multirow[t]{2}{*}{ Furniture; manufacturing n.e.c. } & -0.1 & -0.6 & 0.4 & 2.0 & -1.5 & 0.1 & 0.9 & 0.3 \\
\hline & \multicolumn{8}{|c|}{ Value } \\
\hline Agriculture, hunting & 0.2 & -0.3 & 2.7 & 0.7 & 0.0 & 0.0 & -0.6 & -2.2 \\
\hline Forestry, logging & 0.1 & 0.0 & -0.2 & 0.0 & 0.0 & 0.7 & 0.0 & -0.3 \\
\hline Fishing, fish farming & 0.0 & -0.1 & 0.0 & -0.1 & 0.0 & -2.4 & 0.0 & -0.1 \\
\hline Food products $\&$ beverages & 1.1 & -2.5 & 0.6 & 0.1 & 0.6 & -5.2 & -4.9 & -1.1 \\
\hline Tobacco products & 0.1 & -0.2 & -1.7 & -0.4 & -0.1 & 0.1 & 0.0 & -0.5 \\
\hline Textiles & 0.3 & -0.8 & -0.6 & 2.4 & -0.7 & -0.4 & 0.6 & 0.0 \\
\hline Wearing apparel & 0.1 & -0.4 & -0.2 & 2.8 & -0.1 & 0.0 & 1.0 & -0.5 \\
\hline Leather & 0.3 & -0.6 & -0.9 & 1.4 & -0.1 & 0.0 & 1.1 & -0.1 \\
\hline Wood \& of products & -0.3 & 0.1 & 1.0 & 0.5 & 0.0 & 0.6 & 0.0 & -0.5 \\
\hline Pulp, paper \& paper products & 0.0 & -0.3 & -1.3 & 0.4 & -0.1 & -1.2 & 0.4 & -1.2 \\
\hline Publishing, printing \& reproduction of rec. media & 0.0 & -0.1 & 0.0 & 0.5 & -0.1 & -0.3 & 0.4 & -0.5 \\
\hline Chemicals \& chemical products & -1.7 & 4.0 & 0.2 & 1.8 & -1.6 & -7.9 & 8.7 & 1.0 \\
\hline Rubber \& plastic & -0.3 & 0.3 & 0.1 & 2.5 & -0.1 & -0.1 & 0.5 & 0.1 \\
\hline Non-metallic mineral products & 0.1 & -0.5 & 0.1 & 0.9 & -0.4 & -0.1 & 0.5 & -0.1 \\
\hline Basic metals & 1.0 & -2.1 & -3.4 & -1.0 & -0.8 & -20.9 & 5.8 & -1.6 \\
\hline Metal products & 0.0 & -0.6 & -0.3 & 2.8 & -0.7 & 0.5 & 1.4 & -0.4 \\
\hline Machinery & 1.4 & -4.1 & -0.3 & 6.2 & -6.2 & -4.1 & 1.9 & -2.2 \\
\hline Office machinery \& computers & -0.2 & -0.2 & 0.0 & 16.0 & -5.2 & -0.2 & -0.5 & -2.9 \\
\hline Electrical machinery & -0.2 & -0.3 & -0.1 & 6.0 & -2.3 & -0.5 & 0.7 & -0.4 \\
\hline Radio, TV \& communication equipment & -0.9 & 0.0 & 2.2 & 12.0 & -9.7 & 0.0 & 0.1 & -0.1 \\
\hline Medical, precision \& optical instruments & -0.2 & 0.4 & 0.0 & 2.2 & -0.1 & 1.0 & 0.5 & 0.1 \\
\hline Motor vehicles, trailers \& semi-trailers & -2.7 & 3.7 & 5.0 & 0.7 & -1.8 & -1.5 & 1.0 & 0.1 \\
\hline Other transport equipment & -0.5 & 0.6 & 3.7 & 1.2 & -0.9 & -1.0 & -0.1 & 0.3 \\
\hline Furniture; manufacturing n.e.c. & -0.1 & -0.4 & 0.3 & 6.3 & -1.0 & 0.2 & 0.6 & -0.3 \\
\hline
\end{tabular}


Cheptea, Gaulier, Sondjo and Zignago (2006), Study Report

Decomposition of Exports Performance by products, 1995-2003 (\%)

\begin{tabular}{|c|c|c|c|c|c|c|c|c|}
\hline & EU25 & EU15 & Brazil & China & Japan & Russia & India & USA \\
\hline & \multicolumn{8}{|c|}{ Volume } \\
\hline Agriculture, hunting & -0.3 & -0.3 & 5.2 & 2.4 & 0.0 & -0.9 & 4.1 & -2.2 \\
\hline Forestry, logging & 0.0 & 0.0 & 0.1 & 0.1 & 0.0 & -1.0 & 0.4 & -0.1 \\
\hline Fishing, fish farming & 0.0 & 0.0 & 0.0 & 0.3 & 0.0 & -0.1 & 0.1 & -0.1 \\
\hline Food products \& beverages & -1.4 & -1.5 & 8.2 & 4.1 & -0.2 & -2.1 & 7.7 & -2.2 \\
\hline Tobacco products & -0.1 & -0.1 & 0.1 & 0.1 & 0.0 & 0.0 & 0.1 & -0.3 \\
\hline Textiles & -0.7 & -0.7 & 0.7 & 11.1 & -0.6 & -0.2 & 11.6 & -0.8 \\
\hline Wearing apparel & -0.1 & -0.3 & 0.1 & 13.8 & 0.0 & -0.2 & 9.0 & -0.3 \\
\hline Leather & -0.3 & -0.4 & 2.1 & 8.1 & 0.0 & -0.1 & 3.0 & -0.1 \\
\hline Wood \& of products & 0.0 & -0.2 & 1.3 & 1.3 & 0.0 & -0.8 & 0.1 & -0.3 \\
\hline Pulp, paper \& paper products & -0.3 & -0.5 & 2.0 & 0.5 & -0.3 & -1.0 & 0.3 & -1.2 \\
\hline $\begin{array}{l}\text { Publishing, printing \& reproduction of } \\
\text { recorded media }\end{array}$ & -0.3 & -0.3 & 0.1 & 0.6 & -0.1 & -0.1 & 0.2 & -0.7 \\
\hline Chemicals \& chemical products & -3.7 & -3.5 & 2.9 & 5.3 & -3.9 & -4.2 & 8.2 & -6.2 \\
\hline Rubber \& plastic & -0.5 & -0.6 & 0.8 & 3.7 & -1.0 & -0.2 & 1.3 & -1.3 \\
\hline Non-metallic mineral products & -0.4 & -0.4 & 0.7 & 1.8 & -0.5 & -0.2 & 1.0 & -0.4 \\
\hline Basic metals & -0.8 & -1.0 & 4.9 & 2.9 & -2.1 & -13.3 & 3.6 & -1.6 \\
\hline Metal products & -0.5 & -0.7 & 0.5 & 4.0 & -0.7 & -0.3 & 2.2 & -1.1 \\
\hline Machinery & -3.9 & -3.7 & 2.5 & 6.9 & -5.8 & -0.5 & 1.9 & -4.8 \\
\hline Office machinery \& computers & -0.7 & -0.7 & 0.3 & 10.4 & -3.7 & 0.0 & 0.4 & -2.8 \\
\hline Electrical machinery & -0.9 & -1.1 & 0.7 & 8.3 & -2.6 & -0.3 & 1.2 & -2.0 \\
\hline Radio, TV \& communication equipment & -1.7 & -1.6 & 1.4 & 12.5 & -5.8 & -0.1 & 0.4 & -3.5 \\
\hline Medical, precision \& optical instruments & -0.9 & -0.8 & 0.2 & 2.6 & -1.9 & -0.1 & 0.3 & -2.2 \\
\hline Motor vehicles, trailers \& semi-trailers & -1.7 & -2.6 & 4.6 & 0.8 & -9.1 & -0.6 & 1.3 & -4.0 \\
\hline Other transport equipment & -1.6 & -1.5 & 2.3 & 1.5 & -1.8 & -0.5 & 0.8 & -4.2 \\
\hline \multirow[t]{2}{*}{ Furniture; manufacturing n.e.c. } & -0.2 & -0.5 & 0.5 & 11.5 & -0.7 & -0.1 & 0.7 & -0.5 \\
\hline & \multicolumn{8}{|c|}{ Value } \\
\hline Agriculture, hunting & 0.0 & -0.2 & 5.0 & 2.4 & 0.0 & -0.7 & 3.9 & -1.9 \\
\hline Forestry, logging & 0.0 & 0.0 & 0.1 & 0.1 & 0.0 & -0.8 & 0.4 & -0.1 \\
\hline Fishing, fish farming & 0.0 & 0.0 & 0.0 & 0.3 & 0.0 & -0.1 & 0.1 & 0.0 \\
\hline Food products $\&$ beverages & -0.9 & -0.9 & 7.9 & 4.2 & -0.2 & -1.8 & 7.2 & -2.0 \\
\hline Tobacco products & -0.1 & -0.1 & 0.1 & 0.1 & 0.0 & 0.0 & 0.1 & -0.2 \\
\hline Textiles & -0.5 & -0.5 & 0.8 & 11.3 & -0.6 & -0.2 & 10.6 & -0.7 \\
\hline Wearing apparel & 0.2 & -0.2 & 0.1 & 14.1 & 0.0 & -0.2 & 8.2 & -0.3 \\
\hline Leather & 0.0 & -0.1 & 2.1 & 8.3 & 0.0 & -0.1 & 2.7 & -0.1 \\
\hline Wood \& of products & 0.1 & -0.1 & 1.2 & 1.3 & 0.0 & -0.7 & 0.1 & -0.3 \\
\hline Pulp, paper \& paper products & -0.2 & -0.3 & 2.0 & 0.6 & -0.3 & -0.9 & 0.2 & -1.1 \\
\hline $\begin{array}{l}\text { Publishing, printing \& reproduction of } \\
\text { recorded media }\end{array}$ & -0.2 & -0.2 & 0.1 & 0.6 & -0.1 & -0.1 & 0.2 & -0.6 \\
\hline Chemicals \& chemical products & -2.9 & -2.1 & 2.9 & 5.4 & -4.3 & -3.5 & 7.3 & -5.7 \\
\hline Rubber \& plastic & -0.1 & -0.4 & 0.8 & 3.8 & -1.1 & -0.2 & 1.2 & -1.2 \\
\hline Non-metallic mineral products & -0.1 & -0.2 & 0.7 & 1.8 & -0.5 & -0.1 & 0.9 & -0.4 \\
\hline Basic metals & -0.5 & -0.7 & 5.1 & 3.0 & -2.2 & -11.2 & 3.3 & -1.4 \\
\hline Metal products & -0.1 & -0.4 & 0.5 & 4.0 & -0.7 & -0.3 & 2.0 & -1.0 \\
\hline Machinery & -3.5 & -2.6 & 2.5 & 7.0 & -6.6 & -0.5 & 1.7 & -4.3 \\
\hline Office machinery \& computers & -0.1 & -0.3 & 0.3 & 10.5 & -3.8 & 0.0 & 0.4 & -2.3 \\
\hline Electrical machinery & -0.3 & -0.8 & 0.7 & 8.4 & -2.8 & -0.3 & 1.0 & -1.8 \\
\hline Radio, TV \& communication equipment & -1.2 & -1.1 & 1.3 & 12.5 & -5.9 & -0.1 & 0.4 & -3.0 \\
\hline Medical, precision \& optical instruments & -0.8 & -0.5 & 0.2 & 2.6 & -2.1 & -0.1 & 0.2 & -2.0 \\
\hline Motor vehicles, trailers \& semi-trailers & -0.3 & -1.8 & 4.3 & 0.8 & -9.8 & -0.6 & 1.2 & -3.7 \\
\hline Other transport equipment & -1.6 & -1.1 & 2.1 & 1.5 & -1.7 & -0.5 & 0.7 & -3.9 \\
\hline Furniture; manufacturing n.e.c. & 0.2 & -0.3 & 0.5 & 11.7 & -0.7 & -0.1 & 0.6 & -0.5 \\
\hline
\end{tabular}


European Positioning in the International Division of Labour

Decomposition of the Sectoral Structure Effect by products, 1995-2003 (\%)

\begin{tabular}{|c|c|c|c|c|c|c|c|c|}
\hline & EU25 & EU15 & Brazil & China & Japan & Russia & India & USA \\
\hline & \multicolumn{8}{|c|}{ Volume } \\
\hline Agriculture, hunting & -0.7 & -0.6 & -4.5 & -1.2 & 0.0 & -0.8 & -2.8 & -1.7 \\
\hline Forestry, logging & 0.0 & 0.0 & -0.1 & 0.0 & 0.0 & -0.7 & -0.6 & -0.1 \\
\hline Fishing, fish farming & -0.1 & -0.1 & 0.0 & -0.1 & 0.0 & -1.0 & -0.1 & 0.0 \\
\hline Food products \& beverages & -0.4 & -0.3 & -6.8 & -1.4 & 0.2 & -2.9 & -6.3 & -0.2 \\
\hline Tobacco products & -0.5 & -0.4 & -0.4 & -0.2 & -0.1 & -0.4 & -0.1 & -0.9 \\
\hline Textiles & -0.7 & -0.7 & -0.9 & -3.0 & -0.3 & -0.4 & -8.1 & -0.3 \\
\hline Wearing apparel & -0.8 & -0.7 & -0.2 & -7.3 & 0.0 & -0.5 & -10.8 & -0.4 \\
\hline Leather & -0.8 & -0.8 & -2.5 & -5.5 & 0.0 & -0.2 & -2.3 & -0.1 \\
\hline Wood \& of products & 0.0 & 0.0 & -0.8 & -0.3 & 0.0 & -1.0 & -0.1 & -0.2 \\
\hline Pulp, paper \& paper products & 0.2 & 0.2 & -0.5 & 0.0 & 0.1 & -0.8 & 0.0 & -0.2 \\
\hline $\begin{array}{l}\text { Publishing, printing \& reproduction of } \\
\text { recorded media }\end{array}$ & -0.3 & -0.3 & 0.0 & 0.0 & -0.1 & 0.0 & -0.2 & -0.6 \\
\hline Chemicals \& chemical products & 4.1 & 4.2 & -0.2 & -1.1 & 1.3 & -1.7 & -0.1 & 3.1 \\
\hline Rubber \& plastic & 0.8 & 0.8 & 0.3 & 0.7 & 0.7 & 0.0 & 0.1 & 1.1 \\
\hline Non-metallic mineral products & -0.2 & -0.2 & -0.1 & -0.5 & 0.0 & -0.3 & -0.1 & -0.1 \\
\hline Basic metals & -0.6 & -0.6 & -2.5 & -1.3 & -0.5 & -13.4 & -0.8 & -0.5 \\
\hline Metal products & -0.5 & -0.5 & -0.3 & -0.7 & -0.3 & -0.8 & -0.9 & -0.4 \\
\hline Machinery & -1.2 & -1.2 & -0.4 & 0.2 & 0.6 & -0.9 & -0.1 & 0.6 \\
\hline Office machinery \& computers & 0.9 & 0.9 & -0.1 & 1.2 & 3.1 & 0.0 & 0.5 & 2.9 \\
\hline Electrical machinery & 1.4 & 1.4 & 0.3 & 0.8 & 2.8 & 0.0 & 0.3 & 1.4 \\
\hline Radio, TV \& communication equipment & 2.7 & 2.8 & 1.2 & -2.2 & -0.9 & 0.0 & -0.1 & 3.7 \\
\hline Medical, precision \& optical instruments & 1.4 & 1.4 & 0.4 & -0.2 & 1.9 & 0.2 & 0.2 & 2.4 \\
\hline Motor vehicles, trailers \& semi-trailers & 1.5 & 1.5 & 0.3 & 0.0 & 1.8 & -0.5 & 0.4 & 0.2 \\
\hline Other transport equipment & 1.6 & 1.7 & -1.2 & 0.1 & 1.7 & -2.1 & -0.1 & 2.6 \\
\hline \multirow[t]{2}{*}{ Furniture; manufacturing n.e.c. } & 0.1 & 0.1 & 0.2 & -8.2 & -0.2 & 0.0 & 0.0 & 0.1 \\
\hline & \multicolumn{8}{|c|}{ Value } \\
\hline Agriculture, hunting & $\begin{array}{c}-0.4 \\
\end{array}$ & -0.4 & -6.8 & -1.1 & 0.0 & -0.5 & -4.8 & -0.8 \\
\hline Forestry, logging & 0.0 & 0.0 & -0.1 & 0.0 & 0.0 & -1.6 & -0.4 & -0.2 \\
\hline Fishing, fish farming & -0.1 & -0.1 & 0.0 & -0.2 & 0.0 & -1.0 & -0.1 & 0.0 \\
\hline Food products \& beverages & -0.6 & -0.6 & 0.0 & -1.9 & 0.2 & -2.5 & -5.8 & -0.2 \\
\hline Tobacco products & -0.1 & -0.1 & -0.2 & -0.1 & 0.0 & -0.1 & 0.0 & -0.3 \\
\hline Textiles & -1.1 & -1.1 & -1.0 & -4.2 & -0.7 & -0.6 & -11.6 & -0.4 \\
\hline Wearing apparel & -0.8 & -0.8 & -0.1 & -6.8 & 0.0 & -0.5 & -9.9 & -0.3 \\
\hline Leather & -0.9 & -0.9 & -3.1 & -5.6 & 0.0 & -0.3 & -2.2 & -0.2 \\
\hline Wood \& of products & 0.0 & 0.0 & -0.9 & -0.5 & 0.0 & -1.0 & -0.1 & -0.2 \\
\hline Pulp, paper \& paper products & 0.0 & 0.0 & -2.3 & 0.0 & 0.1 & -2.2 & 0.0 & -0.6 \\
\hline $\begin{array}{l}\text { Publishing, printing \& reproduction of } \\
\text { recorded media }\end{array}$ & 0.0 & 0.0 & 0.0 & -0.1 & 0.0 & 0.0 & 0.0 & 0.1 \\
\hline Chemicals \& chemical products & 7.0 & 7.1 & 0.0 & -1.2 & 1.6 & -2.2 & 1.2 & 4.2 \\
\hline Rubber \& plastic & 0.3 & 0.3 & 0.2 & -0.3 & 0.4 & 0.0 & -0.1 & 0.4 \\
\hline Non-metallic mineral products & -0.2 & -0.2 & -0.1 & -0.6 & 0.0 & -0.3 & -0.2 & 0.1 \\
\hline Basic metals & -0.8 & -0.8 & -2.6 & -1.5 & -0.6 & -17.5 & -1.0 & -0.7 \\
\hline Metal products & -0.3 & -0.3 & -0.2 & -0.6 & 0.0 & -0.5 & -0.8 & 0.0 \\
\hline Machinery & -1.2 & -1.2 & -0.4 & -0.6 & 0.2 & -0.8 & 0.0 & 0.9 \\
\hline Office machinery \& computers & 0.6 & 0.7 & 0.1 & 0.0 & 1.0 & 0.0 & 0.2 & 2.4 \\
\hline Electrical machinery & 0.2 & 0.2 & 0.1 & -1.0 & 0.8 & -0.2 & -0.3 & 0.1 \\
\hline Radio, TV \& communication equipment & 2.9 & 2.9 & 1.0 & -2.3 & -0.8 & 0.0 & -0.1 & 2.7 \\
\hline Medical, precision \& optical instruments & 1.1 & 1.1 & 0.2 & -0.2 & 2.2 & 0.0 & 0.1 & 2.1 \\
\hline Motor vehicles, trailers \& semi-trailers & 3.9 & 4.0 & 1.8 & -0.1 & 6.9 & 0.1 & 0.4 & 2.7 \\
\hline Other transport equipment & 2.6 & 2.7 & -1.7 & 0.1 & 1.0 & -1.1 & 0.0 & 4.4 \\
\hline Furniture; manufacturing n.e.c. & 0.0 & 0.0 & 0.0 & -5.5 & -0.2 & 0.0 & -0.2 & 0.0 \\
\hline
\end{tabular}


Cheptea, Gaulier, Sondjo and Zignago (2006), Study Report

Table 29: CTB by industry in 1995 and 2003 - European Countries

\begin{tabular}{|c|c|c|c|c|c|c|c|c|c|c|c|c|}
\hline & \multicolumn{12}{|c|}{1995} \\
\hline & AUT & BEL & CYP & CZE & DNK & EST & FIN & FRA & DEU & GRC & HUN & IRL \\
\hline Agriculture, hunting & -12.5 & -20.3 & 12.7 & -19.5 & -2.0 & -19.7 & -3.1 & -9.5 & -17.2 & 27.7 & 33.3 & -6.0 \\
\hline Forestry, logging & -0.6 & -0.3 & 0.2 & -0.3 & 4.2 & 13.9 & -13.3 & -1.0 & -0.3 & -2.0 & -0.4 & 0.5 \\
\hline Fishing, fish farming & -0.1 & -1.2 & 0.4 & 0.1 & -6.6 & 0.0 & -0.3 & -1.1 & -0.5 & 0.2 & 0.1 & 0.2 \\
\hline Food \& beverages & 3.2 & 7.6 & 31.6 & 6.4 & 22.3 & 63.4 & -3.0 & 15.1 & -4.1 & 49.8 & 54.5 & 48.4 \\
\hline Tobacco & 0.0 & -4.4 & -24.1 & -0.8 & 0.2 & -2.6 & -1.0 & 0.0 & 0.5 & 7.4 & -0.2 & 0.1 \\
\hline Textiles & -5.8 & 3.0 & -10.3 & 7.6 & -17.2 & 32.6 & -3.9 & -7.9 & -12.9 & 6.3 & -23.4 & -2.6 \\
\hline Wearing apparel & -18.5 & -12.8 & 8.7 & -5.0 & -23.0 & 3.5 & -8.0 & -22.1 & -30.4 & 17.1 & -5.4 & -3.8 \\
\hline Leather & -3.7 & -3.5 & 4.7 & 4.7 & -6.6 & 0.7 & -3.4 & -3.2 & -4.8 & -2.6 & -5.7 & -2.5 \\
\hline Wood & 6.8 & -4.6 & -1.4 & 1.1 & -3.7 & 2.0 & 12.2 & -2.6 & -3.2 & -1.7 & -0.1 & -3.8 \\
\hline Pulp \& paper & 12.6 & -4.6 & 2.6 & 3.0 & -1.8 & -8.1 & 64.2 & -0.9 & 3.2 & -1.1 & -1.4 & -1.5 \\
\hline Publishing \& printing & -0.3 & -0.5 & -0.4 & -3.3 & -0.3 & -1.6 & 1.2 & -0.2 & 0.7 & 0.4 & -0.8 & 11.2 \\
\hline Coke, refined petroleum & 0.0 & 0.0 & 0.0 & -16.8 & 0.0 & 0.0 & 0.0 & 0.1 & 0.3 & 0.0 & 0.0 & 0.0 \\
\hline Chemicals \& 11.4 & 34.9 & 32.9 & -31.2 & 78.9 & -8.2 & -6.8 & 26.7 & 43.4 & -22.3 & 6.1 & 128.9 & \\
\hline Rubber \& plastic & 5.8 & -1.1 & 0.2 & 7.8 & -1.9 & -3.9 & -0.7 & -0.6 & -0.9 & 8.3 & 3.3 & -3.7 \\
\hline Non-metallic mineral prod. & 22.7 & 1.5 & -1.5 & 40.8 & 0.5 & 0.4 & 2.6 & 4.4 & 1.3 & 12.6 & 3.3 & 1.5 \\
\hline Basic metals & -0.5 & 9.7 & 1.1 & 34.0 & -12.1 & -13.1 & -18.0 & -4.9 & -5.9 & 5.2 & -8.8 & 0.0 \\
\hline Metal products & 7.7 & 1.3 & 2.2 & 7.9 & -0.6 & 0.3 & 4.2 & 2.7 & -0.5 & 11.7 & -1.6 & -0.6 \\
\hline Machinery & 52.4 & 8.4 & -5.2 & 27.6 & 21.7 & -0.2 & 23.2 & 19.0 & 51.5 & -13.0 & -2.7 & -0.2 \\
\hline Office mach. \& computers & -36.0 & -7.4 & -2.8 & -56.1 & -22.7 & -26.1 & -32.8 & -47.4 & -41.5 & -6.4 & -22.7 & -126.8 \\
\hline Electrical machinery & 7.0 & -2.6 & -6.1 & 4.9 & 2.6 & -5.7 & -12.3 & 6.2 & -5.9 & 2.1 & 10.8 & -16.9 \\
\hline Radio, TV \& comm. equip. & -14.5 & -3.0 & -8.8 & -24.8 & -8.8 & -17.5 & 8.6 & -13.7 & -22.5 & -7.4 & -32.5 & -5.7 \\
\hline Medical, prec. \& opt. inst. & -9.7 & -8.9 & -4.3 & -25.5 & 1.3 & -2.0 & -9.0 & -12.6 & -4.8 & -11.4 & -4.6 & 4.7 \\
\hline Motor vehicles & -19.5 & 6.0 & -29.1 & 18.7 & -11.6 & 17.8 & -5.5 & 17.3 & 66.6 & -16.5 & 12.2 & -10.1 \\
\hline Other transport equipment & -6.9 & -6.9 & -5.3 & 12.5 & -17.6 & -41.0 & 7.8 & 42.9 & -2.7 & -58.6 & -12.4 & -13.0 \\
\hline Furniture; manuf. n.e.c. & -1.1 & -6.1 & 1.7 & 6.0 & 4.7 & 15.8 & -2.9 & -6.8 & -9.6 & -5.9 & -1.2 & 1.8 \\
\hline \multirow[t]{2}{*}{ Degree of specialisation } & 15.9 & 10.2 & 12.8 & 20.5 & 19.3 & 19.7 & 16.7 & 16.5 & 22.7 & 18.6 & 16.6 & 37.9 \\
\hline & ITA & LVA & LTU & MLT & NLD & POL & PRT & SVK & SVN & ESP & SWE & GBR \\
\hline Agriculture, hunting & -20.1 & -9.5 & -15.7 & -10.6 & -21.5 & -23.7 & -59.3 & -25.8 & -18.6 & -32.3 & -6.4 & -11.1 \\
\hline Forestry, logging & -2.1 & 12.4 & 7.1 & -0.3 & -0.8 & -0.7 & -9.4 & -1.3 & -0.5 & -1.0 & -2.2 & -0.2 \\
\hline Fishing, fish farming & -1.2 & -0.1 & 0.2 & 2.0 & -0.7 & -0.1 & -2.1 & 0.0 & -0.6 & -2.6 & -1.3 & 0.0 \\
\hline Food \& beverages & -4.2 & 27.9 & 41.7 & 6.8 & 36.2 & 30.4 & 15.6 & 5.7 & -14.4 & 1.9 & -11.8 & -1.1 \\
\hline Tobacco & 0.0 & 2.3 & -4.3 & -0.3 & 0.5 & -0.5 & 0.3 & 0.3 & -2.3 & -2.1 & 0.2 & 2.4 \\
\hline Textiles & 4.3 & 20.4 & 7.2 & -11.8 & -4.2 & -13.6 & 41.2 & -6.0 & -6.4 & -1.6 & -14.2 & -10.3 \\
\hline Wearing apparel & 0.3 & 7.5 & 5.4 & 0.2 & -15.5 & -10.8 & 38.7 & -1.4 & -5.3 & -7.4 & -19.7 & -12.6 \\
\hline Leather & 0.2 & -3.3 & 3.8 & -1.9 & -5.0 & -14.5 & 4.0 & 3.4 & 0.5 & 6.1 & -4.7 & -4.3 \\
\hline Wood & -7.5 & 3.5 & 4.5 & -4.3 & -12.3 & 4.6 & 33.9 & 4.8 & 0.0 & -2.7 & 3.7 & -5.7 \\
\hline Pulp \& paper & -6.1 & -17.6 & -9.3 & 0.1 & 0.8 & 9.4 & 11.5 & 4.4 & 6.1 & 0.3 & 14.1 & -1.2 \\
\hline Publishing \& printing & 0.5 & -1.2 & -0.8 & 18.8 & 8.1 & -4.4 & -1.4 & -3.1 & -1.6 & 4.4 & -2.3 & 3.1 \\
\hline Coke, refined petroleum & 0.0 & & 0.0 & 0.0 & 0.0 & 0.0 & 0.0 & 0.0 & -10.3 & -1.6 & -0.7 & 0.3 \\
\hline Chemicals & -26.4 & -13.7 & -29.0 & -21.8 & 43.6 & -6.9 & -17.9 & -63.0 & 56.4 & -3.6 & 10.8 & 46.2 \\
\hline Rubber \& plastic & 1.9 & -8.3 & -0.2 & 10.4 & -0.9 & -1.7 & -2.0 & 25.4 & 4.5 & 4.4 & -4.7 & -2.0 \\
\hline Non-metallic mineral prod. & 14.4 & -2.4 & 1.5 & 0.5 & -0.9 & 7.2 & 24.1 & 13.3 & 2.7 & 23.7 & -2.5 & 2.1 \\
\hline Basic metals & -31.2 & -16.6 & -39.9 & -11.0 & 0.5 & 58.2 & -14.3 & 87.4 & 0.9 & 9.1 & -6.0 & -0.1 \\
\hline Metal products & 9.2 & -8.5 & -2.6 & -2.1 & 0.7 & 4.9 & 10.9 & 5.1 & 13.2 & 7.2 & -0.7 & 0.1 \\
\hline Machinery & 69.5 & 6.9 & 16.8 & -20.7 & 16.4 & 8.4 & 10.5 & 12.5 & 18.4 & 17.7 & 16.1 & 27.3 \\
\hline Office mach. \& computers & -11.6 & -11.8 & -2.5 & -16.6 & -59.6 & -34.7 & -9.8 & -56.5 & -34.5 & -28.1 & -18.1 & -18.7 \\
\hline Electrical machinery & 2.2 & -10.1 & -6.8 & 18.6 & 5.9 & 5.2 & 2.2 & 2.6 & 3.5 & 4.6 & -14.4 & 2.6 \\
\hline Radio, TV \& comm. equip. & -11.2 & -4.0 & 12.8 & 154.1 & 14.7 & -28.7 & -47.4 & -28.4 & 0.9 & -17.1 & 48.8 & -20.5 \\
\hline Medical, prec. \& opt. inst. & -12.4 & -12.0 & 0.6 & -8.8 & -0.1 & -17.6 & -11.2 & -7.5 & -5.8 & -19.1 & -8.3 & -0.7 \\
\hline Motor vehicles & 12.9 & -9.9 & -6.7 & -21.6 & 1.5 & -4.6 & -24.0 & 19.4 & -22.4 & 28.7 & 43.9 & 11.7 \\
\hline Other transport equipment & -7.0 & 37.1 & 1.9 & -108.9 & -0.3 & 8.0 & 2.7 & 2.0 & -5.0 & 9.9 & -14.7 & 13.5 \\
\hline Furniture; manuf. n.e.c. & 25.8 & 11.0 & 13.0 & 29.2 & -7.4 & 25.7 & 3.8 & 6.6 & 20.9 & 1.7 & -5.0 & -10.2 \\
\hline Degree of specialisation & 18.6 & 14.0 & 14.7 & 39.7 & 18.2 & 18.8 & 22.6 & 27.3 & 16.4 & 13.6 & 16.3 & 13.7 \\
\hline
\end{tabular}


European Positioning in the International Division of Labour

\begin{tabular}{|c|c|c|c|c|c|c|c|c|c|c|c|c|}
\hline & \multicolumn{12}{|c|}{2003} \\
\hline & AUT & BEL & CYP & CZE & DNK & EST & FIN & FRA & DEU & GRC & HUN & IRL \\
\hline Agriculture, hunting & -10.2 & -19.9 & 1.5 & -11.6 & -0.6 & 8.1 & -5.1 & -5.3 & -14.4 & 30.0 & 13.7 & -5.0 \\
\hline Forestry, logging & -1.4 & -0.3 & 0.1 & 0.0 & 4.4 & 1.6 & -18.1 & -0.4 & -0.2 & -0.5 & -0.5 & -0.5 \\
\hline Fishing, fish farming & -0.1 & -0.5 & 1.1 & -0.1 & -10.1 & -0.4 & -2.0 & -1.6 & -0.5 & -1.1 & 0.0 & 0.2 \\
\hline Food \& beverages & 4.9 & 6.4 & 21.7 & 4.6 & 30.8 & 32.9 & -2.8 & 15.3 & -7.4 & 19.7 & 32.7 & 13.8 \\
\hline Tobacco & 1.3 & 0.3 & 20.9 & 0.5 & 0.2 & -0.3 & -0.2 & 0.4 & 0.6 & 10.2 & 0.0 & -0.1 \\
\hline Textiles & -6.5 & -2.4 & 1.8 & 3.0 & -16.7 & -2.5 & -6.0 & -9.5 & -12.9 & 11.2 & -4.5 & -3.2 \\
\hline Wearing apparel & -25.7 & -16.8 & -0.8 & -7.3 & -34.3 & 3.4 & -13.0 & -27.5 & -25.2 & 15.3 & -6.8 & -8.1 \\
\hline Leather & -8.3 & -8.6 & -1.3 & -6.4 & -7.3 & -2.7 & -4.2 & -5.0 & -5.9 & -4.4 & -3.9 & -2.1 \\
\hline Wood & 10.4 & -1.2 & -1.9 & 4.1 & -5.6 & 15.0 & 14.1 & -1.9 & -0.8 & -2.9 & -0.4 & -4.3 \\
\hline Pulp \& paper & 11.6 & -2.5 & 4.8 & 8.9 & 1.7 & 33.0 & 60.1 & -0.2 & 1.2 & 1.4 & 5.4 & -5.9 \\
\hline Publishing \& printing & 2.3 & 0.7 & 1.2 & 1.6 & 1.7 & 1.1 & 0.4 & 1.7 & 1.8 & 2.4 & -0.1 & 5.8 \\
\hline Coke, refined petroleum & 0.0 & 0.0 & 0.0 & -2.3 & 0.0 & -0.2 & -0.4 & -0.7 & -0.4 & 0.0 & -2.3 & 0.0 \\
\hline Chemicals & 18.2 & 31.3 & 19.6 & -4.4 & 88.5 & 15.2 & -4.4 & 25.3 & 33.4 & 12.0 & 40.9 & 188.8 \\
\hline Rubber \& plastic & 2.3 & -2.0 & -2.1 & 4.6 & 0.1 & 5.4 & -0.9 & -1.3 & 1.0 & 9.1 & 6.5 & -5.4 \\
\hline Non-metallic mineral prod. & 13.0 & 0.1 & -2.2 & 36.5 & -2.8 & 1.4 & 3.4 & 3.1 & 1.7 & 4.7 & 4.2 & -1.3 \\
\hline Basic metals & -2.1 & 6.7 & -1.9 & 12.2 & -13.3 & -14.5 & -19.2 & -2.0 & -3.3 & 15.0 & -5.0 & -3.6 \\
\hline Metal products & 5.0 & -0.1 & -2.6 & 13.4 & -0.2 & 12.0 & 3.2 & 1.3 & 1.5 & 10.1 & 3.4 & -3.2 \\
\hline Machinery & 51.8 & 10.2 & -7.3 & 46.9 & 22.6 & -4.7 & 26.6 & 16.1 & 50.2 & -4.8 & -0.4 & -19.0 \\
\hline Office mach. \& computers & -24.5 & -12.6 & -3.9 & -54.7 & -16.9 & -13.8 & -24.1 & -32.6 & -39.4 & -1.9 & -2.3 & -59.2 \\
\hline Electrical machinery & -3.9 & 0.6 & -3.7 & 1.6 & 9.1 & -18.8 & -0.7 & 2.7 & 1.4 & 3.9 & -9.0 & -19.6 \\
\hline Radio, TV \& comm. equip. & -29.8 & -12.1 & -3.2 & -62.5 & -11.7 & -26.1 & 3.9 & -16.1 & -32.5 & 1.2 & -77.5 & -26.1 \\
\hline Medical, prec. \& opt. inst. & -9.0 & -8.3 & -1.8 & -12.4 & 7.7 & 2.6 & 1.4 & -9.4 & -1.0 & -6.2 & 0.0 & 5.9 \\
\hline Motor vehicles & -0.4 & 7.9 & -24.5 & 22.6 & -7.6 & -3.5 & -16.1 & 16.5 & 70.7 & -17.0 & 22.7 & -12.2 \\
\hline Other transport equipment & 0.4 & -8.3 & -60.0 & -3.0 & -35.7 & -53.0 & 9.9 & 40.1 & -11.5 & -103.4 & -15.0 & -31.5 \\
\hline Furniture; manuf. n.e.c. & 1.0 & 1.0 & 43.0 & 3.6 & -4.4 & 8.9 & -6.0 & -8.9 & -8.0 & -4.8 & -1.9 & -4.1 \\
\hline \multirow[t]{2}{*}{ Degree of specialisation } & 15.4 & 11.6 & 17.3 & 21.8 & 22.8 & 17.0 & 16.1 & 14.7 & 22.4 & 23.2 & 20.0 & 41.1 \\
\hline & ITA & LVA & LTU & MLT & NLD & POL & PRT & SVK & SVN & ESP & SWE & GBR \\
\hline Agriculture, hunting & -18.8 & -14.2 & 4.3 & 0.2 & -4.4 & -9.6 & -57.1 & -16.5 & -16.4 & -19.9 & -6.4 & -8.3 \\
\hline Forestry, logging & -1.5 & -2.6 & 1.0 & 0.0 & -0.7 & -0.9 & -4.8 & -0.8 & -3.2 & -0.1 & -2.7 & -0.2 \\
\hline Fishing, fish farming & -1.2 & -2.4 & -0.9 & 2.9 & -0.4 & -1.7 & -2.8 & 0.0 & -0.6 & -2.7 & -7.0 & 0.0 \\
\hline Food \& beverages & 0.9 & 13.8 & 29.4 & -6.4 & 34.2 & 32.3 & -8.1 & -1.4 & 2.1 & -1.6 & -11.4 & -0.3 \\
\hline Tobacco & 0.0 & 1.3 & -0.6 & -0.2 & 1.2 & 2.6 & -0.1 & 0.7 & -1.0 & -0.7 & 0.1 & 2.8 \\
\hline Textiles & 2.4 & -1.3 & -6.5 & -7.5 & -1.7 & -16.5 & 17.3 & -18.6 & -3.9 & -2.6 & -13.5 & -9.7 \\
\hline Wearing apparel & -9.8 & 7.7 & 4.3 & -10.5 & -11.7 & -8.4 & 14.3 & -7.9 & -9.6 & -18.0 & -20.5 & -24.6 \\
\hline Leather & -2.9 & -6.4 & -5.1 & -1.0 & -3.7 & -6.2 & 2.0 & -6.3 & -22.0 & -3.7 & -5.8 & -7.2 \\
\hline Wood & -6.2 & 51.2 & 6.1 & -1.1 & -3.0 & 11.0 & 25.4 & 2.8 & 2.8 & -4.3 & 7.5 & -4.1 \\
\hline Pulp \& paper & -4.7 & -1.8 & 4.0 & -0.3 & 4.3 & 17.3 & 15.9 & 8.1 & 11.7 & 3.5 & 21.5 & -0.6 \\
\hline Publishing \& printing & 1.3 & -3.5 & -0.2 & -0.2 & 7.3 & 1.6 & 0.1 & 3.4 & 1.6 & 5.9 & 3.0 & 4.7 \\
\hline Coke, refined petroleum & 0.0 & 0.0 & -14.2 & 0.0 & 1.4 & 0.0 & -0.1 & -9.8 & -3.9 & -0.2 & -0.5 & 4.2 \\
\hline Chemicals & -6.0 & 14.0 & -48.3 & -15.9 & 48.3 & -14.6 & -6.5 & -30.0 & 54.0 & 28.5 & 7.8 & 46.3 \\
\hline Rubber \& plastic & 2.7 & -1.7 & 3.8 & -1.6 & 0.5 & 8.9 & 1.2 & 0.1 & 11.4 & 3.7 & -2.7 & -1.0 \\
\hline Non-metallic mineral prod. & 12.7 & 1.1 & 1.0 & -1.5 & 1.0 & 11.1 & 17.6 & 9.2 & 3.8 & 20.2 & -1.5 & 0.9 \\
\hline Basic metals & -42.6 & -5.4 & -11.0 & -8.6 & -9.3 & 14.2 & -41.0 & 24.6 & -22.9 & -9.6 & -4.5 & -14.2 \\
\hline Metal products & 8.5 & 5.0 & -1.8 & -7.2 & 1.8 & 5.7 & 11.3 & 9.2 & 10.1 & 6.0 & 2.2 & 0.5 \\
\hline Machinery & 77.1 & -18.1 & -5.6 & -7.1 & 24.7 & 5.5 & 10.5 & -4.6 & 31.7 & 11.5 & 34.1 & 24.1 \\
\hline Office mach. \& computers & -6.3 & -10.3 & -21.7 & 4.7 & -66.6 & -38.7 & 12.0 & -34.9 & -27.9 & -11.7 & -6.1 & -14.8 \\
\hline Electrical machinery & 2.3 & 4.4 & -4.6 & 5.6 & -0.3 & 0.2 & 7.9 & -21.2 & -0.6 & 3.3 & -3.2 & 3.5 \\
\hline Radio, TV \& comm. equip. & -9.7 & 0.0 & 8.2 & 297.6 & -44.3 & -34.9 & 28.6 & -57.0 & -7.0 & -24.0 & 12.0 & -19.6 \\
\hline Medical, prec. \& opt. inst. & -5.2 & -8.8 & -3.8 & -8.0 & 16.9 & -7.6 & -10.9 & -14.6 & -3.8 & -12.5 & -6.1 & 4.9 \\
\hline Motor vehicles & -5.0 & -10.1 & 41.2 & -19.3 & 12.1 & -2.1 & -15.4 & 182.2 & -9.1 & 20.0 & 35.8 & 20.3 \\
\hline Other transport equipment & -5.9 & -10.9 & 6.3 & -207.4 & -1.3 & 13.0 & -16.2 & -16.3 & -6.2 & 13.2 & -24.7 & 8.5 \\
\hline Furniture; manuf. n.e.c. & 17.9 & -0.7 & 14.7 & -7.6 & -6.5 & 17.1 & -1.1 & -0.4 & 9.0 & -4.1 & -7.9 & -14.6 \\
\hline Degree of specialisation & 19.1 & 12.9 & 15.8 & 74.4 & 21.3 & 15.3 & 18.6 & 40.6 & 16.5 & 12.3 & 13.9 & 14.4 \\
\hline
\end{tabular}

Note: See notes for Table 9 (page 32). Country codes are shown in Table 18 of Appendix A2. 
Table 30: Market Shares by industry and quality in 2003 and change 1995-2003 (Sum of the line for $2003=100)$

\begin{tabular}{|c|c|c|c|c|c|c|c|c|c|c|c|c|c|c|}
\hline & \multicolumn{2}{|c|}{ EU25 } & \multicolumn{2}{|c|}{ USA } & \multicolumn{2}{|c|}{ Japan } & \multicolumn{2}{|c|}{ Russia } & \multicolumn{2}{|c|}{ Korea } & \multicolumn{2}{|c|}{ China } & \multicolumn{2}{|c|}{ RoW } \\
\hline & 2003 & $\Delta$ & 2003 & $\Delta$ & 2003 & $\Delta$ & 2003 & $\Delta$ & 2003 & $\Delta$ & 2003 & $\Delta$ & 2003 & $\Delta$ \\
\hline \multicolumn{15}{|c|}{ Agriculture, hunting } \\
\hline Low-market & 7.7 & -0.4 & 9.3 & -8.7 & 0.2 & 0.0 & 2.3 & 1.1 & 0.1 & 0.0 & 8.5 & 2.0 & 71.9 & 6.1 \\
\hline Mid-market & 5.8 & 0.1 & 34.4 & -3.1 & 0.1 & 0.0 & 0.5 & 0.0 & 0.1 & 0.1 & 5.0 & 2.8 & 54.1 & 0.1 \\
\hline Up-market & 17.4 & 1.1 & 19.7 & -1.4 & 0.7 & -0.2 & 0.8 & 0.7 & 0.8 & -0.4 & 4.7 & -0.2 & 56.0 & 0.5 \\
\hline \multicolumn{15}{|c|}{ Forestry, logging } \\
\hline Low-market & 6.2 & -0.8 & 7.5 & -3.4 & 0.2 & 0.1 & 38.8 & 14.8 & 0.1 & 0.1 & 4.1 & 1.9 & 43.1 & -12.6 \\
\hline Mid-market & 15.1 & 3.2 & 18.5 & 3.8 & 0.3 & 0.1 & 19.4 & 17.9 & 0.4 & 0.2 & 2.5 & 1.5 & 43.8 & -26.7 \\
\hline Up-market & 22.3 & 12.7 & 29.5 & -16.5 & 0.8 & -0.1 & 0.5 & 0.5 & 1.1 & -0.5 & 1.6 & -0.8 & 44.1 & 4.7 \\
\hline \multicolumn{15}{|c|}{ Fishing, fish farming } \\
\hline Low-market & 2.3 & -0.9 & 9.0 & 0.7 & 3.2 & 1.5 & 1.5 & -4.1 & 0.3 & -0.2 & 20.5 & 4.0 & 63.2 & -1.0 \\
\hline Mid-market & 1.6 & 0.3 & 9.4 & 3.2 & 1.2 & 1.0 & 0.2 & -0.4 & 5.1 & -1.1 & 2.1 & -1.8 & 80.3 & -1.4 \\
\hline Up-market & 11.6 & 5.5 & 5.7 & -6.5 & 2.6 & -1.7 & 1.1 & -4.0 & 6.0 & -6.1 & 1.9 & -7.5 & 71.1 & 20.3 \\
\hline \multicolumn{15}{|c|}{ Food products \& beverages } \\
\hline Low-market & 13.1 & -6.9 & 13.1 & -1.0 & 0.4 & 0.1 & 1.1 & -0.6 & 0.9 & 0.1 & 8.0 & 2.7 & 63.5 & 5.4 \\
\hline Mid-market & 15.7 & -7.0 & 12.4 & -2.9 & 0.4 & -0.1 & 1.0 & -0.2 & 0.3 & -0.5 & 4.8 & 1.6 & 65.5 & 9.0 \\
\hline Up-market & 32.9 & 2.8 & 13.8 & 0.8 & 1.9 & -0.4 & 1.3 & 0.0 & 1.4 & -0.8 & 2.8 & -1.1 & 46.1 & -1.1 \\
\hline \multicolumn{15}{|c|}{ Tobacco products } \\
\hline Low-market & 22.9 & 2.5 & 9.8 & -13.4 & 4.4 & 3.5 & 3.8 & 3.8 & 5.3 & 4.9 & 2.8 & -4.2 & 50.9 & 2.7 \\
\hline Mid-market & 41.7 & 22.4 & 10.3 & -19.4 & 3.6 & -3.0 & 1.3 & 1.3 & 2.3 & 1.3 & 10.3 & -8.1 & 30.6 & 5.5 \\
\hline Up-market & 11.8 & -7.8 & 66.3 & 1.6 & 0.1 & -2.7 & 0.0 & 0.0 & 0.1 & 0.0 & 0.2 & 0.1 & 21.6 & 8.7 \\
\hline \multicolumn{15}{|l|}{ Textiles } \\
\hline Low-market & 3.7 & -2.1 & 4.4 & -0.7 & 0.5 & -0.2 & 0.6 & 0.1 & 5.3 & -3.2 & 34.0 & 5.9 & 51.5 & 0.0 \\
\hline Mid-market & 11.0 & -1.8 & 7.4 & 0.0 & 1.6 & -1.1 & 0.2 & 0.1 & 8.4 & -4.8 & 19.7 & 7.7 & 51.7 & -0.1 \\
\hline Up-market & 31.0 & -0.8 & 8.6 & 0.2 & 9.1 & -4.8 & 0.1 & 0.1 & 4.4 & -2.7 & 6.8 & 1.4 & 40.1 & 6.7 \\
\hline \multicolumn{15}{|c|}{ Wearing apparel } \\
\hline Low-market & 1.5 & -0.5 & 2.5 & -3.1 & 0.1 & 0.0 & 0.5 & 0.2 & 1.2 & -0.2 & 47.1 & 6.2 & 47.3 & -2.5 \\
\hline Mid-market & 3.4 & -1.3 & 1.5 & -0.8 & 0.1 & -0.1 & 0.2 & -0.1 & 2.4 & -3.1 & 21.9 & 6.1 & 70.5 & -0.8 \\
\hline Up-market & 25.5 & -5.3 & 2.2 & -2.8 & 0.9 & -0.7 & 0.2 & 0.1 & 1.7 & -3.5 & 9.7 & 2.2 & 59.8 & 10.0 \\
\hline \multicolumn{15}{|l|}{ Leather } \\
\hline Low-market & 4.1 & -2.3 & 2.2 & -0.5 & 0.1 & -0.2 & 0.6 & 0.0 & 2.0 & -1.7 & 55.6 & 9.0 & 35.5 & -4.3 \\
\hline Mid-market & 11.5 & -8.6 & 3.4 & 0.8 & 0.1 & -0.6 & 0.2 & 0.1 & 5.7 & -1.8 & 18.2 & -0.7 & 60.9 & 10.8 \\
\hline Up-market & 43.6 & 3.8 & 3.6 & -1.0 & 1.0 & -0.5 & 0.3 & 0.2 & 1.1 & -9.0 & 15.1 & 6.2 & 35.3 & 0.2 \\
\hline Wood \& woo & product & & & & & & & & & & & & & \\
\hline Low-market & 7.5 & 3.2 & 4.0 & -1.2 & 0.1 & 0.0 & 5.9 & 4.2 & 0.1 & -0.1 & 11.8 & 6.3 & 70.6 & -12.4 \\
\hline Mid-market & 16.7 & 6.1 & 9.7 & -1.3 & 0.0 & -0.1 & 5.7 & 0.4 & 0.1 & -0.2 & 9.5 & 1.7 & 58.3 & -6.5 \\
\hline Up-market & 34.3 & 13.8 & 10.7 & -10.2 & 0.5 & -0.3 & 0.4 & 0.3 & 0.4 & -0.1 & 9.0 & 5.1 & 44.7 & -8.5 \\
\hline Pulp, paper \& & aper pr & lucts & & & & & & & & & & & & \\
\hline Low-market & 21.5 & 3.8 & 14.2 & -19.2 & 2.1 & 0.9 & 4.9 & 3.2 & 4.4 & 0.5 & 5.7 & 2.3 & 47.3 & 8.6 \\
\hline Mid-market & 20.3 & 0.2 & 19.8 & 0.8 & 2.0 & -0.4 & 1.7 & -0.6 & 1.7 & 0.7 & 1.0 & 0.5 & 53.5 & -1.3 \\
\hline Up-market & 36.5 & 1.4 & 21.4 & 4.6 & 8.2 & -1.3 & 0.4 & 0.0 & 0.8 & -0.5 & 3.9 & 2.7 & 28.8 & -7.1 \\
\hline Publishing, $p$ & ting \& & product & of of rec & orded m & & & & & & & & & & \\
\hline Low-market & 15.9 & -11.9 & 19.3 & -3.9 & 1.8 & 0.2 & 0.7 & 0.6 & 1.5 & -0.4 & 12.9 & 7.6 & 47.9 & 7.7 \\
\hline Mid-market & 31.5 & 1.7 & 30.8 & -10.4 & 1.9 & -2.2 & 0.4 & 0.4 & 1.9 & 1.0 & 12.3 & 10.7 & 21.3 & -1.3 \\
\hline Up-market & 46.3 & 2.0 & 28.4 & 0.5 & 3.4 & -3.2 & 1.5 & 1.2 & 0.6 & 0.3 & 1.9 & 1.1 & 17.8 & -1.9 \\
\hline Chemicals \& & hemical & roducts & & & & & & & & & & & & \\
\hline Low-market & 24.5 & -1.2 & 17.5 & -2.9 & 4.5 & -0.8 & 2.6 & 0.5 & 4.5 & -0.2 & 8.2 & 2.1 & 38.3 & 2.5 \\
\hline Mid-market & 27.4 & -0.1 & 18.5 & -3.4 & 8.6 & -3.5 & 1.5 & -0.3 & 6.2 & 1.9 & 2.6 & 0.5 & 35.2 & 5.0 \\
\hline Up-market & 44.1 & 5.8 & 18.9 & 3.2 & 12.5 & -4.0 & 0.4 & 0.1 & 0.7 & -0.4 & 1.1 & 0.2 & 22.4 & -4.9 \\
\hline Rubber \& pla & & & & & & & & & & & & & & \\
\hline Low-market & 9.6 & -1.0 & 16.9 & -1.1 & 2.3 & -1.9 & 1.0 & 0.9 & 5.2 & -3.0 & 23.3 & 8.9 & 41.8 & -2.8 \\
\hline Mid-market & 23.1 & 4.6 & 12.4 & -2.9 & 11.1 & -0.3 & 0.2 & 0.2 & 4.9 & 2.1 & 7.5 & 4.4 & 40.9 & -8.0 \\
\hline Up-market & 30.7 & -3.1 & 18.1 & 1.6 & 22.5 & -3.1 & 0.4 & 0.3 & 2.3 & 0.8 & 2.8 & 1.3 & 23.2 & 2.2 \\
\hline
\end{tabular}


European Positioning in the International Division of Labour

\begin{tabular}{|c|c|c|c|c|c|c|c|c|c|c|c|c|c|c|}
\hline & \multicolumn{2}{|c|}{ EU25 } & \multicolumn{2}{|c|}{ USA } & \multicolumn{2}{|c|}{ Japan } & \multicolumn{2}{|c|}{ Russia } & \multicolumn{2}{|c|}{ Korea } & \multicolumn{2}{|c|}{ China } & \multicolumn{2}{|c|}{ RoW } \\
\hline & 2003 & $\Delta$ & 2003 & $\Delta$ & 2003 & $\Delta$ & 2003 & $\Delta$ & 2003 & $\Delta$ & 2003 & $\Delta$ & 2003 & $\Delta$ \\
\hline \multicolumn{15}{|c|}{ Non-metallic mineral products } \\
\hline Low-market & $18.6^{1}$ & -6.1 & 7.9 & -2.5 & 3.3 & -0.4 & 1.5 & 0.8 & 2.7 & 1.3 & 24.0 & 8.6 & 42.0 & -1.8 \\
\hline Mid-market & 43.4 & -3.1 & 12.6 & -2.1 & 8.4 & -2.6 & 0.4 & 0.4 & 1.2 & -0.2 & 6.3 & 2.7 & 27.8 & 5.0 \\
\hline Up-market & 43.1 & -4.5 & 12.7 & 2.1 & 15.6 & -6.4 & 0.4 & 0.4 & 1.6 & -0.5 & 5.4 & 2.2 & 21.3 & 6.7 \\
\hline \multicolumn{15}{|l|}{ Basic metals } \\
\hline Low-market & 10.4 & -3.8 & 5.8 & -3.4 & 6.2 & 0.0 & 12.2 & 0.3 & 3.6 & 0.3 & 5.6 & 0.0 & 56.1 & 6.5 \\
\hline Mid-market & 11.9 & -2.5 & 7.2 & -3.0 & 9.2 & -0.3 & 7.5 & 0.9 & 4.6 & -0.4 & 3.5 & 0.0 & 56.0 & 5.3 \\
\hline Up-market & 23.6 & -5.6 & 14.5 & 0.6 & 11.2 & -8.1 & 2.6 & 1.4 & 2.9 & 0.2 & 1.1 & 0.1 & 44.3 & 11.3 \\
\hline \multicolumn{15}{|c|}{ Metal products } \\
\hline Low-market & 12.2 & -3.8 & 8.7 & -3.8 & 2.4 & -2.0 & 1.4 & 0.9 & 4.0 & -1.5 & 32.6 & 14.3 & 38.7 & -4.2 \\
\hline Mid-market & 30.3 & 1.4 & 10.6 & -11.5 & 7.3 & -2.3 & 0.4 & 0.3 & 4.3 & -1.9 & 6.8 & 2.3 & 40.3 & 11.6 \\
\hline Up-market & 35.8 & -2.2 & 22.7 & 7.7 & 13.4 & -5.3 & 0.8 & 0.6 & 2.3 & -3.2 & 2.9 & 1.8 & 22.1 & 0.6 \\
\hline \multicolumn{15}{|l|}{ Machinery } \\
\hline Low-market & 23.6 & -8.6 & 13.8 & -3.7 & 8.8 & -2.1 & 0.9 & 0.5 & 5.8 & 1.0 & 17.4 & 10.3 & 29.8 & 2.7 \\
\hline Mid-market & 42.3 & 1.9 & 11.8 & -4.5 & 22.2 & -4.1 & 0.2 & 0.2 & 4.2 & 1.7 & 3.5 & 2.7 & 15.8 & 2.0 \\
\hline Up-market & 39.5 & 1.8 & 17.0 & 0.3 & 19.9 & -6.8 & 0.4 & 0.3 & 1.5 & 0.6 & 1.2 & 0.7 & 20.6 & 3.1 \\
\hline \multicolumn{15}{|c|}{ Office machinery \& computers } \\
\hline Low-market & 2.4 & -3.0 & 4.7 & -8.9 & 6.6 & 1.5 & 0.0 & 0.0 & 1.8 & -4.0 & 44.3 & 32.1 & 40.2 & -17.7 \\
\hline Mid-market & 9.7 & -1.7 & 7.0 & -13.3 & 10.6 & -18.9 & 0.0 & 0.0 & 7.9 & 6.0 & 11.4 & 9.9 & 53.4 & 18.0 \\
\hline Up-market & 15.3 & 2.1 & 21.2 & -7.1 & 12.0 & -21.4 & 0.1 & 0.1 & 10.0 & 6.4 & 5.6 & 5.1 & 35.9 & 14.9 \\
\hline \multicolumn{15}{|c|}{ Electrical machinery } \\
\hline Low-market & 10.5 & -6.3 & 12.8 & -3.1 & 4.5 & -0.5 & 0.6 & 0.3 & 3.3 & -0.1 & 25.0 & 9.5 & 43.4 & 0.2 \\
\hline Mid-market & 28.1 & -1.2 & 11.8 & -4.9 & 16.4 & -4.3 & 0.4 & 0.3 & 3.7 & 0.8 & 15.4 & 8.9 & 24.3 & 0.4 \\
\hline Up-market & 28.2 & 2.0 & 14.4 & 0.9 & 23.1 & -11.6 & 0.4 & 0.3 & 2.1 & -3.5 & 5.1 & 3.1 & 26.7 & 8.8 \\
\hline \multicolumn{15}{|c|}{ Radio, TV \& communication equipment } \\
\hline Low-market & 6.7 & 0.8 & 10.6 & 1.8 & 5.2 & -12.9 & 0.0 & 0.0 & 6.0 & -2.6 & 26.8 & 14.3 & 44.7 & -1.4 \\
\hline Mid-market & 13.8 & -1.5 & 5.6 & -11.8 & 14.1 & -7.8 & 0.0 & 0.0 & 16.5 & 8.5 & 15.8 & 12.9 & 34.2 & -0.3 \\
\hline Up-market & 17.5 & -3.0 & 10.4 & -5.7 & 21.7 & -8.4 & 0.1 & 0.1 & 16.9 & 2.2 & 4.9 & 4.0 & 28.5 & 10.9 \\
\hline \multicolumn{15}{|c|}{ Medical, precision \& optical instruments } \\
\hline Low-market & 16.2 & -4.5 & 21.2 & -5.5 & 13.1 & -2.8 & 0.5 & 0.4 & 3.1 & 0.4 & 14.7 & 4.3 & 31.2 & 7.7 \\
\hline Mid-market & 30.9 & 2.1 & 23.8 & -7.9 & 25.4 & 0.6 & 0.2 & 0.2 & 1.7 & 0.5 & 4.5 & 2.8 & 13.4 & 1.9 \\
\hline Up-market & 33.2 & 3.6 & 22.7 & 0.0 & 16.6 & -11.8 & 0.6 & 0.5 & 0.6 & -0.5 & 1.9 & 1.3 & 24.5 & 6.9 \\
\hline \multicolumn{15}{|c|}{ Motor vehicles, trailers \& semi-trailers } \\
\hline Low-market & 10.8 & -2.0 & 12.5 & -7.8 & 18.8 & 2.3 & 0.8 & 0.4 & 12.6 & 5.6 & 1.7 & 1.1 & 42.8 & 0.5 \\
\hline Mid-market & 21.8 & 8.2 & 13.1 & -4.5 & 42.5 & -9.3 & 0.0 & 0.0 & 0.8 & -1.3 & 0.5 & 0.3 & 21.3 & 6.7 \\
\hline Up-market & 45.1 & 2.3 & 13.1 & -0.1 & 15.2 & -11.3 & 0.2 & 0.2 & 1.0 & 0.5 & 0.6 & 0.1 & 24.8 & 8.3 \\
\hline \multicolumn{15}{|c|}{ Other transport equipment } \\
\hline Low-market & 15.9 & 0.8 & 30.1 & 2.7 & 15.1 & 4.5 & 3.0 & 2.2 & 7.0 & -7.9 & 6.6 & 2.7 & 22.3 & -5.0 \\
\hline Mid-market & 22.8 & 0.1 & 30.7 & 7.2 & 11.1 & -24.0 & 1.4 & 1.3 & 8.8 & 5.6 & 2.0 & 1.1 & 23.3 & 8.7 \\
\hline Up-market & 37.4 & -4.8 & 27.0 & -1.6 & 4.9 & -5.8 & 2.0 & 1.9 & 5.2 & 3.7 & 2.0 & 1.3 & 21.5 & 5.2 \\
\hline \multicolumn{15}{|c|}{ Furniture; manufacturing n.e.c. } \\
\hline Low-market & 5.4 & -5.2 & 5.2 & -1.7 & 1.4 & -0.8 & 0.4 & 0.2 & 1.3 & -1.8 & 51.9 & 14.6 & 34.4 & -5.3 \\
\hline Mid-market & 18.8 & -1.0 & 4.7 & -5.7 & 4.3 & -1.7 & 0.1 & 0.1 & 2.2 & -1.8 & 36.8 & 8.0 & 33.1 & 2.1 \\
\hline Up-market & 31.2 & -2.5 & 8.8 & -1.6 & 10.7 & -7.8 & 0.2 & 0.2 & 1.6 & -1.6 & 23.2 & 12.3 & 24.5 & 0.9 \\
\hline
\end{tabular}


Figure 6: Evolution of CTB by industry

Evolution of CTB by industry - China

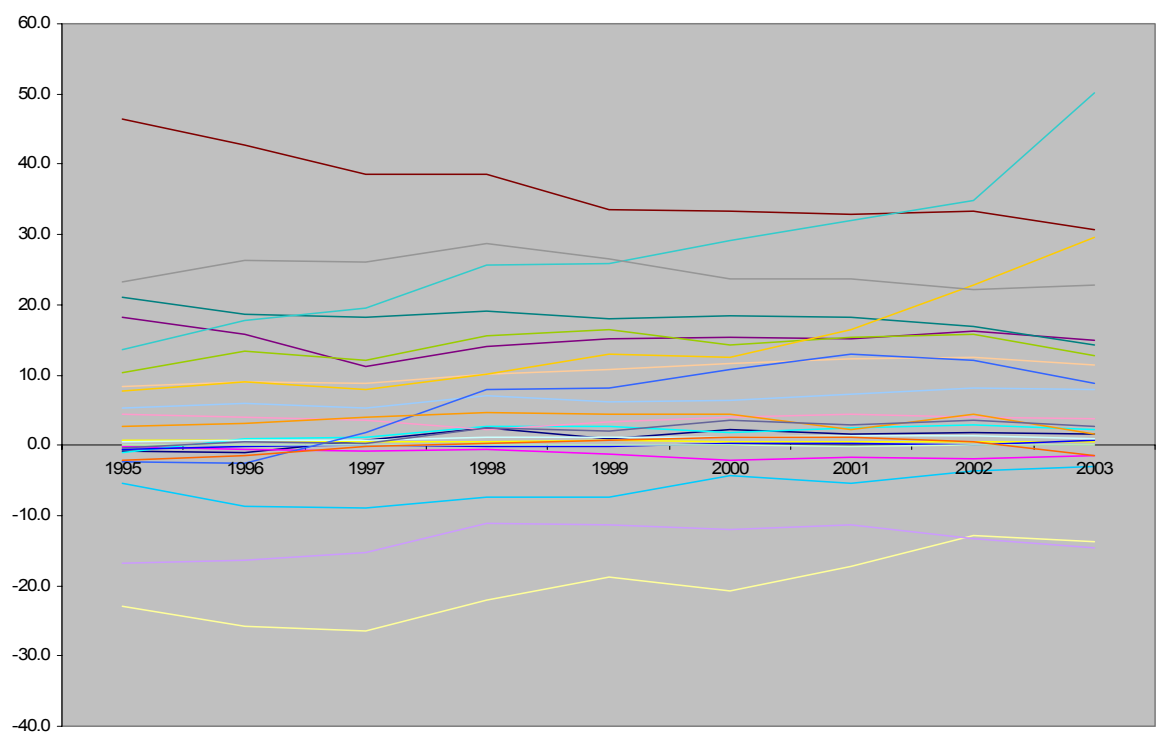

\begin{tabular}{|l|}
\hline - Agriculture, hunting \\
- Forestry, logging \\
Fishing, fish farming \\
Food \& beverages \\
— Textiles \\
— Wearing apparel \\
— Leather \\
- Wood \\
Pulp \& paper \\
Publishing \& printing \\
Coke, refined petroleum \\
Chemicals \\
Rubber \& plastic \\
Non-metallic mineral prod. \\
Basic metals \\
Metal products \\
Machinery \\
Office mach. \& computers \\
\hline Bectrical machinery \\
Radio, TV \& corm equip. \\
Medical, prec. \& opt. inst. \\
Mbtor vehicles \\
\hline Other transport equipment \\
Furniture; manuf. n.e.c. \\
\hline
\end{tabular}

Evolution of CTB by industry - Korea

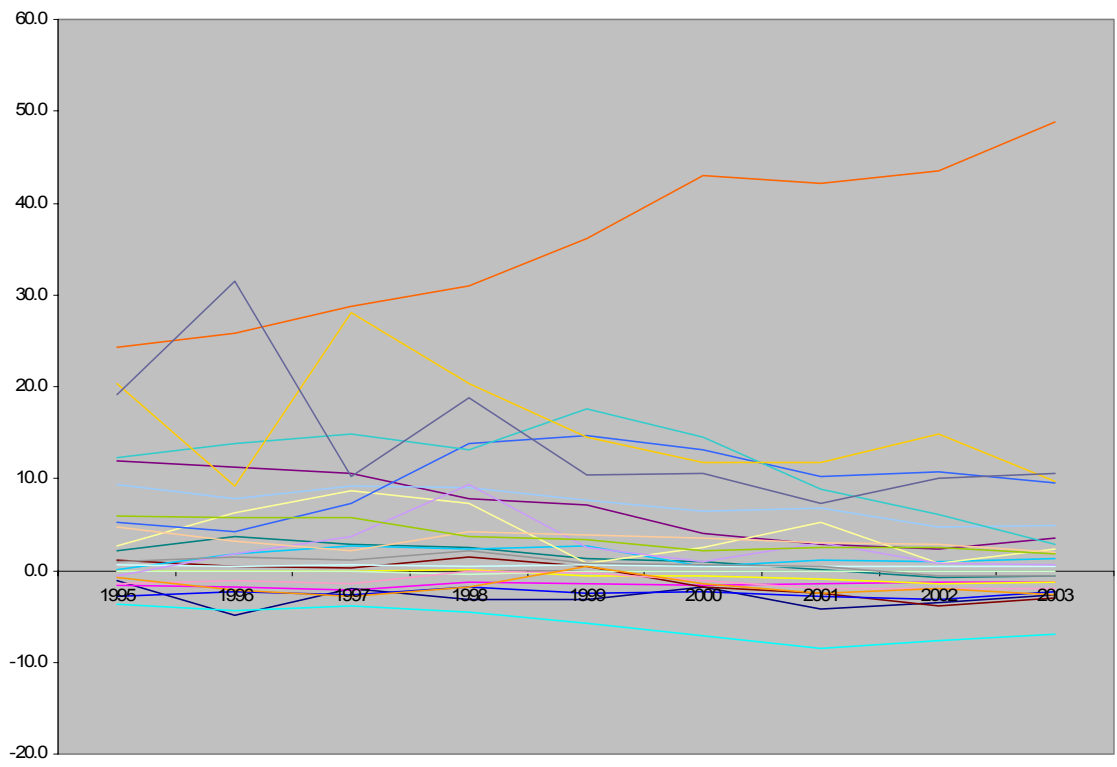

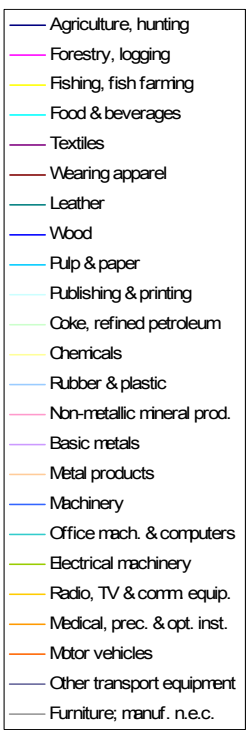


European Positioning in the International Division of Labour

Table 32: Market Shares by stages and quality in 2003 and change over 1995-2003 (Sum of the column for 2003 and a particular market=100)

\begin{tabular}{|c|c|c|c|c|c|c|c|c|c|c|c|}
\hline & & \multicolumn{2}{|c|}{ Consumption } & \multicolumn{2}{|c|}{ Capital } & \multicolumn{2}{|c|}{ Primary } & \multicolumn{2}{|c|}{$\begin{array}{l}\text { Parts and } \\
\text { components }\end{array}$} & \multicolumn{2}{|c|}{ Transformed } \\
\hline & & 2003 & $\Delta$ & 2003 & $\Delta$ & 2003 & $\Delta$ & 2003 & $\Delta$ & 2003 & $\Delta$ \\
\hline \multirow{3}{*}{ EU25 } & Low-market & 9.2 & -1.9 & 18.4 & 0.3 & 11.7 & 3.4 & 13.1 & -4.4 & 13.7 & -1.7 \\
\hline & Mid-market & 18.7 & 2.9 & 32.9 & 5.1 & 6.9 & 1.3 & 23.5 & 2.2 & 17.7 & 1.0 \\
\hline & Up-market & 38.0 & 2.8 & 31.6 & 5.0 & 15.6 & 5.1 & 27.9 & 3.5 & 31.8 & 0.0 \\
\hline \multirow{3}{*}{ France } & Low-market & 1.8 & -0.1 & 2.3 & 0.6 & 2.3 & 0.4 & 1.9 & -0.6 & 1.3 & -0.5 \\
\hline & Mid-market & 2.4 & 0.5 & 3.9 & -2.7 & 1.4 & 0.9 & 2.6 & -0.5 & 1.8 & 0.1 \\
\hline & Up-market & 4.5 & -0.5 & 5.0 & 1.1 & 1.8 & 0.2 & 4.0 & -0.2 & 3.6 & -0.7 \\
\hline \multirow{3}{*}{ Germany } & Low-market & 1.8 & 0.3 & 5.0 & 1.0 & 1.8 & -0.2 & 2.9 & -1.0 & 3.2 & -0.1 \\
\hline & Mid-market & 2.5 & -0.3 & 10.9 & 1.8 & 1.8 & 0.7 & 9.2 & 2.3 & 5.0 & 0.6 \\
\hline & Up-market & 13.6 & 1.3 & 13.0 & 1.5 & 3.1 & 1.2 & 10.9 & 1.1 & 8.4 & -2.5 \\
\hline \multirow{3}{*}{ Italy } & Low-market & 0.9 & -0.8 & 4.0 & -0.9 & 0.6 & 0.0 & 2.8 & -1.0 & 2.0 & -0.4 \\
\hline & Mid-market & 2.5 & -0.7 & 5.3 & 1.9 & 0.3 & 0.2 & 2.5 & 0.0 & 2.2 & 0.1 \\
\hline & Up-market & 5.7 & 0.7 & 2.8 & 1.2 & 0.8 & 0.2 & 1.8 & 0.1 & 4.2 & 0.1 \\
\hline \multirow{3}{*}{ Poland } & Low-market & 0.4 & 0.0 & 0.5 & 0.3 & 0.6 & 0.5 & 0.2 & 0.1 & 0.4 & 0.0 \\
\hline & Mid-market & 0.3 & 0.2 & 0.1 & 0.1 & 0.1 & 0.1 & 0.3 & 0.2 & 0.3 & 0.1 \\
\hline & Up-market & 0.1 & 0.1 & 0.1 & 0.1 & 0.1 & 0.1 & 0.1 & 0.1 & 0.1 & 0.1 \\
\hline \multirow{3}{*}{ Spain } & Low-market & 0.8 & 0.0 & 0.7 & 0.0 & 0.4 & 0.2 & 0.8 & 0.1 & 1.1 & 0.1 \\
\hline & Mid-market & 1.4 & 0.3 & 1.0 & 0.2 & 0.1 & 0.0 & 0.8 & 0.2 & 0.9 & 0.0 \\
\hline & Up-market & 1.2 & 0.1 & 0.4 & -0.1 & 0.8 & 0.4 & 0.4 & 0.2 & 1.0 & 0.2 \\
\hline \multirow{3}{*}{ UK } & Low-market & 0.9 & -0.3 & 1.4 & -1.5 & 1.2 & 0.6 & 1.7 & -1.5 & 1.0 & -0.8 \\
\hline & Mid-market & 4.0 & 1.6 & 3.2 & -0.6 & 1.1 & 0.3 & 3.5 & 0.3 & 1.8 & -0.3 \\
\hline & Up-market & 4.4 & -0.1 & 3.0 & -0.4 & 2.4 & 1.1 & 4.7 & 0.6 & 3.4 & -0.4 \\
\hline \multirow{3}{*}{ Japan } & Low-market & 6.1 & 2.2 & 11.5 & -4.7 & 2.3 & 1.8 & 8.2 & -10.7 & 4.0 & -0.6 \\
\hline & Mid-market & 14.1 & -5.3 & 16.1 & -6.4 & 1.1 & 0.9 & 20.5 & -13.0 & 6.7 & -2.3 \\
\hline & Up-market & 10.5 & -2.1 & 15.5 & -14.7 & 0.8 & -0.2 & 25.1 & -6.0 & 13.7 & -5.3 \\
\hline \multirow{3}{*}{ Korea } & Low-market & 4.8 & 0.4 & 6.5 & -0.9 & 0.5 & 0.4 & 5.4 & 0.2 & 4.7 & -0.5 \\
\hline & Mid-market & 1.5 & -2.0 & 6.8 & 3.8 & 0.4 & 0.1 & 6.2 & 3.4 & 5.6 & 1.0 \\
\hline & Up-market & 1.6 & -1.2 & 7.0 & 6.1 & 0.7 & -0.5 & 3.1 & -6.1 & 1.9 & -1.1 \\
\hline \multirow{3}{*}{ Russia } & Low-market & 0.6 & 0.1 & 1.0 & 0.8 & 8.2 & 3.2 & 0.6 & 0.4 & 4.2 & 0.6 \\
\hline & Mid-market & 0.3 & 0.1 & 1.3 & 1.2 & 2.1 & 0.6 & 0.3 & 0.2 & 4.0 & 0.6 \\
\hline & Up-market & 0.3 & -0.2 & 0.2 & 0.2 & 1.2 & 0.3 & 0.3 & 0.3 & 0.7 & 0.5 \\
\hline \multirow{3}{*}{ India } & Low-market & 2.5 & 0.1 & 0.6 & 0.2 & 2.8 & 1.3 & 0.8 & 0.2 & 2.4 & 0.8 \\
\hline & Mid-market & 1.9 & 0.5 & 0.2 & 0.1 & 0.6 & 0.1 & 0.4 & 0.1 & 1.4 & 0.4 \\
\hline & Up-market & 1.1 & 0.1 & 0.1 & 0.1 & 0.9 & 0.3 & 0.2 & 0.0 & 0.9 & 0.2 \\
\hline \multirow{3}{*}{ Ukraine } & Low-market & 0.3 & 0.2 & 0.3 & 0.3 & 1.2 & 0.5 & 0.2 & 0.2 & 1.0 & 0.2 \\
\hline & Mid-market & 0.1 & 0.1 & 0.1 & 0.1 & 0.8 & 0.8 & 0.1 & 0.1 & 0.7 & 0.5 \\
\hline & Up-market & 0.0 & 0.0 & 0.0 & 0.0 & 0.4 & 0.4 & 0.0 & 0.0 & 0.2 & 0.1 \\
\hline \multirow{3}{*}{ USA } & Low-market & 7.9 & -3.0 & 14.5 & -2.4 & 14.2 & -11.6 & 15.9 & -3.3 & 12.1 & -4.3 \\
\hline & Mid-market & 10.2 & -1.3 & 13.9 & -7.6 & 36.2 & -0.2 & 14.4 & -3.9 & 11.3 & -4.5 \\
\hline & Up-market & 10.7 & -0.8 & 19.7 & -2.7 & 31.0 & -1.7 & 20.9 & 0.2 & 20.9 & 5.3 \\
\hline & Low-market & 31.4 & 3.7 & 24.4 & 6.5 & 6.1 & 1.2 & 27.0 & 11.9 & 21.8 & 4.3 \\
\hline Chinese world & Mid-market & 17.7 & 4.5 & 12.2 & 9.2 & 5.6 & 3.4 & 16.0 & 13.4 & 7.9 & 2.4 \\
\hline & Up-market & 9.6 & 0.2 & 4.9 & 2.9 & 5.0 & 0.0 & 4.5 & 3.0 & 5.7 & 1.8 \\
\hline & Low-market & 28.5 & 5.5 & 18.3 & 10.5 & 5.0 & 1.0 & 20.1 & 13.7 & 14.4 & 5.6 \\
\hline China & Mid-market & 14.0 & 6.3 & 8.9 & 7.6 & 5.1 & 3.4 & 7.0 & 6.1 & 4.7 & 1.5 \\
\hline & Up-market & 6.3 & 1.4 & 2.3 & 1.5 & 3.1 & -0.5 & 2.1 & 1.7 & 3.1 & 1.1 \\
\hline & Low-market & 1.7 & -0.6 & 1.7 & 0.0 & 0.6 & 0.3 & 2.4 & 0.3 & 1.5 & 0.0 \\
\hline Hong Kong & Mid-market & 2.1 & -1.2 & 1.2 & 0.7 & 0.3 & 0.0 & 2.5 & 1.7 & 1.2 & 0.7 \\
\hline & Up-market & 2.3 & 0.4 & 0.4 & 0.2 & 1.3 & 1.1 & 0.8 & 0.3 & 1.7 & 1.2 \\
\hline
\end{tabular}


Cheptea, Gaulier, Sondjo and Zignago (2006), Study Report

\begin{tabular}{|c|c|c|c|c|c|c|c|c|c|c|c|}
\hline & & \multicolumn{2}{|c|}{ Consumption } & \multicolumn{2}{|c|}{ Capital } & \multicolumn{2}{|c|}{ Primary } & \multicolumn{2}{|c|}{$\begin{array}{l}\text { Parts and } \\
\text { components }\end{array}$} & \multicolumn{2}{|c|}{ Transformed } \\
\hline & & 2003 & $\Delta$ & 2003 & $\Delta$ & 2003 & $\Delta$ & 2003 & $\Delta$ & 2003 & $\Delta$ \\
\hline \multirow{3}{*}{ Mediterranean } & Low-market & 2.6 & 0.2 & 1.0 & 0.8 & 1.1 & 0.3 & 1.1 & 0.6 & 2.2 & 0.6 \\
\hline & Mid-market & 4.0 & 0.6 & 0.6 & 0.5 & 0.8 & 0.5 & 0.5 & 0.1 & 1.4 & -0.1 \\
\hline & Up-market & 3.3 & 0.6 & 0.4 & 0.4 & 1.9 & -0.6 & 0.3 & 0.2 & 1.0 & 0.2 \\
\hline \multirow{3}{*}{ GCC } & Low-market & 0.5 & 0.0 & 0.4 & 0.2 & 0.3 & -0.1 & 0.3 & 0.1 & 1.9 & 0.5 \\
\hline & Mid-market & 0.3 & 0.1 & 0.4 & 0.3 & 0.5 & 0.0 & 0.6 & 0.5 & 1.1 & 0.2 \\
\hline & Up-market & 0.2 & -0.2 & 0.3 & 0.2 & 0.7 & 0.0 & 0.2 & 0.1 & 0.3 & 0.1 \\
\hline \multirow{3}{*}{ Mercosur } & Low-market & 2.7 & -0.1 & 1.3 & 0.2 & 14.8 & 6.7 & 1.7 & -0.5 & 4.0 & 0.0 \\
\hline & Mid-market & 2.0 & -0.4 & 2.8 & 1.7 & 14.7 & 5.7 & 1.2 & 0.3 & 5.6 & 0.4 \\
\hline & Up-market & 0.8 & -0.5 & 0.9 & 0.5 & 1.2 & -0.4 & 0.4 & 0.0 & 1.2 & -0.2 \\
\hline \multirow{3}{*}{ Brazil } & Low-market & 1.8 & 0.3 & 1.1 & 0.2 & 8.8 & 6.1 & 1.5 & -0.4 & 2.7 & 0.1 \\
\hline & Mid-market & 1.5 & 0.0 & 2.7 & 2.0 & 8.4 & 2.4 & 1.1 & 0.4 & 3.6 & -0.4 \\
\hline & Up-market & 0.6 & -0.1 & 0.8 & 0.5 & 0.6 & -0.4 & 0.3 & 0.1 & 0.8 & -0.2 \\
\hline \multirow{3}{*}{ ASEAN } & Low-market & 6.7 & -2.4 & 6.5 & -7.4 & 9.2 & -2.1 & 9.0 & -3.1 & 7.5 & -0.2 \\
\hline & Mid-market & 8.5 & -1.8 & 4.9 & -8.1 & 9.6 & -4.2 & 7.9 & -0.3 & 7.7 & 1.2 \\
\hline & Up-market & 5.3 & -2.7 & 2.9 & -1.6 & 4.4 & -2.1 & 8.7 & 3.7 & 4.5 & 0.0 \\
\hline \multirow{3}{*}{ RoW } & Low-market & 24.7 & 0.5 & 13.7 & 5.9 & 27.7 & -5.1 & 16.7 & 8.4 & 20.5 & 0.2 \\
\hline & Mid-market & 20.8 & 2.1 & 7.9 & 0.0 & 20.6 & -8.8 & 8.5 & -3.3 & 28.7 & -0.8 \\
\hline & Up-market & 18.6 & 4.0 & 16.3 & 3.6 & 36.3 & -0.6 & 8.3 & 1.1 & 17.1 & -1.5 \\
\hline
\end{tabular}

Table 33: CTB by quality in 2003 and 1995 (EU25)

\begin{tabular}{|c|c|c|c|c|c|c|c|c|c|c|}
\hline & \multicolumn{5}{|c|}{1995} & \multicolumn{5}{|c|}{2003} \\
\hline & $\begin{array}{l}\text { Low- } \\
\text { market }\end{array}$ & $\begin{array}{r}\text { Mid- } \\
\text { market }\end{array}$ & $\begin{array}{r}\text { Up- } \\
\text { market }\end{array}$ & $\mathrm{nc}$ & $\begin{array}{c}\text { Degree } \\
\text { of speci- } \\
\text { alisation }\end{array}$ & $\begin{array}{l}\text { Low- } \\
\text { market }\end{array}$ & $\begin{array}{r}\text { Mid-market } \\
\text { market }\end{array}$ & $\begin{array}{r}\text { Up- } \\
\text { market }\end{array}$ & $\mathrm{nc}$ & $\begin{array}{l}\text { Degree } \\
\text { of speci- } \\
\text { alisation }\end{array}$ \\
\hline EU25 & -36.5 & -20.8 & 61.0 & -3.7 & 52.3 & -56.6 & -15.8 & 75.8 & -3.4 & 67.8 \\
\hline Austria & -57.3 & -14.4 & 69.9 & 1.8 & 64.7 & -17.7 & -32.6 & 52.9 & -2.6 & 45.7 \\
\hline Belgium \& Lux. & -45.5 & 0.4 & 31.3 & 13.8 & 38.6 & -42.2 & -15.6 & 22.6 & 35.3 & 32.6 \\
\hline Cyprus & -26.0 & 0.1 & -14.8 & 40.7 & 13.1 & 29.5 & -54.6 & -12.8 & 37.9 & 42.0 \\
\hline Czech Republic & 45.0 & -16.4 & -25.9 & -2.7 & 38.5 & -8.9 & 4.3 & 2.3 & 2.3 & 7.1 \\
\hline Denmark & -35.5 & -48.5 & 79.3 & 4.7 & 70.3 & -55.1 & -18.0 & 69.9 & 3.2 & 64.2 \\
\hline Estonia & -41.3 & 14.3 & 31.0 & -4.0 & 37.8 & 49.8 & -23.9 & 18.5 & -44.4 & 37.0 \\
\hline Finland & -30.0 & 1.7 & 15.3 & 13.0 & 23.2 & -33.9 & 0.6 & 17.5 & 15.8 & 26.2 \\
\hline France & -24.1 & -35.4 & 66.2 & -6.7 & 55.7 & -36.6 & -32.1 & 72.3 & -3.7 & 61.6 \\
\hline Germany & -48.0 & -20.5 & 72.4 & -3.9 & 63.1 & -80.3 & -1.8 & 84.3 & -2.2 & 82.3 \\
\hline Greece & 32.7 & -21.8 & -9.0 & -2.0 & 28.5 & 57.7 & 12.9 & -71.1 & 0.6 & 65.4 \\
\hline Hungary & 32.3 & -3.4 & -26.8 & -2.2 & 29.7 & 3.0 & -25.8 & 20.3 & 2.5 & 23.3 \\
\hline Ireland & -54.5 & -81.4 & 128.1 & 7.9 & 114.0 & -74.5 & -56.5 & 145.3 & -14.3 & 122.0 \\
\hline Italy & 11.2 & -40.4 & 23.7 & 5.5 & 34.0 & -31.6 & -55.0 & 84.1 & 2.4 & 74.5 \\
\hline Latvia & 12.4 & 23.8 & -20.9 & -15.4 & 23.2 & -14.0 & -14.2 & 25.3 & 2.9 & 22.7 \\
\hline Lithuania & -45.2 & 27.0 & 17.9 & 0.3 & 39.3 & -17.5 & 39.3 & -24.7 & 3.0 & 35.0 \\
\hline Malta & -146.9 & -32.5 & 139.4 & 40.0 & 144.1 & -42.6 & -90.9 & -78.0 & 211.5 & 25.0 \\
\hline Netherlands & -64.7 & 30.7 & 38.0 & -4.0 & 57.3 & -57.8 & 0.5 & 62.9 & -5.6 & 60.4 \\
\hline Poland & 92.9 & -21.4 & -70.7 & -0.8 & 84.0 & 15.8 & 3.4 & -24.2 & 5.0 & 20.4 \\
\hline Portugal & -26.4 & -36.5 & 63.4 & -0.5 & 55.0 & -18.4 & -49.2 & 65.2 & 2.4 & 59.2 \\
\hline Slovakia & 65.0 & 16.6 & -69.7 & -11.9 & 68.2 & -77.5 & 128.2 & -50.1 & -0.7 & 111.7 \\
\hline Slovenia & 38.5 & 13.6 & -45.5 & -6.6 & 43.1 & 46.8 & -49.6 & 1.9 & 0.9 & 48.2 \\
\hline Spain & 9.8 & -24.8 & 17.7 & -2.7 & 22.6 & -18.1 & -5.9 & 29.5 & -5.4 & 24.7 \\
\hline Sweden & -38.9 & -10.5 & 54.5 & -5.1 & 47.8 & -46.2 & -19.1 & 65.2 & 0.1 & 58.1 \\
\hline United Kingdom & -50.5 & -21.7 & 73.8 & -1.6 & 65.1 & -65.5 & 0.0 & 58.5 & 7.0 & 62.1 \\
\hline
\end{tabular}


Figure 7: Evolution of CTB in Low-Market Products

Evolution of CTB in Low-Market products by industry - China

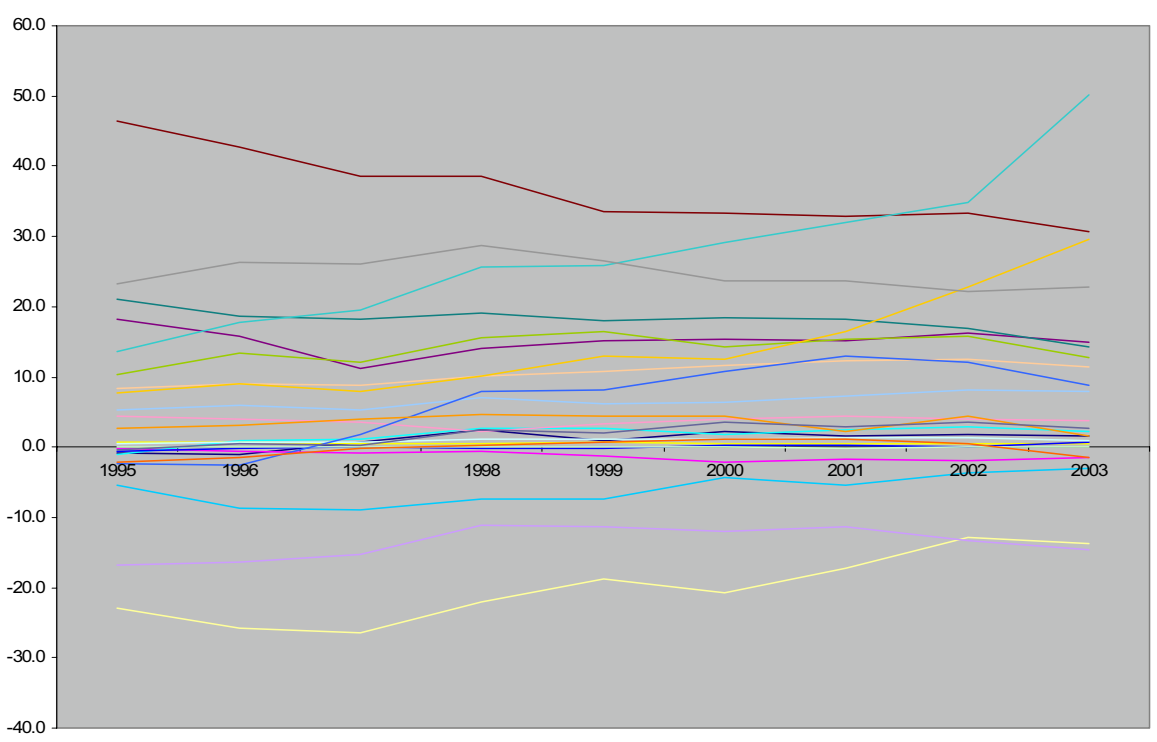

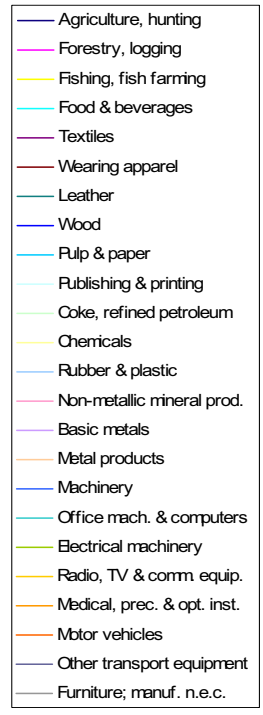

Evolution of CTB in Low-Market products by industry - Korea

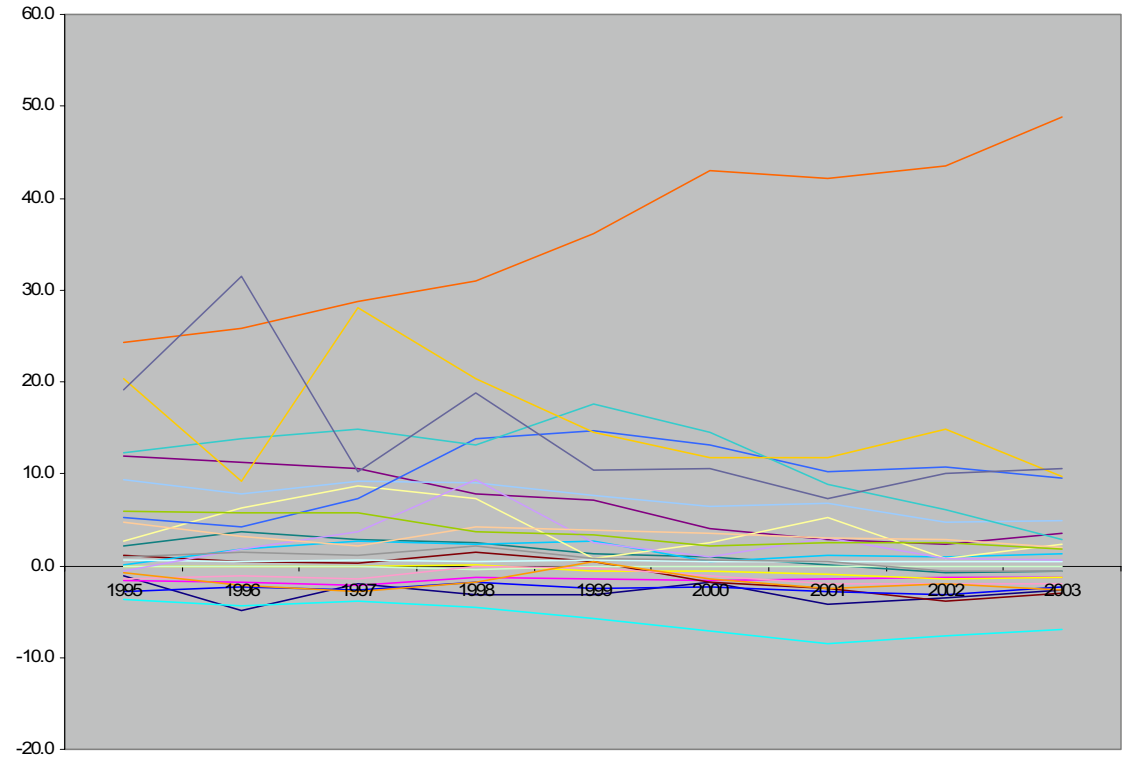

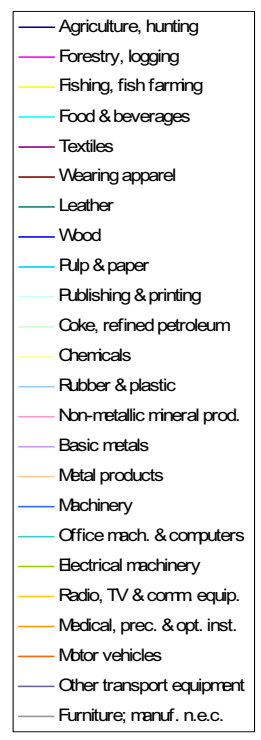


Cheptea, Gaulier, Sondjo and Zignago (2006), Study Report

Table 34: CTB by production stages and quality

\begin{tabular}{|c|c|c|c|c|c|c|c|c|}
\hline & \multicolumn{8}{|c|}{1995} \\
\hline & Quality & EU25 & USA & Japan & Korea & Russia & India & China \\
\hline \multirow[t]{5}{*}{ Consumption } & all & -0.8 & -75.2 & -96.3 & -211.5 & 166.6 & 55.8 & 208.0 \\
\hline & nc & -1.85 & 1.54 & -7.6 & -5.45 & 9.99 & 0.28 & 4.21 \\
\hline & Low-market & -20.38 & -43.5 & -22.77 & -104.98 & 97.45 & 33.64 & 161.1 \\
\hline & Mid-market & -16.45 & -10.92 & -4.88 & -55.14 & 46.89 & 21.99 & 29.36 \\
\hline & Up-market & 37.93 & -22.35 & -61.04 & -45.89 & 12.3 & -0.16 & 13.31 \\
\hline \multirow[t]{5}{*}{ Capital } & all & 18.1 & 19.7 & 59.5 & -75.3 & -78.1 & -21.3 & -50.0 \\
\hline & nc & 0.48 & 4.87 & 0.77 & -2.05 & -3.74 & 0.02 & -4.98 \\
\hline & Low-market & -0.72 & -8.75 & 15.87 & -16.42 & -31.37 & 47.86 & 19.07 \\
\hline & Mid-market & 3.08 & 9.24 & 17.45 & -22.2 & -17.88 & -16.51 & -20.81 \\
\hline & Up-market & 15.27 & 14.31 & 25.38 & -34.63 & -25.14 & -52.71 & -43.25 \\
\hline \multirow[t]{5}{*}{ Primary } & all & -16.7 & 23.4 & -25.0 & 43.7 & -56.8 & -28.3 & -15.9 \\
\hline & $\mathrm{nc}$ & -2.52 & -0.54 & -0.23 & 5.43 & -47.01 & -0.35 & 0.08 \\
\hline & Low-market & -3.57 & 2.51 & -5.12 & 29.41 & -0.49 & -2.71 & -8.13 \\
\hline & Mid-market & -7.6 & 17.34 & -10.78 & 6.15 & -5.61 & -21.86 & -8.36 \\
\hline & Up-market & -2.96 & 4.06 & -8.86 & 2.71 & -3.7 & -3.41 & 0.5 \\
\hline \multirow[t]{5}{*}{ Parts and components } & all & -13.4 & 17.2 & 89.5 & -27.9 & -67.1 & 22.0 & -43.2 \\
\hline & nc & 0.53 & -0.8 & 10.09 & -3.78 & -1.17 & -0.02 & -3.48 \\
\hline & Low-market & -8.51 & 10.23 & 10.63 & -4.0 & -21.59 & 11.05 & -16.3 \\
\hline & Mid-market & -0.11 & -0.16 & 34.14 & -7.98 & -17.14 & -6.13 & -7.76 \\
\hline & Up-market & -5.28 & 7.89 & 34.61 & -12.16 & -27.2 & 17.1 & -15.61 \\
\hline \multirow[t]{7}{*}{ Transformed } & all & 12.7 & 15.0 & -27.7 & 271.0 & 35.4 & -28.1 & -99.0 \\
\hline & nc & -0.34 & -3.82 & -6.35 & 16.46 & 82.96 & -0.88 & -0.83 \\
\hline & Low-market & -3.29 & 3.06 & -14.58 & 155.27 & 5.86 & 18.58 & -46.02 \\
\hline & Mid-market & 0.27 & 9.63 & -12.04 & 121.74 & -35.82 & -16.47 & -33.72 \\
\hline & Up-market & 16.04 & 6.16 & 5.32 & -22.47 & -17.59 & -29.33 & -18.38 \\
\hline & \multicolumn{8}{|c|}{2003} \\
\hline & Quality & EU25 & USA & Japan & Korea & Russia & India & China \\
\hline \multirow[t]{5}{*}{ Consumption } & all & -11.3 & -97.2 & -54.5 & 25.8 & -139.7 & 156.4 & 162.5 \\
\hline & & -0.6 & -3.7 & -5.7 & 1.1 & -2.2 & 16.6 & 3.6 \\
\hline & Low-market & -30.7 & -39.1 & -20.9 & 31.8 & -73.4 & 75.7 & 120.0 \\
\hline & Mid-market & -14.9 & -25.9 & 15.8 & 1.2 & -27.8 & 43.7 & 28.5 \\
\hline & Up-market & 34.9 & -28.4 & -43.8 & -8.3 & -36.5 & 20.3 & 10.4 \\
\hline \multirow[t]{5}{*}{ Capital } & all & 3.1 & 6.5 & 40.7 & 49.9 & -60.7 & -78.2 & 4.6 \\
\hline & & -3.8 & 4.6 & -0.2 & 0.2 & 1.7 & -8.8 & -2.7 \\
\hline & Low-market & -6.2 & -14.4 & 10.8 & 24.2 & -14.6 & -24.2 & 48.4 \\
\hline & Mid-market & 1.9 & 0.6 & 7.9 & 5.0 & -25.3 & -12.7 & 1.0 \\
\hline & Up-market & 11.2 & 15.8 & 22.2 & 20.5 & -22.6 & -32.5 & -42.1 \\
\hline \multirow[t]{5}{*}{ Primary } & all & -8.4 & 19.7 & -22.0 & -22.2 & 36.5 & -58.7 & -20.5 \\
\hline & nc & 0.0 & -0.1 & -2.8 & -0.4 & 7.2 & -56.8 & -1.4 \\
\hline & Low-market & -2.0 & 1.6 & -1.2 & -4.1 & 18.1 & 4.4 & -4.9 \\
\hline & Mid-market & -5.2 & 14.9 & -12.7 & -15.1 & 9.6 & -2.8 & -12.1 \\
\hline & Up-market & -1.1 & 3.3 & -5.3 & -2.6 & 1.5 & -3.5 & -2.0 \\
\hline \multirow[t]{5}{*}{ Parts and components } & all & -1.1 & 49.9 & 53.5 & -12.2 & -16.1 & -37.8 & -67.4 \\
\hline & nc & 0.7 & 24.1 & 0.7 & 0.0 & -0.1 & -3.9 & -36.0 \\
\hline & Low-market & -12.9 & 2.1 & 9.3 & 17.3 & -4.3 & -5.5 & 31.1 \\
\hline & Mid-market & 2.2 & 7.1 & 23.5 & -1.8 & -9.8 & -10.3 & -25.0 \\
\hline & Up-market & 9.0 & 16.7 & 20.0 & -27.7 & -1.9 & -18.1 & -37.5 \\
\hline \multirow[t]{5}{*}{ Transformed } & all & 17.7 & 21.1 & -17.6 & -41.3 & 180.0 & 18.3 & -79.3 \\
\hline & nc & 0.4 & -3.1 & -2.3 & -1.2 & 6.4 & 60.4 & -0.4 \\
\hline & Low-market & -4.8 & 2.8 & -17.0 & 5.6 & 88.1 & 22.9 & -11.9 \\
\hline & Mid-market & 0.2 & 8.6 & -4.4 & -8.5 & 92.6 & -61.9 & -49.4 \\
\hline & Up-market & 21.9 & 12.8 & 6.0 & -37.2 & -7.0 & -3.2 & -17.6 \\
\hline
\end{tabular}

Note: nc stands for not classified. When quantities are not ayailable the breakdown by quality ranges in not possible. 
Table 35: Decomposition of market share growth, exports performance, and the sectoral structure effect by the technological component of traded products 1995-2003, (in \%)

\begin{tabular}{|c|c|c|c|c|c|c|c|c|}
\hline \multicolumn{9}{|c|}{ Decomposition of market share growth } \\
\hline Product type & EU25 & EU15 & Brazil & China & Japan & Russia & India & USA \\
\hline & \multicolumn{8}{|c|}{ Volume } \\
\hline High technology & -2.3 & -2.5 & 2.4 & 15.8 & -10.1 & -0.8 & 3.2 & 1.6 \\
\hline \multirow[t]{2}{*}{ Others } & -12.9 & -14.3 & 11.0 & 47.3 & -25.1 & -48.8 & 22.0 & -4.6 \\
\hline & \multicolumn{8}{|c|}{ Value } \\
\hline High technology & -1.0 & 1.1 & 5.9 & 16.4 & -8.0 & 3.6 & 1.1 & -1.3 \\
\hline Others & -1.4 & -5.3 & 1.0 & 49.6 & -23.5 & -45.4 & 18.1 & -12.1 \\
\hline \multicolumn{9}{|c|}{ Decomposition of exports performance } \\
\hline \multirow[t]{2}{*}{ Product type } & EU25 & EU15 & Brazil & China & Japan & Russia & India & USA \\
\hline & \multicolumn{8}{|c|}{ Volume } \\
\hline High technology & -4.0 & -3.6 & 3.7 & 13.6 & -7.0 & -0.9 & 3.0 & -8.6 \\
\hline \multirow[t]{2}{*}{ Others } & -17.1 & -19.3 & 38.4 & 101.2 & -33.8 & -26.4 & 56.9 & -34.4 \\
\hline & \multicolumn{8}{|c|}{ Value } \\
\hline High technology & -3.6 & -2.4 & 3.4 & 13.5 & -7.4 & -0.7 & 2.7 & -7.9 \\
\hline Others & -9.3 & -12.6 & 37.7 & 102.7 & -36.1 & -22.6 & 51.9 & -30.7 \\
\hline \multicolumn{9}{|c|}{ Decomposition of the sectoral structure effect } \\
\hline \multirow[t]{2}{*}{ Product type } & EU25 & EU15 & Brazil & China & Japan & Russia & India & USA \\
\hline & \multicolumn{8}{|c|}{ Volume } \\
\hline High technology & 4.7 & 4.8 & 0.0 & 2.2 & 1.7 & -0.1 & 0.6 & 7.5 \\
\hline \multirow[t]{2}{*}{ Others } & 3.6 & 4.0 & -18.8 & -32.3 & 9.9 & -27.3 & -32.7 & 4.9 \\
\hline & \multicolumn{8}{|c|}{ Value } \\
\hline High technology & 5.6 & 5.7 & -0.7 & 1.1 & 1.3 & -0.1 & 0.3 & 8.5 \\
\hline Others & 6.5 & 7.0 & -23.7 & -35.4 & 10.7 & -32.2 & -36.0 & 7.9 \\
\hline
\end{tabular}


Table 36: Decomposition of market share growth, exports performance, and the sectoral structure effect by the technological component and the quality of traded products 1995-2003 (in \%)

\begin{tabular}{|c|c|c|c|c|c|c|c|c|}
\hline \multicolumn{9}{|c|}{ Decomposition of market share growth } \\
\hline Product type & EU25 & EU15 & Brazil & China & Japan & Russia & India & USA \\
\hline & \multicolumn{8}{|c|}{ Volume } \\
\hline High tech Low-market & 0.0 & -0.6 & 0.3 & 13.3 & -0.5 & 1.1 & 1.6 & 0.9 \\
\hline High tech Mid-market & 0.1 & 0.0 & -0.2 & 1.0 & -1.0 & 0.8 & 0.1 & 0.1 \\
\hline High tech Up-market & -2.4 & -1.8 & 2.4 & 1.5 & -8.6 & -2.7 & 1.5 & 0.5 \\
\hline Others Low-market & -0.4 & -4.0 & 8.9 & 41.4 & -5.2 & -18.2 & 14.6 & 3.8 \\
\hline Others Mid-market & -4.8 & -3.9 & 0.0 & 0.3 & -1.0 & -13.1 & 3.1 & -3.2 \\
\hline \multirow[t]{2}{*}{ Others Up-market } & -7.7 & -6.4 & 2.1 & 5.6 & -19.0 & -17.5 & 4.3 & -5.1 \\
\hline & \multicolumn{8}{|c|}{ Value } \\
\hline High tech Low-market & -0.4 & 0.2 & 1.4 & 13.6 & -1.3 & 3.2 & 0.7 & -0.9 \\
\hline High tech Mid-market & -0.2 & 0.3 & -0.1 & 1.4 & -1.0 & 2.0 & -0.1 & -0.7 \\
\hline High tech Up-market & -0.4 & 0.6 & 4.6 & 1.3 & -5.7 & -1.5 & 0.5 & 0.2 \\
\hline Others Low-market & -1.2 & -1.9 & 2.9 & 39.2 & -6.3 & -18.0 & 12.5 & -3.3 \\
\hline Others Mid-market & 0.4 & -2.7 & -3.0 & 4.4 & -1.9 & -17.7 & 3.2 & -2.9 \\
\hline Others Up-market & -0.6 & -0.6 & 1.0 & 6.0 & -15.3 & -9.6 & 2.4 & -6.0 \\
\hline
\end{tabular}

Decomposition of exports performance

\begin{tabular}{|c|c|c|c|c|c|c|c|c|}
\hline Product type & EU25 & EU15 & Brazil & China & Japan & Russia & India & USA \\
\hline & \multicolumn{8}{|c|}{ Volume } \\
\hline High tech Low-market & -0.9 & -0.8 & 0.6 & 11.4 & -1.7 & -0.5 & 2.0 & -2.8 \\
\hline High tech Mid-market & -0.6 & -0.5 & 0.7 & 1.2 & -1.4 & -0.3 & 0.4 & -1.2 \\
\hline High tech Up-market & -2.5 & -2.2 & 2.4 & 1.0 & -3.9 & -0.1 & 0.6 & -4.6 \\
\hline Others Low-market & -2.9 & -4.9 & 18.1 & 71.4 & -6.9 & -14.7 & 32.4 & -11.0 \\
\hline Others Mid-market & -3.2 & -3.9 & 14.2 & 14.7 & -6.9 & -8.7 & 13.1 & -7.5 \\
\hline \multirow[t]{2}{*}{ Others Up-market } & -11.0 & -10.5 & 6.1 & 15.2 & -20.0 & -3.0 & 11.4 & -15.9 \\
\hline & \multicolumn{8}{|c|}{ Value } \\
\hline High tech Low-market & -0.5 & -0.5 & 0.6 & 11.4 & -1.9 & -0.5 & 1.8 & -2.7 \\
\hline High tech Mid-market & -0.6 & -0.4 & 0.6 & 1.1 & -1.5 & -0.2 & 0.4 & -1.0 \\
\hline High tech Up-market & -2.5 & -1.5 & 2.3 & 1.0 & -4.0 & 0.0 & 0.5 & -4.2 \\
\hline Others Low-market & 1.6 & -2.9 & 17.2 & 72.4 & -7.6 & -13.1 & 29.6 & -9.8 \\
\hline Others Mid-market & -1.7 & -2.6 & 14.5 & 14.9 & -7.9 & -7.0 & 12.0 & -6.5 \\
\hline Others Up-market & -9.3 & -7.1 & 6.0 & 15.4 & -20.6 & -2.5 & 10.3 & -14.4 \\
\hline
\end{tabular}

Decomposition of the sectoral structure effect

\begin{tabular}{lrrrrrrrr} 
Product type & EU25 & EU15 & Brazil & China & Japan & Russia & India & USA \\
\hline \hline & & \multicolumn{7}{c}{ Volume } \\
\hline High tech Low-market & 1.1 & 1.1 & 0.3 & 1.6 & 1.7 & 0.1 & 0.2 & 2.4 \\
High tech Mid-market & 0.8 & 0.8 & 0.2 & 0.3 & 1.1 & 0.7 & 0.1 & 1.0 \\
High tech Up-market & 2.8 & 2.9 & -0.6 & 0.4 & -1.1 & -0.8 & 0.3 & 4.1 \\
Others Low-market & 0.5 & 0.6 & -7.6 & -18.2 & 2.8 & -13.2 & -17.9 & 3.3 \\
Others Mid-market & -0.1 & 0.0 & -9.9 & -8.0 & 2.8 & -7.8 & -9.4 & -0.7 \\
Others Up-market & 3.2 & 3.3 & -1.3 & -6.1 & 4.2 & -6.3 & -5.4 & 2.3 \\
\hline & & & & & & & & \\
\hline High tech Low-market & 1.3 & 1.4 & 0.3 & 0.7 & 1.1 & 0.4 & 0.1 & 2.4 \\
High tech Mid-market & 0.9 & 1.0 & -0.5 & 0.2 & 0.9 & 0.2 & 0.1 & 1.1 \\
High tech Up-market & 3.3 & 3.4 & -0.6 & 0.2 & -0.7 & -0.7 & 0.1 & 5.0 \\
Others Low-market & 1.3 & 1.4 & -9.0 & -22.7 & 2.9 & -15.4 & -17.6 & 3.4 \\
Others Mid-market & 0.1 & 0.2 & -12.2 & -5.9 & 3.0 & -12.3 & -9.9 & 0.9 \\
Others Up-market & 5.1 & 5.4 & -2.5 & -6.8 & 4.8 & -4.5 & -8.5 & 3.7 \\
\hline \hline
\end{tabular}

